Prepared in cooperation with the U.S. Army Corps of Engineers

\title{
Behavior and Dam Passage of Juvenile Chinook Salmon and Juvenile Steelhead at Detroit Reservoir and Dam, Oregon, March 2012-February 2013
}

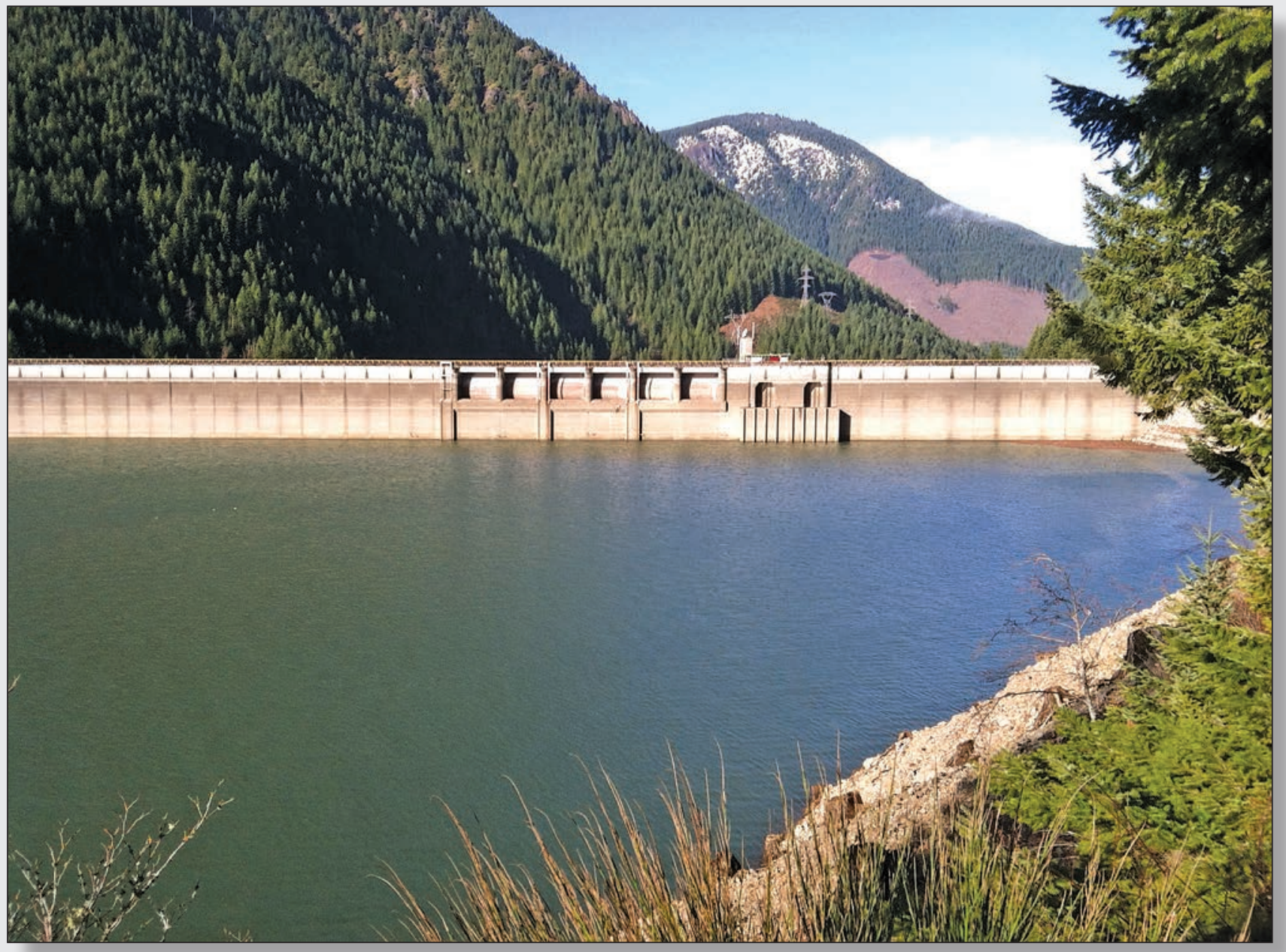

Open-File Report 2014-1144 
Cover: Photograph showing Detroit Dam and the forebay of Detroit Reservoir, Oregon.

Photograph by John Beeman, U.S. Geological Survey. 


\section{Behavior and Dam Passage of Juvenile Chinook Salmon and Juvenile Steelhead at Detroit Reservoir and Dam, Oregon, March 2012-February 2013}

By John W. Beeman, Hal C. Hansel, Amy C. Hansen, Scott D. Evans, Philip V. Haner, Tyson W. Hatton, Eric E. Kofoot, Jamie M. Sprando, and Collin D. Smith

Prepared in cooperation with the U.S. Army Corps of Engineers

Open-File Report 2014-1141

U.S. Department of the Interior

U.S. Geological Survey 


\section{U.S. Department of the Interior \\ SALLY JEWELL, Secretary}

\section{U.S. Geological Survey \\ Suzette M. Kimball, Acting Director}

U.S. Geological Survey, Reston, Virginia: 2014

For more information on the USGS-the Federal source for science about the Earth,

its natural and living resources, natural hazards, and the environment-visit

http://www.usgs.gov or call 1-888-ASK-USGS

For an overview of USGS information products, including maps, imagery, and publications, visit $h$ ttp://www.usgs.gov/pubprod

To order this and other USGS information products, visit $h$ ttp://store.usgs.gov

Suggested citation:

Beeman, J.W., Hansel, H. C., Hansen, A.C., Evans, S.D., Haner, P.V., Hatton, T.W., Kofoot, E.E., Sprando, J.M., and Smith, C.D., 2014, Behavior and dam passage of juvenile Chinook salmon and juvenile steelhead at Detroit Reservoir and Dam, Oregon, March 2012-February 2013: U.S. Geological Survey Open-File Report 2014-1144, 62 p., http://dx.doi.org/10.3133/ofr20141144.

ISSN 2331-1258 (online)

Any use of trade, firm, or product names is for descriptive purposes only and does not imply endorsement by the U.S. Government.

Although this information product, for the most part, is in the public domain, it also may contain copyrighted materials as noted in the text. Permission to reproduce copyrighted items must be secured from the copyright owner. 


\section{Contents}

Abstract

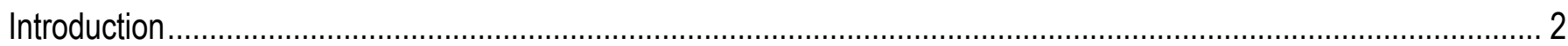

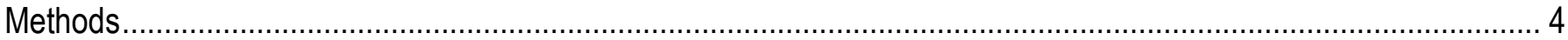

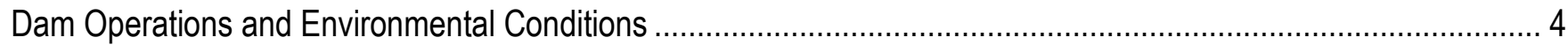

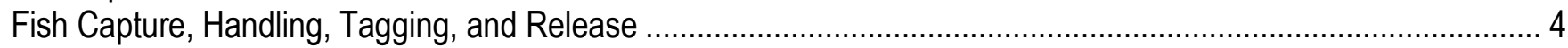

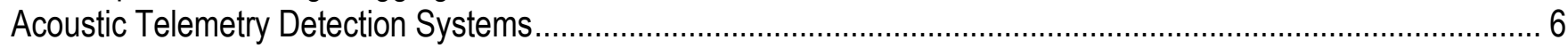

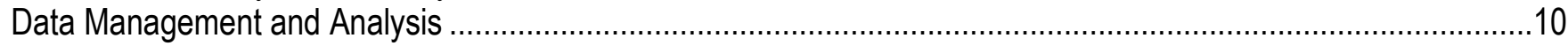

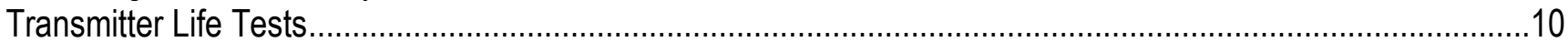

Removing False-Positive Records ................................................................................................

Estimating Fish Positions ................................................................................................................10

Movements within the Reservoir and Dam Passage ...............................................................................11

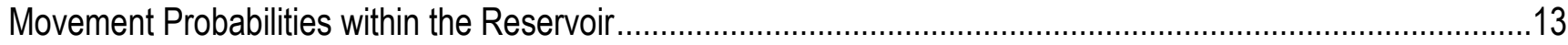

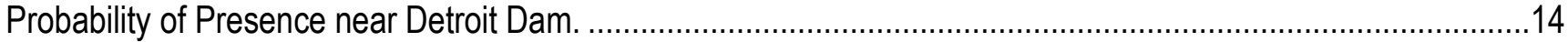

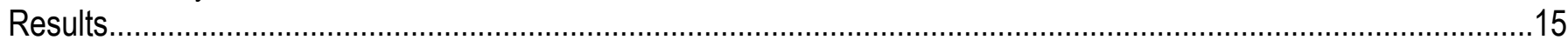

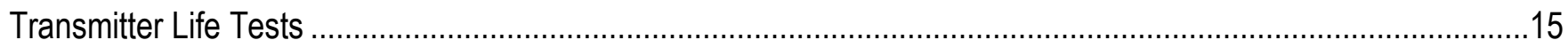

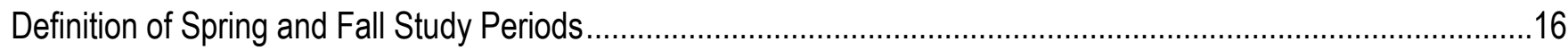

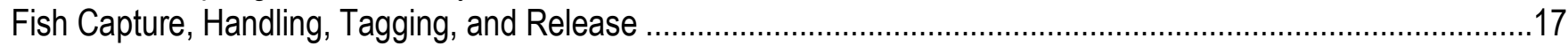

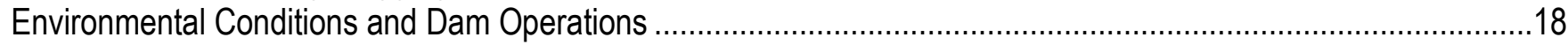

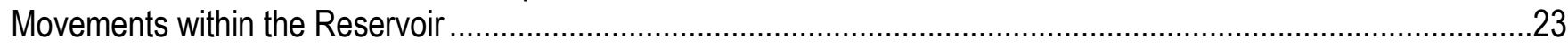

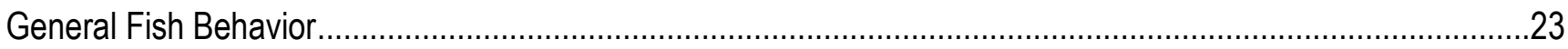

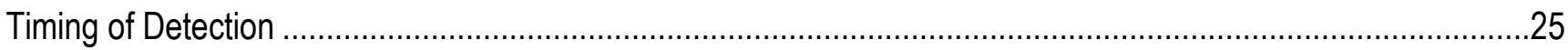

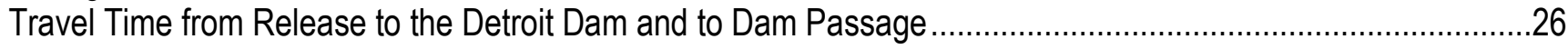

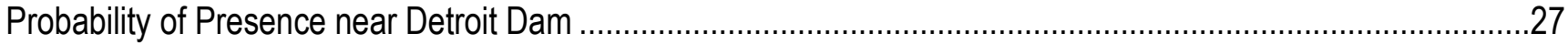

Movement Probabilities within the Reservoir.........................................................................................30

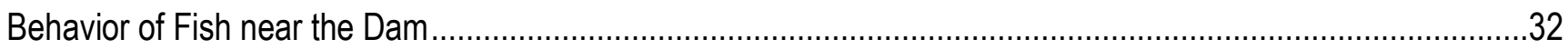

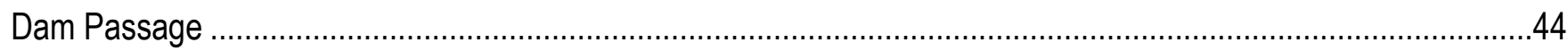

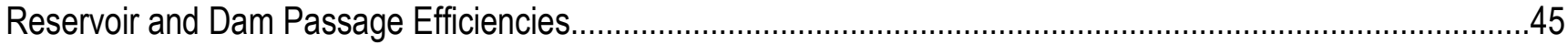

Effects of Selected Variables on Dam Passage Rates ............................................................................4

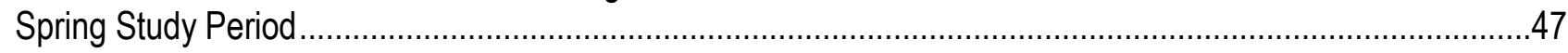

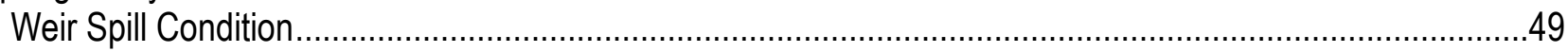

Powerhouse and Spillway Condition ...............................................................................................50

Spillway Only Condition without Weir Spill .......................................................................................51

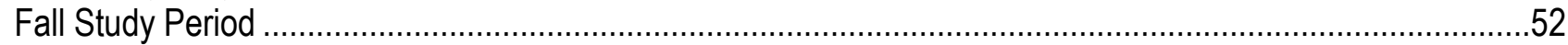

Powerhouse and Regulating Outlet Condition ................................................................................52

Effects of Selected Variables on Spillway Passage Rates …………….....................................................54

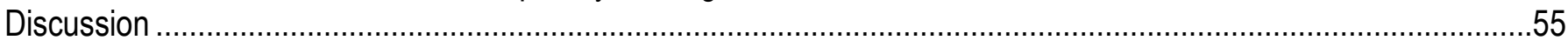

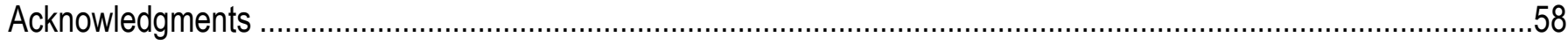

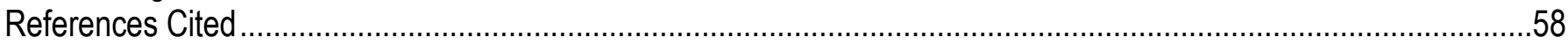

Appendix A. Results of Analyses of Movement Probabilities from Fish Released into Tributaries of

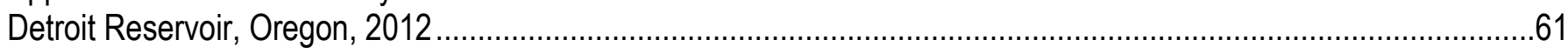




\section{Figures}

Figure 1. The Willamette River Basin showing dams and reservoirs of the Willamette Project, Oregon...................... 2

Figure 2. Elevation view of the upstream side of Detroit Dam showing outlet structures and elevations of full and minimum conservation pool....

Figure 3. Locations of autonomous acoustic receivers (yellow circles) deployed in Detroit Reservoir, Oregon, 2012. 7

Figure 4. Locations of cabled hydrophones (yellow circles) on floating platforms deployed in Detroit Reservoir,

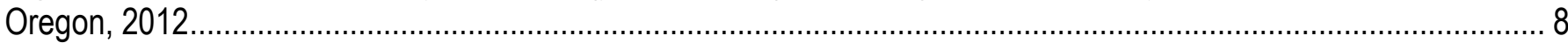

Figure 5. Schematic showing locations of cabled hydrophones at Detroit Dam, Oregon, 2012 …........................... 9

Figure 6. Schematic showing locations of underwater cabled hydrophones at Detroit Dam, Oregon, 2012 ............... 9

Figure 7. Graphs of transmitter extinction tests of the acoustic tag model used at Detroit Dam, Oregon, during the 2012 spring and fall study periods

Figure 8. Graphs showing percentage of live tags available, by date, in Detroit Reservoir. Oregon, 2012-13 .......... 16

Figure 9. Graphs showing mean daily discharge (Powerhouse, Spill, Regulating Outlet), forebay elevation, and average water temperature of the upper 20 feet of the forebay at Detroit Dam, Oregon, during the 2012 spring and fall study periods

Figure 10. Graph showing daily mean dam operations and environmental conditions at Detroit Reservoir, Oregon, from March 13, 2012, through February 21, 2013, when fish were detected in the study area. 21

Figure 11. Graphs showing percentage of fish not detected at Detroit Dam and Reservoir, Oregon, during the 2012 spring and fall study periods.....

Figure 12. Graphs showing movements of eight randomly selected juvenile Chinook salmon (left 2 columns) and juvenile steelhead (right 2 columns) in Detroit Reservoir, Oregon, during the 2012 spring study period. 24 Figure 13. Graphs showing movements of eight randomly selected juvenile Chinook salmon in Detroit Reservoir, Oregon, during the 2012 fall study period.

Figure 14. Graphs showing distributions of hourly arrival times of individual juvenile Chinook salmon and juvenile steelhead at detection arrays in Detroit Reservoir, Oregon, during the 2012 spring and fall study periods 26

Figure 15. Survival distribution plots of travel times (days) at Detroit Dam and Reservoir, Oregon, during the 2012 spring and fall study periods.

Figure 16. Graphs showing cumulative probabilities ( \pm 95-percent confidence interval) of being present at least once at reservoir arrays 1, 2, 4, 6 (forebay line), and arrays 7 and 8 at Detroit Dam for fish released into tributaries upstream of Detroit Reservoir, Oregon, during the 2012 spring and fall study periods.

Figure 17. Movement probabilities of juvenile Chinook salmon and juvenile steelhead in Detroit Reservoir, Oregon, during the 2012 spring study period.

Figure 18. Movement probabilities of juvenile Chinook salmon in Detroit Reservoir, Oregon, during the 2012 fall study period

Figure 19. Position estimates of randomly selected juvenile Chinook salmon within 105 meters of Detroit Dam, Oregon, during the 2012 spring study period.

Figure 20. Position estimates of randomly selected of juvenile steelhead within 105 meters of Detroit Dam, Oregon, during the 2012 spring study period.

Figure 21. Position estimates of randomly selected juvenile Chinook salmon within 105 meters of Detroit Dam, Oregon, during the 2012 fall study period when the pool elevation was less than $1,525 \mathrm{ft}$.

Figure 22. Distributions of the percent presence of juvenile Chinook salmon and juvenile steelhead in $10 \times 10$ meter cells along the x-y plane within 105 meters of Detroit Dam, Oregon, during the 2012 spring study period.

Figure 23. Distributions of the percent presence of juvenile Chinook salmon and juvenile steelhead in $20 \times 10$ meter cells along the $x-z$ plane at Detroit Dam, Oregon, during the 2012 spring study period . 
Figure 24. Distributions of the percent presence of juvenile Chinook salmon and juvenile steelhead in $10 \times 10$ meter cells along the $x-y$ plane within 105 meters of Detroit Dam, Oregon, during the 2012 fall study period.

Figure 25. Distributions of the percent presence of juvenile Chinook salmon and juvenile steelhead in $20 \times 10$ meter cells along the $x-z$ plane at Detroit Dam, Oregon, during the 2012 fall study period.....

Figure 26. Boxplots of the hourly depths in feet of juvenile Chinook salmon and juvenile steelhead with position estimates within 25 meters of Detroit Dam, Oregon, during the 2012 spring study period

Figure 27. Boxplots of the hourly depths in feet of juvenile Chinook salmon with position estimates within 25 meters of Detroit Dam, Oregon, during the 2012 fall study period.

Figure 28. Percentage of fish passing by hour at Detroit Dam, Oregon, during the 2012 spring and

fall study periods.

\section{Tables}

Table 1. Definitions of passage efficiency and effectiveness metrics

Table 2. Summary statistics of fork length and weight of acoustic- and PIT-tagged hatchery juvenile Chinook salmon and steelhead at Detroit Reservoir, Oregon, 2012

Table 3. Mean hourly summary statistics of dam operations and environmental conditions at Detroit Reservoir, Oregon, from March 13-August 21, 2012, when spring-released fish were detected in the study area

Table 4. Mean hourly summary statistics of dam operations and environmental conditions at Detroit Dam and Reservoir, Oregon, from September 12, 2012, through February 21, 2013, when fall-released fish were detected in the study area.

Table 5. Suite of models of detection probabilities for the analysis of presence probabilities of juvenile Chinook salmon and steelhead released into tributaries upstream of Detroit Reservoir, Oregon, during the 2012 spring and fall period.

Table 6. Suite of models used in estimation of presence probabilities of juvenile Chinook salmon released into tributaries upstream of Detroit Reservoir, Oregon, during the 2012 spring study period

Table 7. Suite of models used in estimation of presence probabilities of juvenile steelhead released into tributaries upstream of Detroit Reservoir, Oregon, during the 2012 spring study period

Table 8. Suite of models used in estimation of presence probabilities of juvenile Chinook salmon released into tributaries upstream of Detroit Reservoir, Oregon, during the 2012 fall study period

Table 9. Summary of the mean of the mean hourly depths of each fish with position estimates within 25 meters of Detroit Dam, Oregon, during the 2012 spring and fall study periods

Table 10. Seasonal passage metric estimates, standard errors, and lower and upper 95-percent confidence intervals from the study of acoustic-tagged juvenile salmonids at Detroit Dam, Oregon, 2012

Table 11. Dam passage efficiency estimates, standard errors, and lower and upper 95-percent confidence intervals, by pool elevation, from the study of acoustic-tagged juvenile salmonids at Detroit Dam, Oregon, 2012 ..... 47

Table 12. Summary of the frequency of use of various operating conditions and the numbers of tagged fish with three-dimensional position estimates within 25 meters of the dam passing during each condition at Detroit Dam, Oregon, during the 2012 spring and fall study periods

Table 13. Regression coefficients from analyses of the effects of selected variables on the rate of spillway passage of juvenile Chinook salmon within 25 meters of the upstream face of the area monitored at Detroit Dam, Oregon, during and 2-weeks after the weir spill condition in 2012 spring study period.....

Table 14. Regression coefficients from analyses of the effects of selected variables on the rate of dam passage of juvenile Chinook salmon and juvenile steelhead within 25 meters of the upstream face of Detroit Dam, Oregon, when the powerhouse and spillway were operated together during the 2012 spring study period. 
Table 15. Regression coefficients from analyses of the effects of selected variables on the rate of dam passage of fish within 25 meters of the upstream face of the area monitored at Detroit Dam, Oregon, during the 2012 spring study period during the powerhouse off, spillway on condition without weir spill

Table 16. Regression coefficients from analyses of the effects of selected variables on the rate of dam passage of juvenile Chinook salmon within 25 meters of the upstream face of the area monitored at Detroit Dam, Oregon, when the regulating outlet and powerhouse were operated together during the 2012 fall study period.

Table 17. Regression coefficients from analyses of the effects of selected variables on the rate of spillway passage of juvenile Chinook salmon within 25 meters of the upstream face of the area monitored at Detroit Dam, Oregon, during the 2012 spring study period.

\section{Conversion Factors and Datums}

\section{Conversion Factors}

Inch/Pound to SI

\begin{tabular}{lll}
\multicolumn{1}{c}{ Multiply } & \multicolumn{1}{c}{ By } & \multicolumn{1}{c}{ To obtain } \\
\hline foot $(\mathrm{ft})$ & 0.3048 & meter $(\mathrm{m})$ \\
cubic foot per second $\left(\mathrm{ft}^{3} / \mathrm{s}\right)$ & 0.02832 & cubic meter per second $\left(\mathrm{m}^{3} / \mathrm{s}\right)$ \\
\hline
\end{tabular}

SI to Inch/Pound

\begin{tabular}{lll}
\hline \multicolumn{1}{c}{ Multiply } & \multicolumn{1}{c}{ By } & \multicolumn{1}{c}{ To obtain } \\
\hline millimeter $(\mathrm{mm})$ & 0.03937 & inch (in.) \\
centimeter $(\mathrm{cm})$ & 0.3937 & inch (in.) \\
meter $(\mathrm{m})$ & 3.281 & foot (ft) \\
kilometer $(\mathrm{km})$ & 0.6214 & mile (mi) \\
kilometer $(\mathrm{km})$ & 0.5400 & mile, nautical (nmi) \\
meter per second $(\mathrm{m} / \mathrm{s})$ & 3.281 & foot per second (ft/s) \\
liter $(\mathrm{L})$ & 0.2642 & gallon (gal) \\
gram $(\mathrm{g})$ & 0.03527 & ounce, avoirdupois $(\mathrm{oz})$ \\
\hline
\end{tabular}

Temperature in degrees Celsius $\left({ }^{\circ} \mathrm{C}\right)$ may be converted to degrees Fahrenheit $\left({ }^{\circ} \mathrm{F}\right)$ as follows:

$$
{ }^{\circ} \mathrm{F}=\left(1.8 x^{\circ} \mathrm{C}\right)+32 \text {. }
$$

\section{Datums}

Vertical coordinate information is referenced to the National Geodetic Vertical Datum of 1929 (NGVD 29).

Elevation, as used in this report, refers to distance above vertical datum. 


\title{
Behavior and Dam Passage of Juvenile Chinook Salmon and Juvenile Steelhead at Detroit Reservoir and Dam, Oregon, March 2012-February 2013
}

\author{
By John W. Beeman, Hal C. Hansel, Amy C. Hansen, Scott D. Evans, Philip V. Haner, Tyson W. Hatton,
} Eric E. Kofoot, Jamie M. Sprando, and Collin D. Smith

\begin{abstract}
The in-reservoir movements and dam passage of individual juvenile Chinook salmon (Oncorhynchus tshawytscha) and juvenile steelhead (Oncorhynchus mykiss) were studied at Detroit Reservoir and Dam, near Detroit, Oregon, during 2012 and 2013. The goal of the study was to provide data to inform decisions about future downstream passage alternatives and factors affecting downstream passage rates with the existing dam configuration. In 2012, 468 juvenile Chinook salmon and 200 juvenile steelhead were tagged and released during a 3-month period in the spring, and another 514 juvenile Chinook salmon were tagged and released during a 3-month period in the fall. The fish were surgically implanted with a small acoustic transmitter with an expected life of about 3 months and a passive integrated transponder tag with an indefinite life, and were released into the two main tributaries several kilometers upstream of the reservoir. Juvenile Chinook salmon migrated from the release sites to the reservoir in a greater proportion than juvenile steelhead, but once in the reservoir, juvenile steelhead migrated to the forebay faster and had a higher dam passage rate than juvenile Chinook salmon. The routes available for passing water and fish varied throughout the year, with low reservoir elevations in winter and high reservoir elevations in summer in accordance with the flood-control purpose of the dam. Most dam passage was through the spillway during the spring and summer, when the reservoir elevation was high and the spillway and powerhouse were the most common routes in operation, and via the powerhouse during the fall and winter period, when the reservoir elevation was low and the regulating outlet and powerhouse were the most common routes in operation. Few tagged fish passed when the powerhouse was the only route in operation. Dam passage rates during the spring and summer were greatest at night, increased with dam discharge, and were greater when water was passed freely over the spillway compared to when it was controlled by the spillway Tainter gates. Dam passage rates during the fall and winter, when the reservoir elevation usually was too low for spillway operation, were lower than during the spring and summer, negatively related to reservoir elevation, and positively related to dam discharge, though the latter relation diminished as reservoir elevation decreased. Fish locations near the dam from estimates of three-dimensional positions often were near the locations of dam discharge and fish depths were surface oriented relative to the depth of the forebay. Fish passage rates with the existing dam configuration were greatest when the spillway was in operation and were lowest when the powerhouse was the only route in operation; the latter result may be related to the relatively low magnitude or variability in discharge during that condition. The available data suggest that a properly designed surface outlet could be a viable passage route for juvenile Chinook salmon and juvenile steelhead at Detroit Dam. A second year of data collection based on a similar study design was complete at the time of this report.
\end{abstract}




\section{Introduction}

The U.S. Army Corps of Engineers (USACE) operates the Willamette Project (Project) in western Oregon, including a series of dams, revetments, and hatcheries. The primary purpose of the Project is flood control, but it also is operated to provide hydroelectricity, irrigation water, navigation, instream flows for wildlife, and recreation. The Project includes 13 dams, about $68 \mathrm{~km}$ of revetments, and several fish hatcheries. Detroit Dam and several other dams are located on tributaries of the Willamette River (fig. 1). The National Oceanic and Atmospheric Administration (2008) determined that the Project was jeopardizing the sustainability of anadromous fish stocks in the Willamette River Basin.

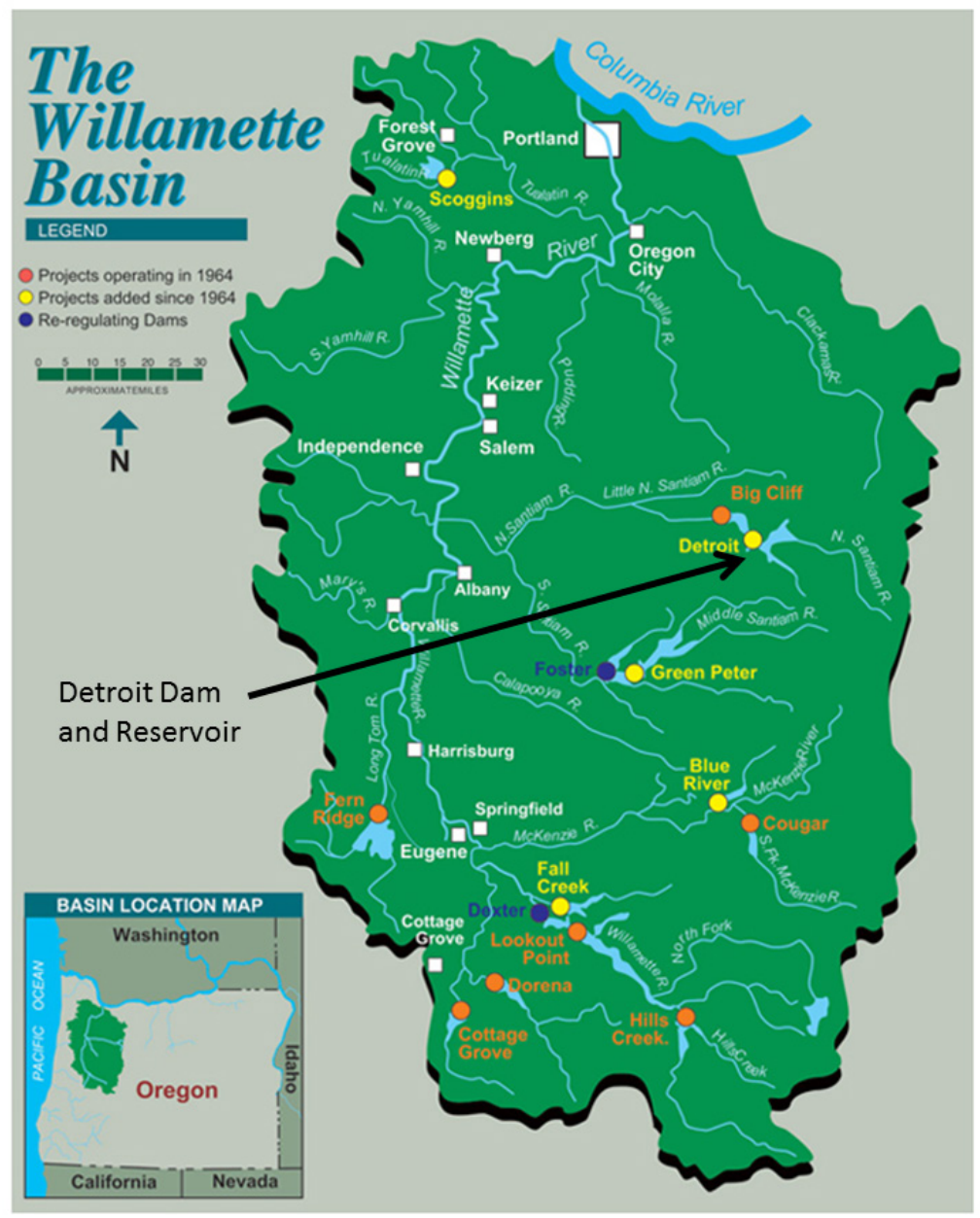

Figure 1. The Willamette River Basin showing dams and reservoirs of the Willamette Project, Oregon. Graphic from U.S. Army Corps of Engineers. 
In 1953, the USACE constructed the Detroit Dam and Reservoir on the North Santiam River near Salem, Oregon. The primary purposes of the dam are flood control, power generation, navigation, and recreation. The dam has six spill bays, five regulating outlets and two Francis turbines with a total hydraulic capacity of $5,340 \mathrm{ft}^{3} / \mathrm{s}$ and a generating capacity of 115 megawatts (fig. 2). The tops of the turbine intakes are at an elevation of 1,418.8 $\mathrm{ft}$ and the tops of the upper regulating outlet openings are at an elevation of $1,356.2 \mathrm{ft} ; 62.6 \mathrm{ft}$ lower than the turbine intakes. The spillway ogee is at elevation $1,541.0 \mathrm{ft}$. Reservoir elevation normally ranges from 1,450 to $1,563.5 \mathrm{ft}$ with highest elevations in the summer and lowest elevations in the winter for flood control purposes. Fluctuations in discharge at Detroit Dam to meet power demand are re-regulated at Big Cliff Dam $4.2 \mathrm{~km}$ downstream.

Detroit Dam is operated in coordination with other dams in the Project. Flood control dams within the Project are filled during summer to benefit recreation and power generation and drawn down during the fall and winter to facilitate their flood-control purpose. Detroit Dam is scheduled as the first dam in the Project to fill during the spring and the last dam to be drawn down during the fall; refill normally begins on February 1. Site-specific rules also govern the use of the spillway and regulate outlets, depending on forebay elevation, such that the two routes rarely are used together.

The 2008 Willamette Biological Opinion requires improvements to operations and structures to reduce impacts on Upper Willamette River (UWR) Chinook salmon (Oncorhynchus tshawytscha) and UWR steelhead (Oncorhynchus mykiss) (National Oceanic and Atmospheric Administration, 2008). The improvements include a requirement to mediate unseasonable water temperatures passed through the high-head dam by 2017 and to install fish passage facilities (or operational alternatives) at Detroit Dam by 2023 . Among the alternatives designed to meet these mandates is a temperature control structure at the dam that also enables downstream fish passage. However, in the interim period, downstream

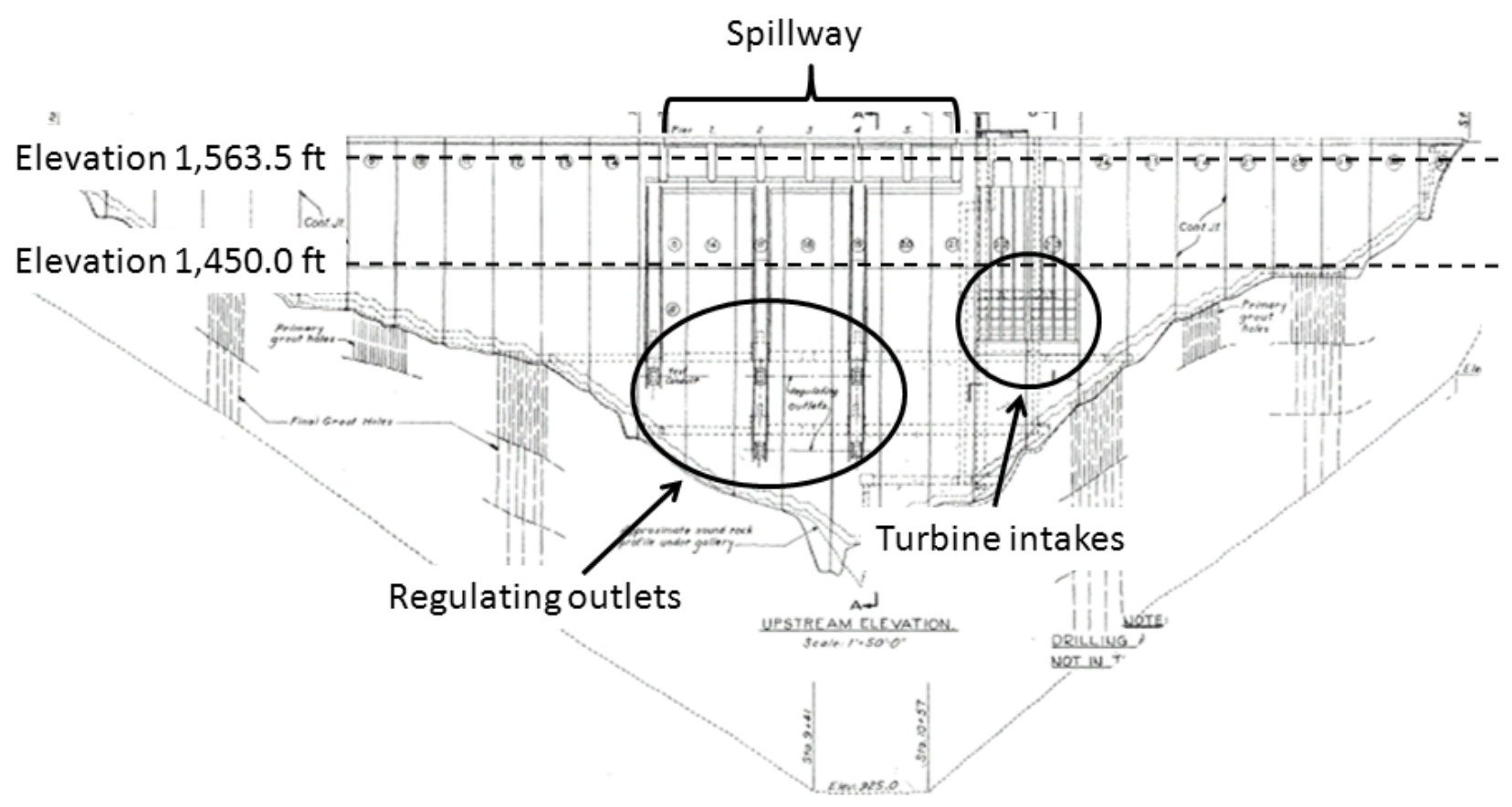

Figure 2. Elevation view of the upstream side of Detroit Dam showing outlet structures and elevations of full and minimum conservation pool. Modified from U.S. Army Corps of Engineers. 
passage of juvenile anadromous salmonids is to be achieved with the current configuration of the dam. Thus, there is a need for data about the distribution and migration behaviors of juvenile anadromous salmonids to aid in the design of future passage facilities, as well as for data about factors that affect their dam passage rates during the existing configuration.

The study summarized in this report was designed to quantify behavior of juvenile Chinook salmon and juvenile steelhead in the reservoir and near the dam to help understand their spatial and temporal movements and to quantify operational and biological factors affecting their dam passage rates with the current dam configuration. Fish implanted with acoustic transmitters with an expected life of about 3 months were the basis of inference. The study was designed to collect data from fish released in the spring (March, April, and May) and fall (September, October, and November) 2012. This study is similar to one conducted in Cougar Reservoir, another high-head dam in the Willamette River Basin (Beeman and others, 2013), and is part of a suite of research studies designed to collect information relative to the 2008 Willamette Biological Opinion mandates.

\section{Methods}

\section{Dam Operations and Environmental Conditions}

Powerhouse discharge, regulating outlet discharge, spillway discharge, forebay elevation, and water temperature data were summarized for the 2012 study period to document the environmental conditions that juvenile salmonids experienced during the detection periods. Hourly powerhouse discharge, regulating outlet discharge, spillway discharge, spill gate openings, and forebay elevation data were obtained from the USACE. Data were summarized using the hourly observations, but mean daily values were plotted to increase clarity in the plots. Water elevation data and fish depths are presented in feet and discharge is presented as cubic feet per second in accordance with the local convention. Hourly temperature data were obtained from the USACE Web site, $h t t p: / / w w w . n w d-$ wc.usace.army.mil/tmt/documents/ops/temp/string_by_project.html. Diel periods were assigned using U.S. Naval civil twilight. Civil twilight for Detroit, Oregon, was obtained at http://www.usno.navy.mil/USNO/astronomical-applications.

\section{Fish Capture, Handling, Tagging, and Release}

All test fish were of hatchery origin. The fish were yearling (used in the spring) and subyearling (used in the fall) juvenile hatchery Chinook salmon and yearling juvenile summer hatchery steelhead, hereafter referred to as Chinook salmon and steelhead, respectively. The Chinook salmon were reared at the Fish Performance and Genetics Laboratory (FPGL) in Corvallis, Oregon. The steelhead were transported from the Willamette Hatchery in Oakridge, Oregon, in mid-February and held at the Marion Forks Hatchery for the spring study period only. A total of 323 steelhead were sorted by size at the Willamette Fish Hatchery and transported to the Marion Forks Hatchery in an insulated 1,556-L plastic tank. They were then held in an indoor circular 1,065-L tank supplied with flowing river water until they were tagged.

All fish were delivered and held at Marion Forks Hatchery prior to tagging. Chinook salmon were held 8-29 d prior to tagging, depending on when they were tagged during the month. Chinook salmon were delivered on a regular basis by FPGL employees. For the first month of the study, approximately 100 Chinook salmon were delivered every other week. Thereafter, approximately 190 Chinook salmon were delivered once during each tagging month. A total of 651 Chinook salmon between March and May 2012 and 679 Chinook salmon between September and November 2012 were 
transported to Marion Forks Hatchery. Chinook salmon were sorted prior to transportation to the Marion Forks Hatchery to meet a fork length requirement of 95-180 $\mathrm{mm}$. Because of the warmer rearing temperatures at the FPGL than at the Marion Forks Hatchery, fish were tempered by FPGL personnel during transport. Blocks of ice made from well water were placed into the transport tank if the temperature difference between the two water sources was greater than $6{ }^{\circ} \mathrm{C}$. Personnel stopped periodically to monitor water temperature and dissolved oxygen throughout the $3 \mathrm{~h}$ of transport time. Once the fish were at the hatchery, temperature was checked in both the transport tank and the hatchery water to confirm both water temperatures were within $2^{\circ} \mathrm{C}$. If they were, fish were transferred to their holding location. When the temperature difference was greater than $2{ }^{\circ} \mathrm{C}$, the fish were tempered further using water from the hatchery. Once the temperatures were within $2{ }^{\circ} \mathrm{C}$ of each other, fish were then transferred to the holding location. In the spring, the Chinook salmon were held in an indoor circular 1,065-L tank supplied with continuously flowing river water. In the fall, Chinook salmon were held in a large outdoor circular holding pond also supplied with continuously flowing river water. The outdoor pond for the Chinook salmon and the post-tag recovery pond for both species were $7.3 \mathrm{~m}$ across and $0.65 \mathrm{~m}$ deep, and held 27,750 L of river water. On 1 or $2 \mathrm{~d}$ of every other week in spring (March-May) and fall (September-November) fish were netted from either the indoor tank or outdoor pond, depending on the time of year, and placed into two 264-L holding tanks; the fish were unfed for 18-30 h prior to tagging. The recommendations from the Surgical Protocols Steering Committee (2011) were followed in all aspects of fish holding, tagging, and releasing except in one instance described in the section, "Fish Capture, Handling, Tagging, and Release."

Transmitter implantation and fish recovery also were completed at Marion Forks Hatchery. Fish were considered suitable for tagging if they were free of major injuries; had no external signs of gas bubble trauma, major fin damage, or fungus; were less than or equal to 20 percent descaled; had no visible signs of disease or deformities; and were not previously tagged other than with a coded-wire-tag (Surgical Protocols Steering Committee, 2011). To implant the transmitter, fish were anesthetized using buffered tricane methanesulfonate (MS-222, Argent Chemical Laboratories, Redmond, Washington). The MS-222 concentration varied because it affected each species differently at different water temperatures. The concentration range for Chinook salmon was $82-146 \mathrm{mg} / \mathrm{L}$, whereas the concentration range for steelhead was $80-96 \mathrm{mg} / \mathrm{L}$ depending on the water temperature. Fish weight and length were measured immediately prior to the surgery. The acoustic transmitters (model SS300, Advanced Telemetry Systems; Isanti, Minnesota) were $10.72 \mathrm{~mm}$ long $\times 5.22 \mathrm{~mm}$ wide $\times 3.16 \mathrm{~mm}$ deep; with a mass of $0.31 \mathrm{~g}$ in air. Expected transmitter life at the nominal pulse repetition interval of 16 s was 90 d. A 12.5-mm-long passive integrated transponder (PIT) tag (model SST, Biomark, Boise, Idaho) weighing $0.10 \mathrm{~g}$ was placed inside the body cavity along with the acoustic transmitter. All weighing, measuring, and containment equipment were treated with a $0.25 \mathrm{~mL} / \mathrm{L}$ concentration of Stress Coat $^{\circledR}$ (Aquarium Pharmaceuticals, Inc., Chalfont, Pennsylvania) to reduce handling-related stress to the fish via electrolyte loss. Fish were placed in a $19 \mathrm{~L}$ perforated recovery bucket filled with $7 \mathrm{~L}$ of river water immediately after surgery. Dissolved oxygen concentrations were maintained between 80 and 110 percent of saturation during recovery. The mean density in a recovery bucket was $12.4 \mathrm{~g} / \mathrm{L}$ for Chinook salmon and $17.4 \mathrm{~g} / \mathrm{L}$ for steelhead, but we did not exceed three fish in a recovery bucket for either species. Throughout the entire tagging and releasing process, water quality (temperature, dissolved oxygen, total dissolved gas) was monitored in all holding buckets, transport tanks, the recovery pond, and release sites. Fish in the recovery buckets were observed periodically during the first 10 min after surgery to ensure that they recovered from anesthesia. Recovery buckets, fitted with bicycle inner tubes near their tops for flotation, were then fitted with lids and floated in an outdoor concrete pond with flowing river water where fish were held prior to release with access to air to adjust their buoyancy. 
Tagged fish were released after an 18-36 h recovery period into either the North Santiam River or the Breitenbush River. All recovery buckets were removed from the recovery pond, inspected for mortalities, and transferred into an insulated 1,556-L plastic tank filled with river water. The fish were driven either $22.5 \mathrm{~km}$ to the North Santiam River release site or $29.9 \mathrm{~km}$ to the Breitenbush River release site from the Marion Forks Hatchery; one trip per site. The North Santiam River release site was approximately $3.99 \mathrm{rkm}$ and the Breitenbush River release site was approximately $2.78 \mathrm{rkm}$ upstream of Detroit Reservoir. Fish were released near the center of the river at the North Santiam River site by lowering buckets from the bridge using a rope-pulley system. Fish released at the Breitenbush River site were carried down to the edge of the river and released from the shoreline. Water-quality measurements were recorded to ensure that the water temperature difference between the recovery buckets and the river was not greater than $2^{\circ} \mathrm{C}$, which would have required tempering; tempering was rarely required. All fish were released by partially submerging the buckets in the river and inverting them.

\section{Acoustic Telemetry Detection Systems}

Signals from acoustic transmitters were detected using autonomous and cabled types of Juvenile Salmon Acoustic Telemetry System (JSATS) hydrophone systems provided by the USACE. Acoustic signals from tagged fish in the reservoir from approximately the log boom at the boat-restricted zone upstream to near the head of the reservoir at Piety Island were detected using autonomous hydrophones spaced across the reservoir width at four locations (fig. 3). Additionally, we deployed a single autonomous hydrophone each in the Kinney Creek and Blowout Creek arms of Detroit Reservoir. A single autonomous hydrophone was installed at Big Cliff Dam, $2.75 \mathrm{rkm}$ downstream of Detroit Dam, to confirm fish passage at Detroit Dam. We empirically determined in the east arm of Cougar Reservoir, Oregon, in 2011 that 82 percent of the expected number of transmissions were detected at a range of $105 \mathrm{~m}$, and 10 percent were detected at a range of $180 \mathrm{~m}$. Based on that data, the hydrophones were spaced about $100 \mathrm{~m}$ from shorelines and $200 \mathrm{~m}$ from one another at a depth of about $33 \mathrm{~m}$ from the water surface along lines across the reservoir (hereafter referred to as "arrays"). Hydrophone depths were readjusted as necessary during bi-weekly visits to change batteries and download data. Hydrophones were deployed using methods similar to those described by Titzler and others (2010), except that burlap bags of sand were used as anchors. Sixteen autonomous hydrophones, including the one at Big Cliff Dam, were operational beginning on March 16, 2012. An additional autonomous hydrophone was added near the north shore at the array near Piety Island from May 7 to October 9, 2012, when reservoir water levels were sufficient to allow for installation. The autonomous hydrophones in the Kinney Creek and Blowout Creek arms were installed on May 22, 2012. On September 11, 2012, we installed a third autonomous hydrophone (between the original two hydrophones) at the array near the log boom at the boat-restricted zone. 
Acoustic signals from tagged fish near the dam were detected using five 4-hydrophone cabled systems linked to each other using a common clock. Each of these systems included four hydrophones connected with cables to a common computer. Each computer received its system time from a global positioning system (GPS). The use of a common time for all hydrophones allows estimation of fish position based on time of signal arrival if hydrophone locations and the speed of sound in the study area are known. A GPS was used to determine locations of hydrophones deployed from floating platforms. Javad (San Jose, California) Global Navigation Satellite System (GNSS) Sigma receivers were used to collect positional data on moving hydrophones deployed in the forebay. The receivers were programmed to provide real-time kinematic positions every $5 \mathrm{~s}$. Dorne-Margolin choke ring antennas with Southern California Integrated GPS Network radomes were used to minimize multipath signals from surrounding concrete and rock structures to increase the quality of position solutions. This combination of equipment used GPS, GLONASS (Russian satellites), and Galileo satellites to compute positions within $\pm 1 \mathrm{~cm}$. The cabled hydrophone system is described by Weiland and others (2009).

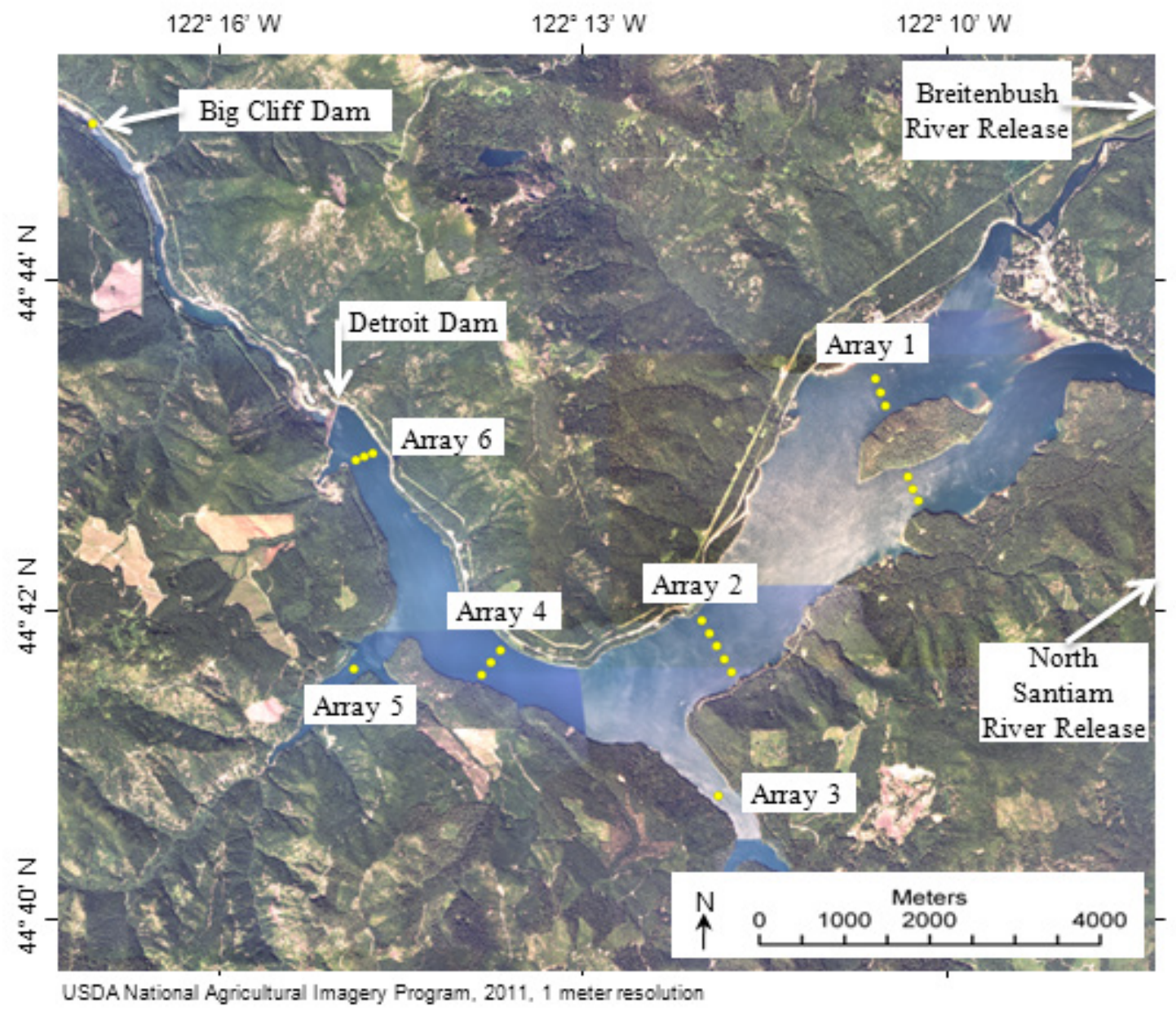

Figure 3. Locations of autonomous acoustic receivers (yellow circles) deployed in Detroit Reservoir, Oregon, 2012. 
The cabled hydrophone systems were installed along the face of Detroit Dam at several elevations and from floating platforms (figs. 4, 5, and 6). All cabled hydrophones were installed prior to the first release of acoustic-tagged fish, except for the three floating hydrophones at the spillway pier noses, which were installed on June 26, 2012. The four hydrophones affixed to the dam face just below the spill bay crest were operational only when the forebay elevation was above 1,531.0 ft. The range of the cabled hydrophone systems was assumed to be similar to that of the autonomous hydrophones. This assumption seemed reasonable, because each transmitter message was typically detected by nearly all hydrophones, which were spaced a maximum of $61 \mathrm{~m}$ apart.

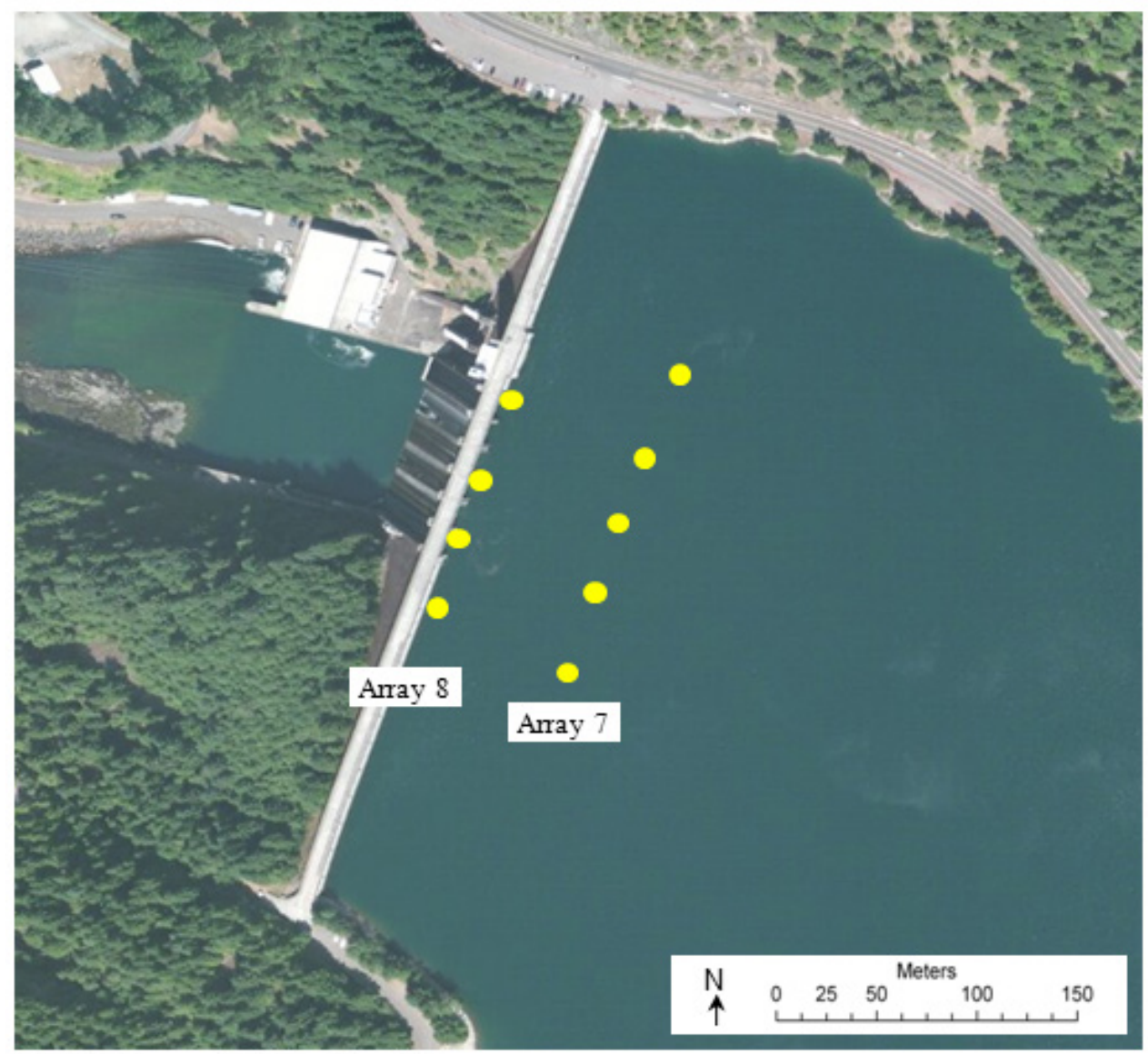

ESRI World Imagery, 2011, 0.5 meter resolution

Figure 4. Locations of cabled hydrophones (yellow circles) on floating platforms deployed in Detroit Reservoir, Oregon, 2012. 


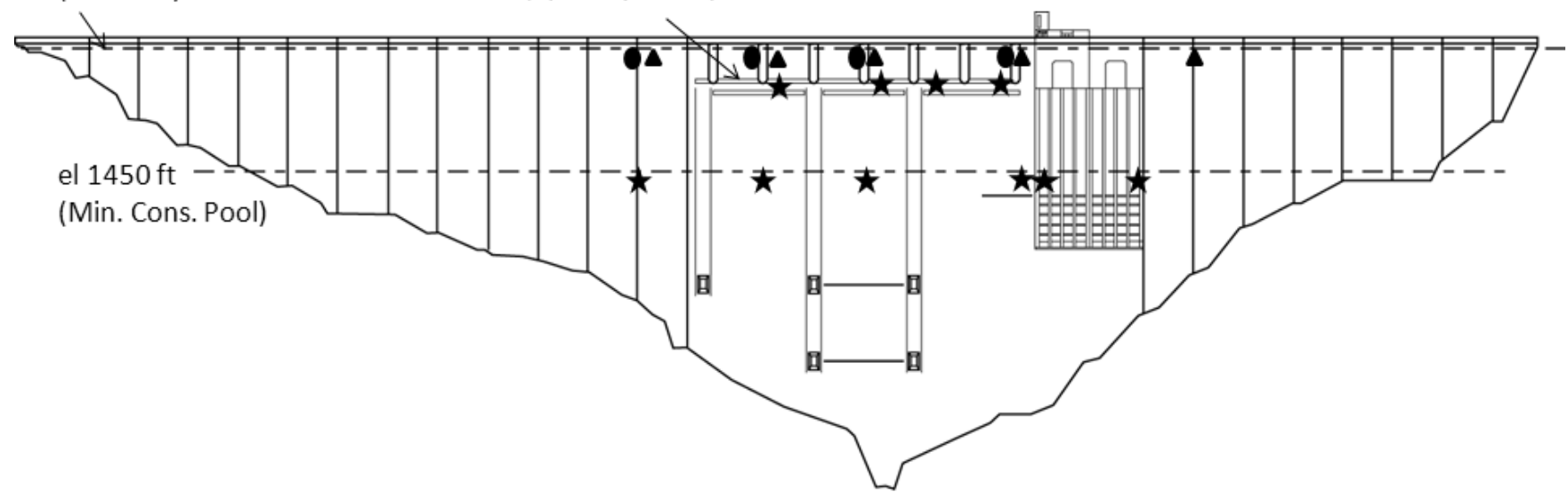

Figure 5. Schematic showing locations of cabled hydrophones at Detroit Dam, Oregon, 2012. Stars represent hydrophones affixed to the dam face, ovals indicate hydrophones deployed from floating platform attached to guide cables on the dam face, and triangles represent hydrophones deployed from floating platforms anchored 61 meters upstream of the dam face. Dotted lines represent approximate locations of full and minimum conservation pool elevations of 1,569 and 1,450 feet, respectively.

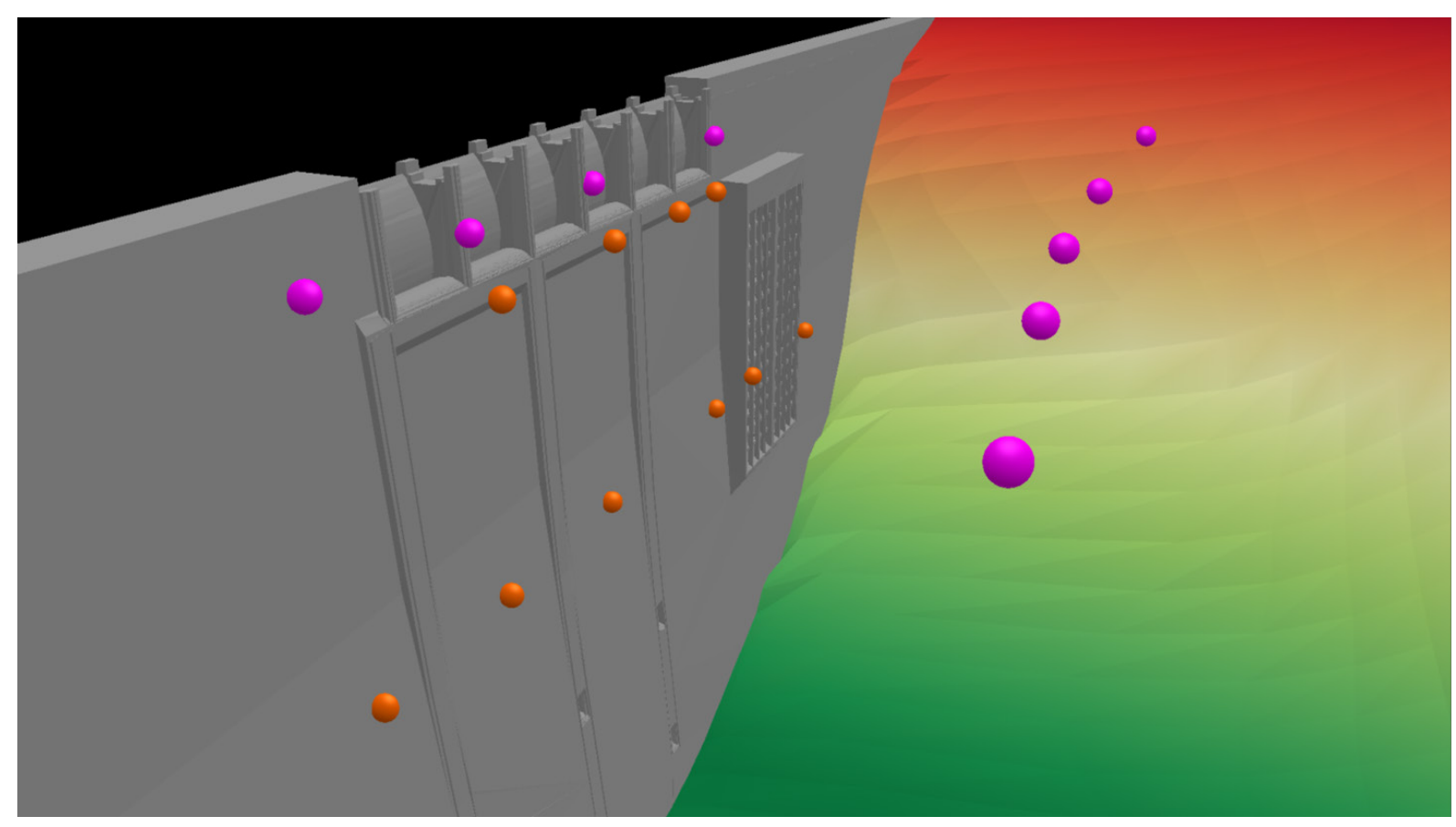

Figure 6. Schematic showing locations of underwater cabled hydrophones at Detroit Dam, Oregon, 2012. Gray surface is a three-dimensional representation of the dam face. Reservoir bed elevations are illustrated by the ramped colors, with greens showing low elevations and reds showing high elevations. Pink spheres are floating hydrophones that move with the forebay elevation and orange spheres are non-floating hydrophones attached to the dam face. 


\section{Data Management and Analysis}

\section{Transmitter Life Tests}

We selected 50 transmitters from the spring tags and 50 transmitters from the fall tags and empirically determined tag life. We used the same transmitter model in studies at Cougar and Detroit Reservoirs, so a single tag-life study was conducted using 25 tags from the tag allocation of each study. We activated the spring tags on March 26, 2012, and the fall tags on August 24, 2012, and placed them in a $3.25 \times 11.0 \times 1.25 \mathrm{in} .(82.6 \times 279.4 \times 31.7 \mathrm{~mm})$ plastic box submerged in a $5 \mathrm{ft}(1.5 \mathrm{~m})$ diameter circular tank at the U.S. Geological Survey's (USGS) Columbia River Research Laboratory in Cook, Washington. The water temperature in the tank was controlled to reflect average monthly temperatures in the upper $20 \mathrm{ft}$ of the Cougar Dam and Detroit Dam forebays. The tag signals were monitored with an Advanced Telemetry Systems model Trident SR5000 receiver. Data were run through the same filter as the fish detection data and summarized with the time-to-event Kaplan-Meier survivorship analysis.

\section{Removing False-Positive Records}

Data from the hydrophones were processed to remove false-positive records prior to analysis of presence data. False-positive records are those that indicate detection of a transmitter when the transmitter was not present, and are common in most active telemetry systems. We used the procedures developed by Pacific Northwest National Laboratory (Mark Weiland, Pacific Northwest National Laboratory, written commun., June 17, 2010) to remove false-positive records. The steps include removing records from tag codes not released, records suspected of being from reflections of valid tag signals (multipath), and records that are not close to a multiple of the tag pulse interval (McMichael and others, 2010). Records from the cabled hydrophone system also were required to be present on more than one hydrophone to be retained.

\section{Estimating Fish Positions}

Fish positions within the area monitored by the cable hydrophone system near the dam were estimated using software under development through a USGS subcontract with the University of Washington. The software estimates fish positions with an iterative technique using the Gauss-Newton method to find the location that minimizes the root-mean squared misfit to all available arrival time data by repeatedly solving a set of linearized equations relating adjustments in location to changes in the arrival time misfit (Klein, 1978; Lee and Stewart, 1981; Menke, 1989; Speisberger and Fristrup, 1990). The software uses all available hydrophones and can adjust the speed of sound in water for vertical changes in water temperature using the method of Moser (1991). Water temperatures from the temperature string located near the Detroit Dam forebay log boom were used for this purpose. Further efforts to create a graphical user interface and user documentation for the software were underway at the time of this report.

Fish position estimates were passed through a filter to identify spurious results. The filter limited swim speeds to a burst speed of as much as $3 \mathrm{~m} / \mathrm{s}$ for $20 \mathrm{~s}$ or a sustained speed of as much as $1.0 \mathrm{~m} / \mathrm{s}$ for longer than $20 \mathrm{~s}$ based on values from the literature (Bainbridge, 1960; Webb, 1978; Taylor and McPhail, 1985; Mesa and others, 2008). The first observation of each trip into the monitored area was omitted because of the lack of data to estimate swim speed, where a new trip was assigned if the time elapsed between successive positions was greater than the 99th percentile of successive detections $(2,879 \mathrm{~s})$. The filter identified 2.2 percent of the estimated positions, which were removed prior to analysis. 
Fish position estimates were used to describe the densities, depths, and paths of fish near the dam. Fish densities were estimated by dividing the monitored area near the dam into cells and interpolating over the entire area using the kriging process. Percent presence in the horizontal plane (x, $y)$ was calculated as the percentage of fish present at least once in each $10-\mathrm{m} \times 10-\mathrm{m}$ cell in the $\mathrm{x}-\mathrm{y}$ plane. Percent presence in the vertical plane $(\mathrm{x}, \mathrm{z})$ was calculated as the percentage of fish present at least once in each $20-\mathrm{m} \times 10-\mathrm{m}$ cell in the $\mathrm{x}-\mathrm{z}$ plane. The mean hourly depths of each species were calculated from the median hourly depths of each fish. The position estimates from a randomly selected group of fish were used as examples of fish locations near the dam.

\section{Movements within the Reservoir and Dam Passage}

Descriptions of fish behavior and an analysis of factors affecting rates of movement in the reservoir and rate of dam passage were based on detections of the tagged fish. General fish movements between arrays over time were plotted as an example of the raw data used in subsequent analyses. Analyses of fish presence (probability of presence at each array and across all arrays between release and the dam) and movement probabilities (Markov transition probabilities) were based on detections of fish at the arrays. Data from fish with position estimates within $25 \mathrm{~m}$ of the dam were used to assess selected factors that affected dam passage rates.

Dam passage was determined using presence data from the cabled hydrophones nearest Detroit Dam. The date and time of assigned dam passage events were assigned if the first detection of the last transmitted message was at any of the hydrophones located on Detroit Dam that were closest to the water outlets. This method was selected to limit passage assignments to fish last detected in the area generally in front of the spillway, powerhouse, or regulating outlet when operating, and was consistent with histories of tagged fish known to have passed the dam based on detections of acoustic tags or PIT tags downstream. Several general measures of fish passage were estimated from these data (table 1).

Table 1. Definitions of passage efficiency and effectiveness metrics.

[RO, regulating outlet; Number, number of tagged fish; na, not applicable]

\begin{tabular}{|c|c|c|}
\hline Metric & Acronym & Definition \\
\hline $\begin{array}{l}\text { Stream passage } \\
\text { efficiency }\end{array}$ & STRE & Number detected in the reservoir divided by number released. \\
\hline $\begin{array}{l}\text { Reservoir passage } \\
\text { efficiency }\end{array}$ & RPE & Number detected at array 6 divided by number detected in the reservoir. \\
\hline Dam passage efficiency & DPE & Number passing the dam divided by number detected at array 6 . \\
\hline Spill passage efficiency & SPE & $\begin{array}{l}\text { Number passing the spillway divided by number passing the dam with known } \\
\text { routes. }\end{array}$ \\
\hline RO passage efficiency & $\mathrm{ROE}$ & Number passing the RO divided by number passing the dam with known routes. \\
\hline Fish passage efficiency & FPE & Percent passing through non-turbine routes (ROE plus SPE). \\
\hline $\begin{array}{l}\text { Turbine passage } \\
\text { efficiency }\end{array}$ & TURE & $\begin{array}{l}\text { Number passing the turbines divided by number passing the dam with known } \\
\text { routes. }\end{array}$ \\
\hline RO effectiveness & na & $\begin{array}{l}\text { ROE divided by percentage of dam discharge passing through the regulating } \\
\text { outlets. }\end{array}$ \\
\hline Spill effectiveness & na & SPE divided by percentage of dam discharge passing through the spillway. \\
\hline Turbine effectiveness & na & TURE divided by percentage of dam discharge passing through the turbines. \\
\hline
\end{tabular}


Analyses of the timing and rates of downstream movement in the reservoir and dam passage were conducted using time-to-event methods (Hosmer and Lemeshow, 1999). These methods are ideally suited to analysis of data based on the timing of events, such as travel times, and the rates of event occurrences, such as the guidance, attraction, and passage of fish (Castro-Santos and Haro, 2003, 2010; Castro-Santos and Perry, 2012).

The time elapsed from fish release to three event types was described using Kaplan-Meier survivorship functions. The events are (1) detection by any hydrophone in Detroit Reservoir after release in the tributaries, (2) detection by the autonomous nodes at the log boom, and (3) dam passage. The survivorship function of a variable $T$ is defined as

$$
\mathrm{S}(t)=\operatorname{Pr}\{T>\mathrm{t}\}
$$

where

$T$ is a random variable with a probability distribution, denoting an event time for an individual.

If the event of interest is passing a dam, the survivorship function gives the probability of not passing the dam after time $t$. As such, the median time occurs when the survivorship function equals 0.5. In the absence of censoring, the survivorship function represents the proportion of the population that has not experienced an event (for example, passing the dam). Examining the survivorship function can be useful to describe the timing of events as well as the proportion of the population still at risk of the event at different points in time. Fish that had not experienced an event by the longest known transmitter life were right censored at that time.

Cox proportional-hazards regression was used to determine the potential effects of selected variables on the rates of dam passage. In Cox proportional-hazards regression, the rates of events are expressed as a hazard function defined as

$$
\mathrm{h}(\mathrm{t})=\lim _{\Delta t \rightarrow 0} \operatorname{Pr}\{\mathrm{t} \leq T<\mathrm{t}+1 \mid T \geq \mathrm{t}\} / \Delta \mathrm{t}
$$

representing the instantaneous risk, or rate, of an event occurring at time t. Equation 2 describes a conditional rate: It is the probability of the event occurring in a limited time interval, conditional on the event having not occurred yet, divided by the length of the interval (which makes it a rate, not a probability) (Allison, 1995). Results are expressed in terms of a hazard ratio that describes the change in the rate of interest for each unit increase in an independent variable. For continuous variables, the hazard rate is interpreted by subtracting 1 from the hazard ratio and multiplying the remainder by 100 percent. For dichotomous variables, the hazard ratio is interpreted directly. For example, a hazard ratio of 1.15 from a continuous covariate indicates that the rate of the event increases 15 percent for each unit increase in the covariate, and a hazard rate of 0.75 indicates a decrease of 25 percent per unit increase in the covariate. A hazard ratio of 2.00 for a dichotomous covariate (for example, day $=1$, night $=2$ ) indicates that the rate of the event is twice the value at the higher value relative to the lower value (at night compared to during the day in this example). Hazards are independent of the size of the population. The measure of interest generally is the hazard ratio, which is the ratio of the rate of an event relative to the values of a covariate (for example, night versus day). Hazard ratios of variables that are not involved in an interaction with one or more other variables can be read directly from most statistical package outputs. However, hazard ratios of variables involved in interactions must be estimated from the parameter estimates (slopes) of each variable involved in the interaction plus their interaction term or terms, and therefore, are not included in report tables. 
The counting-process-style data input was used to divide the data into diel period (day or night) and to increment other time-varying covariates by hour (Hosmer and Lemeshow, 1999). We reset the time interval each time an individual entered a new zone or when it passed the dam. Censor values used to delineate between no event, downstream movement, upstream movement, route-specific dam passage, or passage through an undetermined route were used in a competing risks analysis focusing on overall or route-specific dam passage. We used the 90th percentile of expected tag life based on the transmitter extinction tests to right censor the data (see section, "Transmitter Life Tests"). Cox regression is appropriate only for categorical variables that are proportional in the hazard and for numerical variables that are linear in the hazard, so these assumptions were evaluated prior to forming regression models. Models of factors supported as determinants of dam passage rates were formed by sequentially reducing full models by one variable at a time until only statistically significant variables remained at the $\alpha=0.10$ level. Independent variables including total project discharge, route-specific discharge, forebay elevation, diel period, fork length, species, and selected two-way interactions were considered in the full models if the factors met selection criteria. The selection criteria included bivariate correlations of less than 0.8 and meeting assumptions of linearity and proportionality in the hazards (Hosmer and Lemeshow, 1999). In some cases, the Akaike Information Criterion (AIC) was used to assess support for competing models. Analyses were conducted for dam operating conditions (the various combinations of powerhouse, spillway, and regulating outlets being on or off) with a sufficient number of passage events. Inasmuch as most fish made many trips into and out of the monitored area near the dam, we stratified the analysis into unique baseline hazard functions representing the 10th, 25th, 50th, 75th, and greater than the 75th percentiles of the number of trips into the monitored area.

\section{Movement Probabilities within the Reservoir}

The probabilities of upstream and downstream movements for fish detected at each array were estimated to determine if there were net upstream or downstream movements of fish and if the movements in the reservoir depended on past movements. Movement probabilities can be used to stochastically predict or simulate future fish movements (Johnson and others, 2004). A Markov-chain analysis was used to determine if movements between reservoir arrays followed a one-step process, by which movement from one array to an adjacent array is not dependent on its previous movement (a firstorder Markov process; Bhat and Miller, 2002). We estimated the probability of a fish moving from one array to the next as either a first-order, or one-step process, or two-step process (dependent on previous location), and assessed support of the hypotheses by the data using the AIC (Burnham and Anderson, 2002). 


\section{Probability of Presence near Detroit Dam.}

We estimated the probability that a fish was present at least once after release at each array or at the Detroit Dam forebay. The purpose of this analysis was to determine if fish near the head of the reservoir would be available for capture by a juvenile fish collection facility if one were present. This analysis does not indicate whether fish that were not detected at an array or near the dam were alive or dead, only that they were never detected in the area of interest while a fish tag was still active. The data were based on presence or absence of fish detected at the arrays throughout the reservoir or at the cabled hydrophone systems near the dam, which together detect fish within about $200 \mathrm{~m}$ of the dam.

The probability of fish being present near Detroit Dam at least once was estimated using Cormack-Jolly-Seber mark-recapture methodology (Cormack, 1964; Jolly, 1965; Seber, 1965) using Program MARK (White and Burnham, 1999). This method primarily is used to estimate survival and recapture (detection) probabilities in mark-recapture studies, but in this case we used it to estimate fish presence and recapture probabilities. Detection of a tagged animal is the joint probability of presence and being detected when present, so these parameters must be estimated separately. We constructed models of presence and recapture probabilities based on various hypotheses about differences among arrays. In this analysis, the "recapture probability" at an array is the probability of being detected at that array at least once. Overdispersion in the data was estimated using the median $\hat{c}$ procedure in Program MARK. Models describing different hypotheses about processes driving presence or detection probabilities were evaluated using the AIC with an adjustment for effects of sample size (AICc). Burnham and Anderson (2002) suggest that when AICc values differ by less than 2 units, the support for one hypothesis over another is not meaningfully different based on the data and models considered. However, one must cautiously evaluate models in this case to determine if the support of one of the models is simply because it is similar in structure to the other model. In such cases, the difference in the number of parameters between the two models is 1 and the deviance or log-likelihood is essentially the same; the additional variable is sometimes called a "pretender" variable. They also suggest that AICc differences of 4-7 indicate considerably less support for the model with the greater AICc, and differences greater than 10 indicate essentially no support for the model with the greater AICc. The probability of being present within $200 \mathrm{~m}$ of the dam at least once was estimated as the product of arrayspecific presence probabilities, with the standard error (SE) estimated using the delta method (Seber, 1982). When more than one probability of presence model was supported, leading to model-selection uncertainty, the probability of presence was estimated from model-averaged coefficients for all models with an AICc not 10 greater than the model with the lowest AICc. 


\section{Results}

\section{Transmitter Life Tests}

The estimated lives of the tags implanted in fish during the spring and fall were similar. The median life of the spring tags tested was $96.5 \mathrm{~d}$, and the maximum life was $115.8 \mathrm{~d}$ (fig. 7). The first tag stopped working after $87.8 \mathrm{~d}$ and the remaining tags stopped working shortly thereafter. The 90th percentile of tag life was $92.5 \mathrm{~d}$. The median life of the fall tags tested was $95.8 \mathrm{~d}$ and the maximum life was $111.4 \mathrm{~d}$. The first tag expired at $70.2 \mathrm{~d}$ and the 90 th percentile of tag life was $87.0 \mathrm{~d}$. To reduce the probability of false positive detections in the data, we truncated or censored each fish detection history at the 90th percentile of the empirically determined tag life.
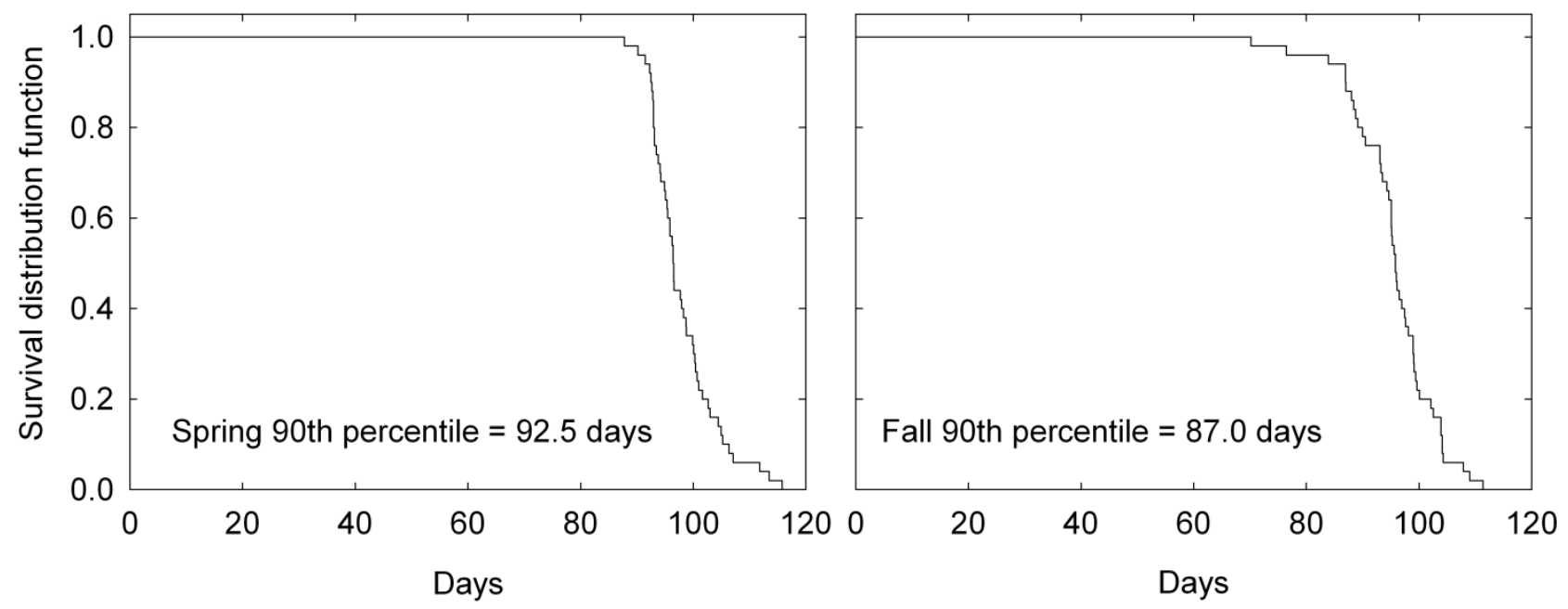

Figure 7. Graphs of transmitter extinction tests of the acoustic tag model used at Detroit Dam, Oregon, during the 2012 spring and fall study periods. 


\section{Definition of Spring and Fall Study Periods}

The study periods ranged from the first release until the estimated 90th percentile of tag life. Spring fish were released between March 13 and May 23, 2012. Our last spring detection date using the 90th percentile of tag life (92.5 d) from the last release was August 21, 2012. Fall fish were released between September 12 and November 28, 2012. Our last fall detection date using the 90th percentile of tag life $(87.0 \mathrm{~d})$ from the last release was February 21, 2013. Few tagged fish with active tags likely were in the reservoir between August 21 and September 12, 2012 (fig. 8).

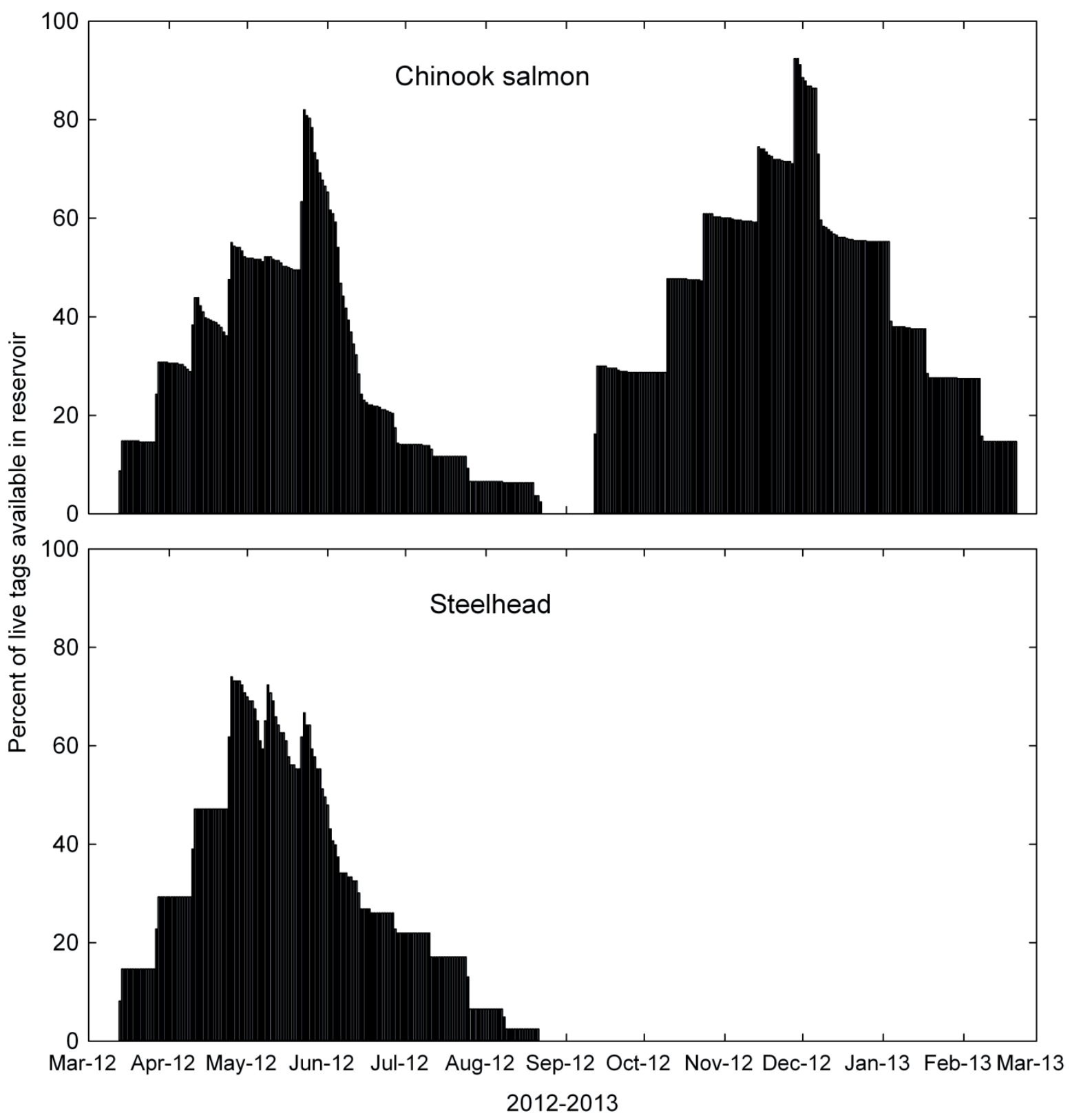

Figure 8. Graphs showing percentage of live tags available, by date, in Detroit Reservoir. Oregon, 2012-13. 


\section{Fish Capture, Handling, Tagging, and Release}

Chinook salmon and steelhead were tagged and released from March 13 to May 23, 2012, during the spring study period. Of the 468 tagged Chinook salmon, 236 were released into the North Santiam River (SAN) and 232 were released into the Breitenbush River (BRE). The tagged Chinook salmon released into the North Santiam River had a mean fork length of $142.6 \mathrm{~mm}$ (range 114-180 mm) and those released into the Breitenbush River had a mean fork length of $142.1 \mathrm{~mm}$ (range 116-179 mm) (table 2). The tagged steelhead $(N=200)$ were evenly divided between the North Santiam River and Breitenbush River release sites. The average fork lengths were $173.4 \mathrm{~mm}$ (range 156-180 mm) for tagged steelhead released into the North Santiam River and $172.7 \mathrm{~mm}$ (range 156-180 mm) for those released into the Breitenbush River (table 2). The fork lengths of the fish released at the two sites were similar within species (1-way analysis of variance, $\left.P_{\text {Chinook }}=0.65, P_{\text {steelhead }}=0.38\right)$. The tag-weight-tobody-weight ratio based on the $0.41-\mathrm{g}$ weight of the acoustic transmitter plus the PIT tag ranged from 0.6 to 3.7 percent with an average of 1.4 percent for Chinook salmon, and ranged from 0.7 to 1.3 percent with an average of 0.9 percent for steelhead. Pre-tag holding times for Chinook salmon ranged from 16.7 to $24.5 \mathrm{~h}$ for fish released at the North Santiam River release site and from 18.5 to $21.6 \mathrm{~h}$ for fish released at the Breitenbush River release site. Steelhead released into the North Santiam River had a pre-tag holding range of 18.2 to $24.2 \mathrm{~h}$ and an 18.5 to $23.7 \mathrm{~h}$ holding range for fish released into the Breitenbush River. Pre-tag holding times were within the $18-30 \mathrm{~h}$ specification of the Surgical Protocols Steering Committee (2011) in all but one instance, excluding data from the fish prepared for tagging on May 7, 2012. On May 7, 2012, the pre-tag mortality of Chinook salmon increased, so no tagging occurred and the fish remained in the pre-tag holding tank until the next tagging session 2 weeks later to avoid further handling. Post-tag holding times for Chinook salmon ranged from 21.3 to $29.7 \mathrm{~h}$ for fish released at the North Santiam River release site and from 21.8 to $28.7 \mathrm{~h}$ for fish released at the Breitenbush River release site. Steelhead released into the North Santiam River had a post-tag holding time range of 20.5 to $28.7 \mathrm{~h}$ and steelhead released into the Breitenbush River had a post-tag holding time range of 19.3 to $28.3 \mathrm{~h}$. Post-tag holding times were within the 18-36 h specification of the Surgical Protocols Steering Committee (2011).

Table 2. Summary statistics of fork length and weight of acoustic- and PIT-tagged hatchery juvenile Chinook salmon and steelhead at Detroit Reservoir, Oregon, 2012.

[N, number of fish; SD, standard deviation. Release sites were SAN, North Santiam River, and BRE, Breitenbush River]

\begin{tabular}{|c|c|c|c|c|c|c|c|c|c|}
\hline \multirow{2}{*}{ Species } & \multirow{2}{*}{$\begin{array}{l}\text { Study } \\
\text { period }\end{array}$} & \multirow{2}{*}{$\begin{array}{c}\text { Release } \\
\text { site }\end{array}$} & \multirow[b]{2}{*}{$N$} & \multicolumn{3}{|c|}{$\begin{array}{l}\text { Fork length } \\
\text { (millimeters) }\end{array}$} & \multicolumn{3}{|c|}{$\begin{array}{c}\text { Weight } \\
\text { (grams) }\end{array}$} \\
\hline & & & & Mean & SD & Range & Mean & SD & Range \\
\hline \multirow{4}{*}{$\begin{array}{l}\text { Chinook } \\
\text { salmon } \\
\text { Steelhead }\end{array}$} & Spring & SAN & 236 & 142.6 & 12.5 & $114-180$ & 32.3 & 8.3 & $17.6-66.3$ \\
\hline & & BRE & 232 & 142.1 & 12.5 & 116-179 & 32.0 & 8.0 & $15.0-61.7$ \\
\hline & Spring & SAN & 100 & 173.4 & 5.8 & $156-180$ & 48.5 & 5.9 & $32.4-58.4$ \\
\hline & & BRE & 100 & 172.7 & 5.8 & $156-180$ & 47.6 & 5.2 & $35.8-58.6$ \\
\hline \multirow{2}{*}{$\begin{array}{l}\text { Chinook } \\
\text { salmon }\end{array}$} & Fall & SAN & 261 & 141.8 & 14.0 & $100-178$ & 30.6 & 9.9 & $13.1-63.1$ \\
\hline & & BRE & 253 & 141.6 & 12.8 & $101-173$ & 30.1 & 8.6 & $11.1-56.8$ \\
\hline
\end{tabular}


There were 30 pre-tag and no post-tag mortalities during the spring study period. There was 1 pre-tag mortality of the 391 Chinook salmon delivered prior to May ( 0.2 percent). There were 20 pre-tag mortalities of the 260 Chinook salmon delivered for the May tagging sessions (7.7 percent). Six of the pre-tag holding mortalities were implanted with active JSATS tags and released into the Detroit Dam tailrace as a test of false-positive detections at Big Cliff Dam; none were detected. Another six dead fish were sent to the U.S. Fish and Wildlife Service, Lower Columbia River Fish Health Center, in Willard, Washington, for examination. They found no evidence of trauma or disease, but did note that the fish had no parr marks, were very silvery, and had very heavy levels of a protozoan of the genus Hexamita in the gut. There were nine pre-tag mortalities of steelhead of the 316 being held for the study $(2.8$ percent) owing to fish jumping out of the source tank.

During the fall study period, Chinook salmon were tagged and released from September 12 to November 28, 2012. There were 261 tagged Chinook salmon released into the North Santiam River and 253 released into the Breitenbush River. The average fork lengths were $141.8 \mathrm{~mm}$ (range 100-178 mm) for those released into the North Santiam River and $141.6 \mathrm{~mm}$ (range 101-173 mm) for those released into the Breitenbush River (table 2). There were no steelhead tagged during the fall study period. The tag-weight-to-body-weight ratio based on the 0.41 -g weight of the acoustic transmitter plus the PIT tag ranged from 0.6 to 3.7 percent with an average of 1.5 percent. Pre-tag holding times ranged from 18.0 to $23.6 \mathrm{~h}$ for fish released into the North Santiam River and 18.8 to $23.8 \mathrm{~h}$ for fish released into Breitenbush River. Post-tag holding times ranged from 18.9 to $23.2 \mathrm{~h}$ for fish released into the North Santiam River and 18.7 to $25.6 \mathrm{~h}$ for fish released into the Breitenbush River. The pre-tag and post-tag holding times during the fall study period were within the specifications of the Surgical Protocols Steering Committee (2011).

In the spring, both release locations combined had a post-tagging mortality rate of 1.3 percent for Chinook salmon and 1.0 percent for steelhead. Post-tag mortality of Chinook salmon was 0.9 percent ( 2 of 235) of fish released at the North Santiam River site and 2.5 percent (6 of 239) for fish released at the Breitenbush River site. There were no post-tag mortalities of the steelhead released at the North Santiam River site and 2 of 102 (2.0 percent) of those released at the Breitenbush River site. During the fall study period, there were pre-tag mortalities, but no post-tag mortalities. There were 8 pre-tag mortalities in early September and 29 pre-tag mortalities in early October for a total of 6.0 percent (37 of 620).

\section{Environmental Conditions and Dam Operations}

Project operations at Detroit Dam varied during the spring study period. Hourly project discharge peaked in April and decreased throughout the remainder of the spring period. The mean hourly project discharge was $2,394.5 \mathrm{ft}^{3} / \mathrm{s}$ (range $0.0-12,141.7 \mathrm{ft}^{3} / \mathrm{s}$ ) and was similar during the day and night (table 3). During the spring study period, the project discharge was commonly passed through the powerhouse (primarily during the day) and the spillway, but the regulating outlets rarely were used (fig. 9). Spill, water passed through the spillway, began on April 2 and continued intermittently until September 23 when the forebay elevation decreased below the spillway ogee elevation of 1,541 ft (figs. 9 and 10). All spill bays were used, but 59.0 percent of the time only spill bays 4 and 5 were open. Mean hourly spill discharge was $1,265.0 \mathrm{ft}^{3} / \mathrm{s}$ (range $0.0-7,453.4 \mathrm{ft}^{3} / \mathrm{s}$ ) and the spill-only operation constituted 41.3 percent of the spring study period. Regulating outlet number 2 , the northernmost outlet at the upper elevation, operated for $5 \mathrm{~h}$ on April 6. Forebay elevation increased until early May and the reservoir remained full through the end of August (range 1,519.1-1,565.0 ft). The turbine(s) in the powerhouse operated during nearly one-half of the spring study period-24.7 percent as turbine(s) only and 22.7 percent as turbine(s) plus spill. During this period, one, both, or neither turbine was used and 
the mean powerhouse discharge when operating was $2,522.3 \mathrm{ft}^{3} / \mathrm{s}$. There was no discharge through the dam 11.2 percent of the time. The temperature of the top $20 \mathrm{ft}$ of the reservoir increased steadily until mid-summer and the mean hourly temperature of the top $20 \mathrm{ft}$ of the forebay water was $11^{\circ} \mathrm{C}$ (range $\left.3.7-21.8^{\circ} \mathrm{C}\right)$.

Water was passed over the spillway ogee without regulation by the Tainter gates (hereafter referred to as "weir spill") during part of April. Weir spill occurred from April 6 at 4:00 p.m. through April 20 at 3:00 a.m., except for 43 continuous hours on April 18 and 19. Forebay elevation ranged from $1,547.1$ to $1,543.7 \mathrm{ft}$ and powerhouse discharge ranged from 0 to $2,138.9 \mathrm{ft}^{3} / \mathrm{s}$. Mean weir spill discharge was $2,387.2 \mathrm{ft}^{3} / \mathrm{s}$ and ranged from $1,201.9$ to $7,453.4 \mathrm{ft}^{3} / \mathrm{s}$. The number of spill bays open during weir spill was predominantly two, but ranged from one to six.

Table 3. Mean hourly summary statistics of dam operations and environmental conditions at Detroit Reservoir, Oregon, from March 13-August 21, 2012, when spring-released fish were detected in the study area.

[SD, standard deviation; RO, regulating outlet; $\mathrm{ft}^{3} / \mathrm{s}$, cubic foot per second]

\begin{tabular}{|c|c|c|c|c|c|}
\hline & Period & Mean & Median & Range & SD \\
\hline \multirow[t]{3}{*}{ Total project $\left(\mathrm{ft}^{3} / \mathrm{s}\right)$} & Overall & $2,394.5$ & $2,011.1$ & $0.0-12,141.7$ & $1,499.1$ \\
\hline & Day & $2,568.9$ & $2,053.0$ & $0.0-12,141.7$ & $1,324.4$ \\
\hline & Night & $2,137.8$ & $1,914.7$ & $0.0-9,824.8$ & $1,692.4$ \\
\hline \multirow[t]{3}{*}{ Powerhouse $\left(\mathrm{ft}^{3} / \mathrm{s}\right)$} & Overall & $1,126.1$ & 0.0 & $0.0-4,469.2$ & $1,340.9$ \\
\hline & Day & $1,309.5$ & $1,810.5$ & $0.0-4,469.2$ & $1,287.7$ \\
\hline & Night & 856.1 & 0.0 & $0.0-4,466.9$ & $1,372.1$ \\
\hline \multirow[t]{3}{*}{ Spillway $\left(\mathrm{ft}^{3} / \mathrm{s}\right)$} & Overall & $1,265.0$ & $1,275.6$ & $0.0-7,453.4$ & $1,242.1$ \\
\hline & Day & $1,258.3$ & $1,286.0$ & $0.0-7,453.4$ & $1,174.4$ \\
\hline & Night & $1,275.0$ & $1,249.0$ & $0.0-7,183.6$ & $1,335.8$ \\
\hline \multirow[t]{3}{*}{ Regulating outlet $\left(\mathrm{ft}^{3} / \mathrm{s}\right)$} & Overall & 3.4 & 0.0 & $0.0-2,642.2$ & 94.7 \\
\hline & Day & 1.1 & 0.0 & $0.0-2,642.2$ & 54.9 \\
\hline & Night & 6.7 & 0.0 & $0.0-2,641.2$ & 133.0 \\
\hline \multirow[t]{3}{*}{ Forebay elevation (feet) } & Overall & $1,557.2$ & $1,562.6$ & $1,519.1-1,565.0$ & 10.2 \\
\hline & Day & $1,557.9$ & $1,562.8$ & $1,519.3-1,565.0$ & 9.7 \\
\hline & Night & $1,556.2$ & $1,562.3$ & $1,519.1-1,565.0$ & 10.9 \\
\hline \multirow[t]{3}{*}{ Water temperature (degrees Celsius) } & Overall & 11.0 & 10.5 & $3.7-21.8$ & 5.1 \\
\hline & Day & 11.3 & 10.8 & $3.7-21.8$ & 5.1 \\
\hline & Night & 10.5 & 10.0 & $3.7-21.1$ & 5.2 \\
\hline \multirow[t]{3}{*}{ Percent spill of total } & Overall & 57.7 & 57.7 & $0.0-100.0$ & 43.0 \\
\hline & Day & 52.8 & 43.9 & $0.0-100.0$ & 42.8 \\
\hline & Night & 66.6 & 100.0 & $0.0-100.0$ & 42.1 \\
\hline \multirow[t]{3}{*}{ Percent RO of total } & Overall & 0.0 & 0.0 & $0.0-34.2$ & 1.2 \\
\hline & Day & 0.0 & 0.0 & $0.0-21.8$ & 0.5 \\
\hline & Night & 0.1 & 0.0 & $0.0-34.2$ & 1.8 \\
\hline
\end{tabular}




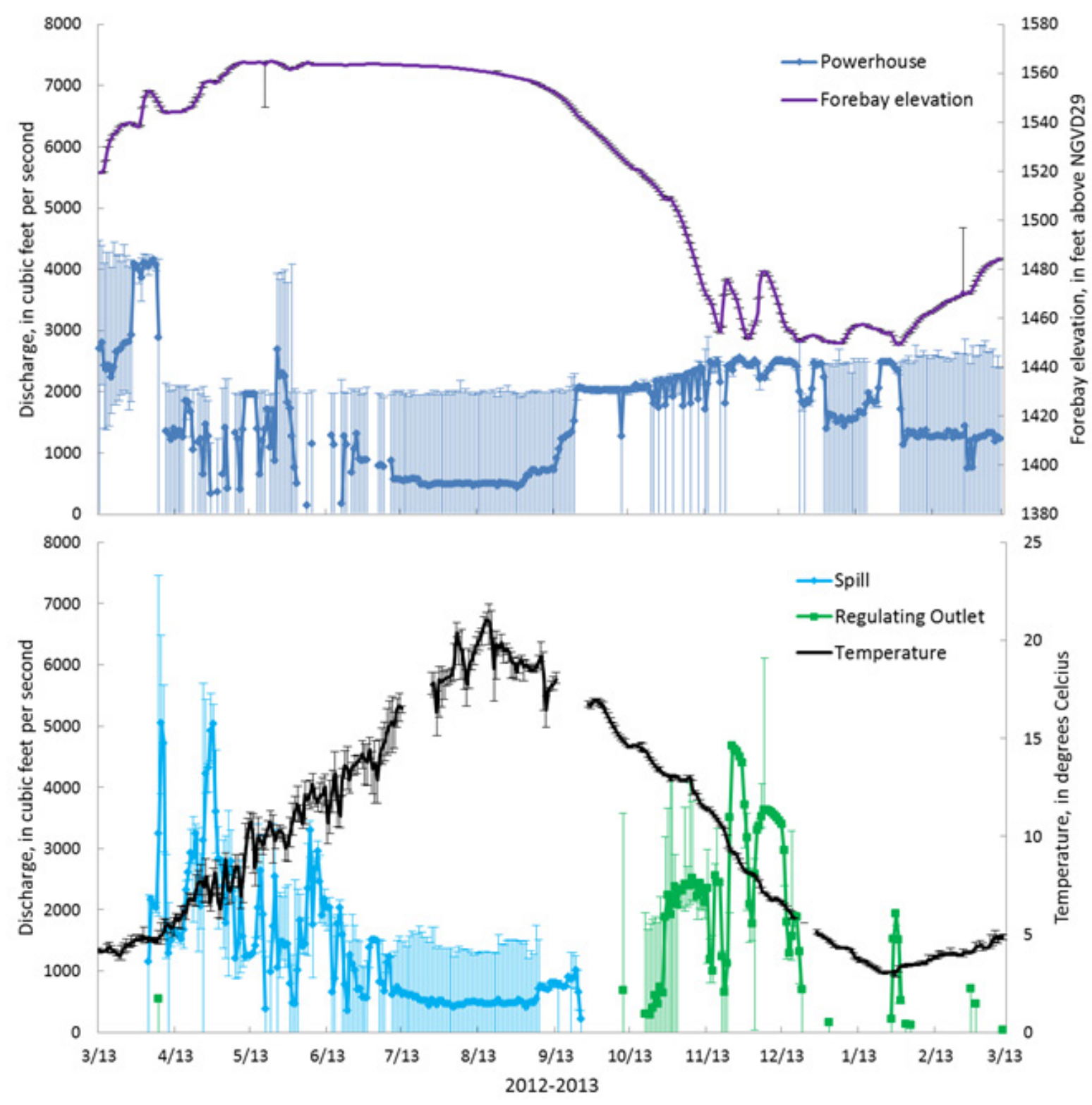

Figure 9. Graphs showing mean daily discharge (Powerhouse, Spill, Regulating Outlet), forebay elevation, and average water temperature of the upper 20 feet of the forebay at Detroit Dam, Oregon, during the 2012 spring and fall study periods. Whiskers indicate daily minimums and maximums. 

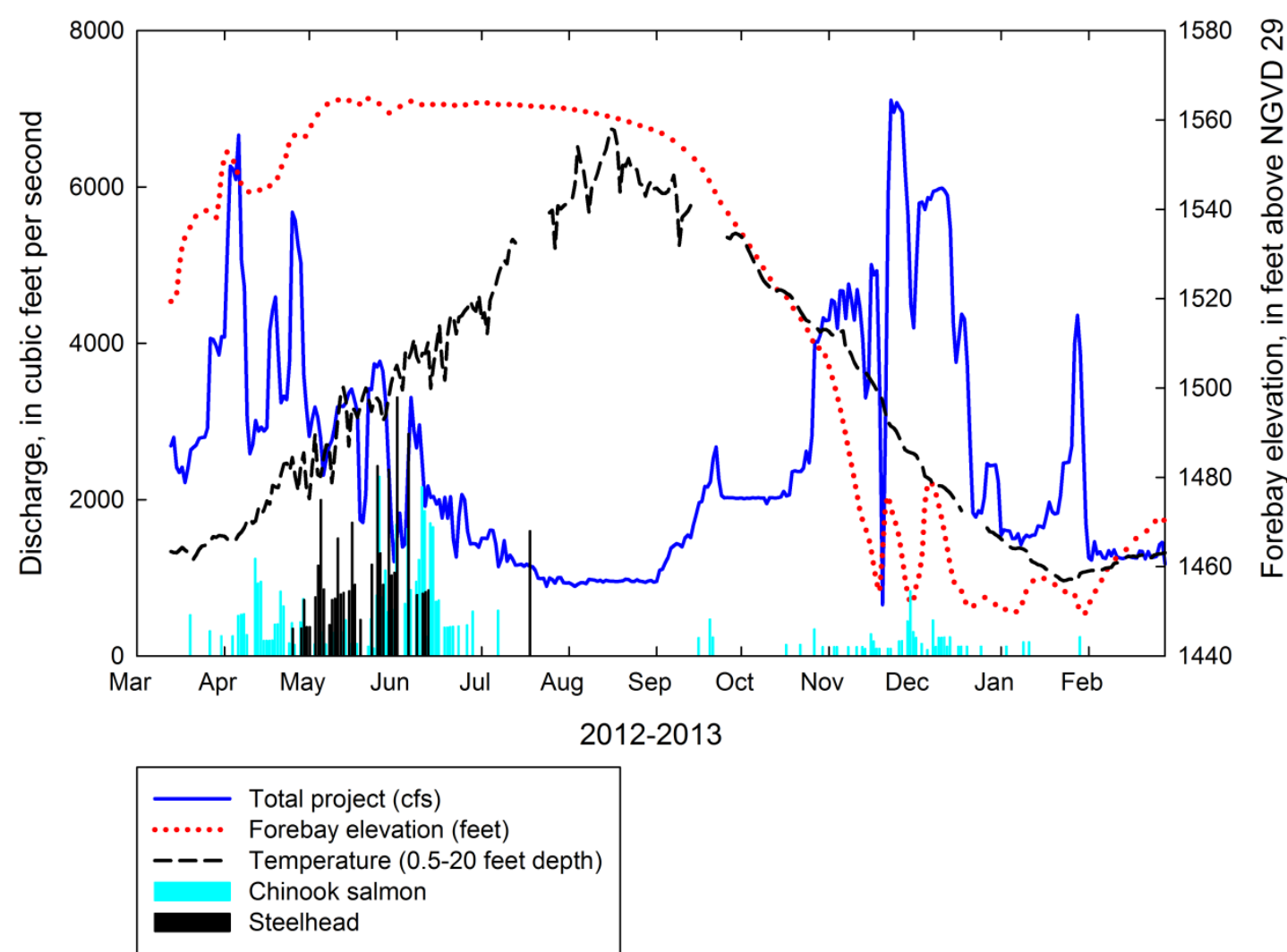

Figure 10. Graph showing daily mean dam operations and environmental conditions at Detroit Reservoir, Oregon, from March 13, 2012, through February 21, 2013, when fish were detected in the study area. Fish passage (blue and black vertical bars) is plotted as percentage of fish passing out of the number of fish available to pass.

During the fall study period, most project discharge passed through the powerhouse and regulating outlet routes, and the spillway rarely was used. Total project discharge generally was higher in November, December, and January than during the rest of the period and had several peaks. Hourly total project discharge ranged from 0.0 to $7,183.0 \mathrm{ft}^{3} / \mathrm{s}$ with a mean of $2,941.2 \mathrm{ft}^{3} / \mathrm{s}$ (table 4). Turbineonly operations constituted nearly one-half of the fall operating conditions, whereas turbine plus spill occurred during 34.5 percent of the period (figs. 9 and 10). There was no project discharge 10.1 percent of the time. The remaining 9.25 percent of the time was a mix of regulating outlet only, spill only, and turbine plus spill. During the fall study period, the mean powerhouse discharge was $1,919.9 \mathrm{ft}^{3} / \mathrm{s}$ (range $0.0-2,898.4 \mathrm{ft}^{3} / \mathrm{s}$ ), and the powerhouse was operated 89.30 percent of the period with slightly more time during the night (56.23 percent) than during the day (43.77 percent). Spill continued intermittently until September 23 when the forebay elevation decreased below the elevation of the spill ogee as part of the winter drawdown for flood control. Regulating outlet number 1, the uppermost and middle of the three outlets, operated intermittently, but daily, from October 19 through December 21, 2012, and then intermittently in January, February, and March 2013. Mean discharge through the regulating outlet was 
$966.0 \mathrm{ft}^{3} / \mathrm{s}$ (range $0.0-4,744.6 \mathrm{ft}^{3} / \mathrm{s}$ ) (table 4). Forebay elevation decreased steadily to $1,454 \mathrm{ft}$ until November 19. Minimum conservation pool (1,450 ft) was reached on December 21, and the forebay elevation fluctuated with inflow until early February when the pool began to fill. Water temperature in the top $20 \mathrm{ft}$ of the reservoir decreased from $17.8^{\circ} \mathrm{C}$ on September 12,2012 , to $3.0^{\circ} \mathrm{C}$ on January 22 , 2013, and then remained less than $4.8^{\circ} \mathrm{C}$ until the end of the period.

Weir spill occurred during the fall study period from September 21 at 3:00 p.m. until September 23 at 4:00 p.m.. Forebay elevation ranged from 1,544.5 to 1,542.0 ft. The powerhouse was on during the entire 49-h weir spill period and powerhouse discharge ranged from $1,760.0$ to $2,110.0 \mathrm{ft}^{3} / \mathrm{s}$. Mean spill discharge was $599.3 \mathrm{ft}^{3} / \mathrm{s}$ and ranged from 240 to $1,224 \mathrm{ft}^{3} / \mathrm{s}$. Spill occurred through one and two of the six bays.

Table 4. Mean hourly summary statistics of dam operations and environmental conditions at Detroit Dam and Reservoir, Oregon, from September 12, 2012, through February 21, 2013, when fall-released fish were detected in the study area.

[SD, standard deviation; RO, regulating outlet; $\mathrm{ft}^{3} / \mathrm{s}$, cubic foot per second]

\begin{tabular}{llrrrr}
\hline & Period & \multicolumn{1}{c}{ Mean } & Median & \multicolumn{1}{c}{ Range } & \multicolumn{1}{c}{ SD } \\
\cline { 2 - 5 } Total project $\left(\mathrm{ft}^{3} / \mathrm{s}\right)$ & Overall & $2,941.2$ & $2,458.2$ & $0.0-7,183.0$ & $1,788.9$ \\
& Day & $3,030.0$ & $2,473.5$ & $0.0-7,183.0$ & $1,622.8$ \\
& Night & $2,877.3$ & $2,439.7$ & $0.0-7,161.4$ & $1,897.3$ \\
Powerhouse $\left(\mathrm{ft}^{3} / \mathrm{s}\right)$ & Overall & $1,919.9$ & $2,218.8$ & $0.0-2,898.4$ & 826.5 \\
& Day & $2,015.2$ & $2,219.1$ & $0.0-2,898.4$ & 706.0 \\
& Night & $1,851.3$ & $2,217.0$ & $0.0-2,767.8$ & 897.2 \\
Spillway $\left(\mathrm{ft}^{3} / \mathrm{s}\right)$ & Overall & 55.9 & 0.0 & $0.0-1,307.4$ & 211.5 \\
& Day & 70.0 & 0.0 & $0.0-1,305.1$ & 231.4 \\
& Night & 45.8 & 0.0 & $0.0-1,307.4$ & 195.3 \\
Regulating outlet $\left(\mathrm{ft}^{3} / \mathrm{s}\right)$ & Overall & 966.0 & 0.0 & $0.0-4,744.6$ & $1,422.8$ \\
& Day & 944.9 & 0.0 & $0.0-4,744.6$ & $1,442.6$ \\
Forebay elevation $(f e e t)$ & Night & 981.1 & 0.0 & $0.0-4,731.3$ & $1,408.6$ \\
& Overall & $1,483.0$ & $1,466.7$ & $1,449.1-1,553.0$ & 33.7 \\
& Day & $1,486.5$ & $1,468.6$ & $1,449.1-1,553.0$ & 35.1 \\
Water temperature $($ degrees Celsius) & Night & $1,480.6$ & $1,465.2$ & $1,449.1-1,553.0$ & 32.5 \\
& Overall & 8.3 & 7.1 & $2.8-18.4$ & 4.6 \\
& Day & 8.9 & 8.1 & $3.0-18.4$ & 4.8 \\
& Night & 7.9 & 6.8 & $2.8-18.2$ & 4.3 \\
& Overall & 4.2 & 0.0 & $0.0-100.0$ & 17.3 \\
& Day & 3.4 & 0.0 & $0.0-100.0$ & 12.8 \\
& Night & 4.7 & 0.0 & $0.0-100.0$ & 20.2 \\
& Overall & 22.0 & 0.0 & $0.0-100.0$ & 28.3 \\
& Day & 20.7 & 0.0 & $0.0-100.0$ & 29.3 \\
& Night & 23.1 & 0.0 & $0.0-100.0$ & 27.4 \\
\hline
\end{tabular}




\section{Movements within the Reservoir}

\section{General Fish Behavior}

Most fish released in the tributaries were subsequently detected in the reservoir, but a lower percentage of steelhead were detected in the reservoir than Chinook salmon. During the spring study period, 12.0 percent (56 of 468) of the Chinook salmon and 38.5 percent ( 77 of 200) of the steelhead were undetected after release within the 90th percentile of their tag life. During the fall study period, 9.9 percent of the Chinook salmon (51 of 514) were undetected after release within the 90th percentile of their tag life. The undetected fish were from both release sites and most release groups (fig. 11). During the spring study period, the fish released at the Breitenbush River site constituted 59 percent of the undetected Chinook salmon and 56 percent of the undetected steelhead. During the fall study period, Chinook salmon released at the Breitenbush River site constituted 51 percent of the undetected fish.

Fish detected in the reservoir were present at all areas monitored and often made repeated trips from the head of the reservoir to the dam and back. General movements of several randomly selected fish are shown in figures 12 and 13. During the spring study period, Chinook salmon made more trips throughout the reservoir than steelhead, but steelhead often took longer to travel from the release sites to the reservoir (array 0 to array 1). During the spring study period, individual Chinook salmon made 1-23 trips from the log boom array or upstream to within $25 \mathrm{~m}$ of the dam. Individual steelhead made 1-18 trips from the log boom or upstream to within $25 \mathrm{~m}$ of the dam. The average number of trips to within $25 \mathrm{~m}$ of the dam was 2.7 for Chinook salmon and 2.8 for steelhead. During the fall study period, Chinook salmon made 1-28 trips from the log boom or upstream to within $25 \mathrm{~m}$ of the dam, with an average of 6 trips.
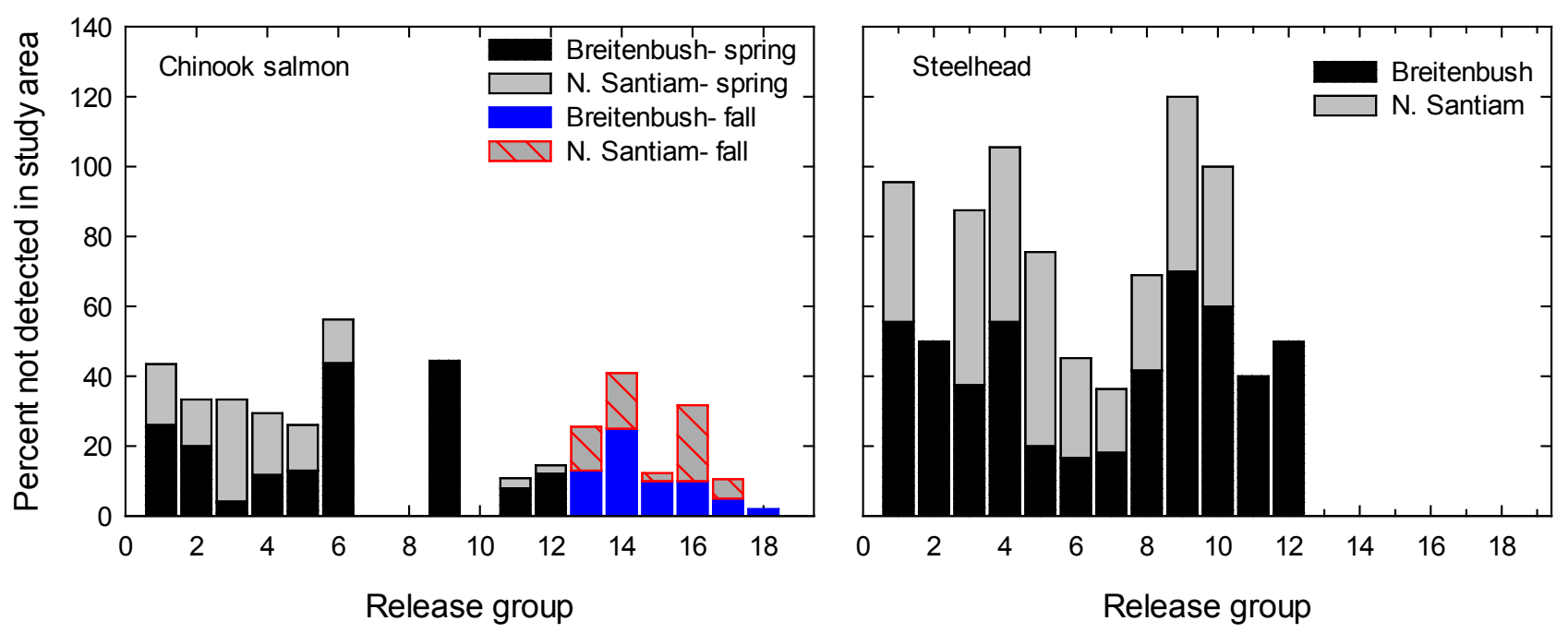

Figure 11. Graphs showing percentage of fish not detected at Detroit Dam and Reservoir, Oregon, during the 2012 spring and fall study periods. No juvenile Chinook salmon were released in release group seven or at North Santiam River in release group eight. Bars represent percentage of each release site for each release group. 

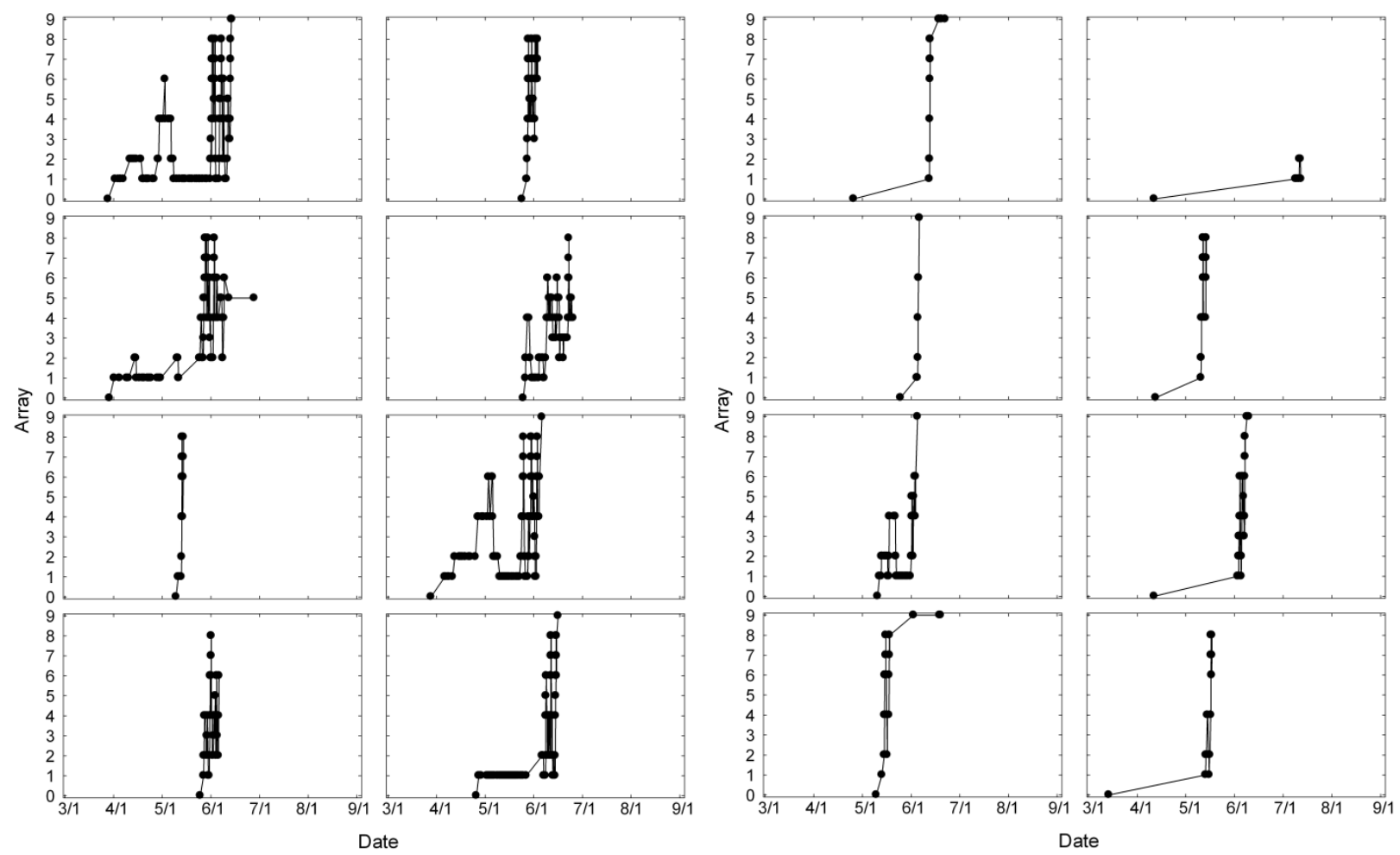

Figure 12. Graphs showing movements of eight randomly selected juvenile Chinook salmon (left 2 columns) and juvenile steelhead (right 2 columns) in Detroit Reservoir, Oregon, during the 2012 spring study period. Arrays represent hydrophone groups ranging from release (0) to Big Cliff Dam (9). Arrays 1-6 were in Detroit Reservoir as described in figure 3, array 7 was 200 feet upstream of Detroit Dam, and array 8 was at Detroit Dam. 


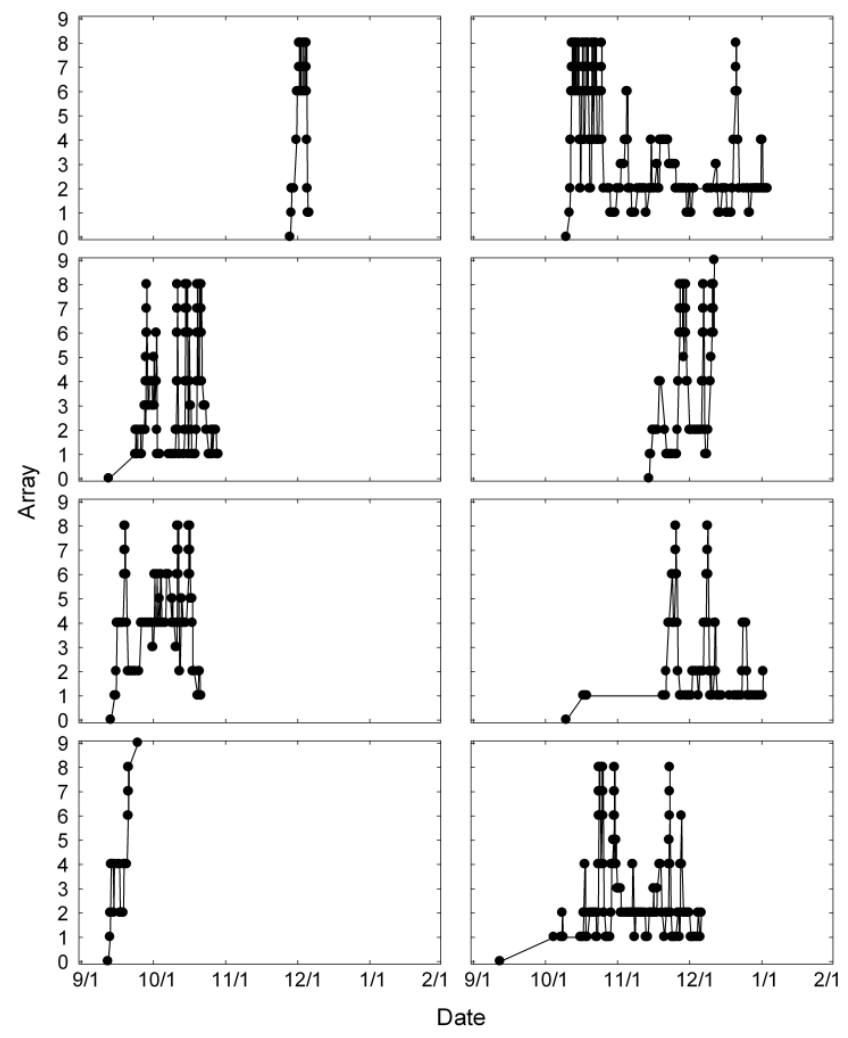

Figure 13. Graphs showing movements of eight randomly selected juvenile Chinook salmon in Detroit Reservoir, Oregon, during the 2012 fall study period. Arrays represent hydrophone groups ranging from release (0) to Big Cliff Dam (9). Arrays 1-6 were in Detroit Reservoir as described in figure 3, array 7 was 200 feet upstream of Detroit Dam, and array 8 was at Detroit Dam.

\section{Timing of Detection}

The distribution of arrival times of Chinook salmon and steelhead at detection arrays, an indicator of the timing of fish movements between arrays, differed subtlety between species and between the two study periods (fig. 14). During the spring study period, the hour of detection at most arrays was similarly distributed between the day and night hours for both species. However, there were notable exceptions to this pattern at the upstream (array 1) and downstream areas of the reservoir. Peaks in detections at the $\log$ boom (array 6) and at the dam occurred at about 9:00 a.m. for Chinook salmon and from 5:00 to 7:00 p.m. for steelhead. Peaks in detections of both species near the head of the reservoir began at about 6:00 p.m. . During the fall study period, Chinook salmon detections again were broadly distributed among the day and night hours, but were less variable than in the spring period. For Chinook salmon in the fall study period, there were minor increases in activity observed at the forebay line from 5:00 to 8:00 a.m. and at the Kinney Creek arm from 2:00 to 7:00 p.m. 

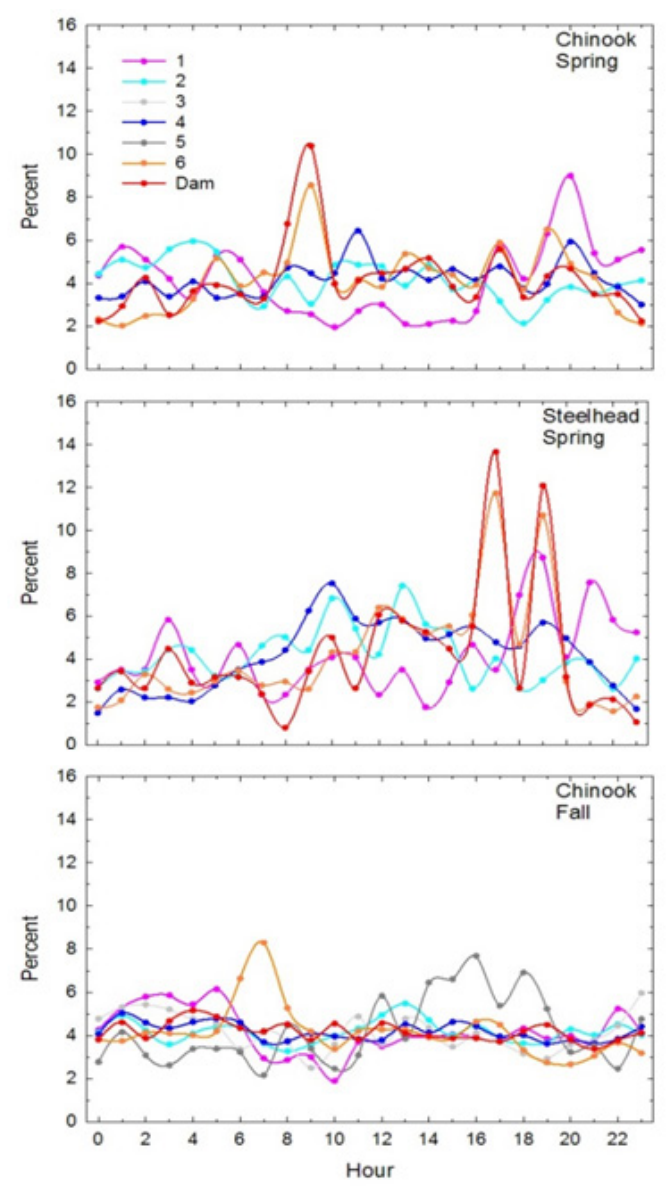

Figure 14. Graphs showing distributions of hourly arrival times of individual juvenile Chinook salmon and juvenile steelhead at detection arrays in Detroit Reservoir, Oregon, during the 2012 spring and fall study periods. Arrays 16 represent locations in Detroit Reservoir (from upstream to downstream, see fig. 3). Arrays 3 and 5 in the Blowout Creek and Kinney Creek arms, respectively, were not present for the entire spring study period and are not shown for that period.

\section{Travel Time from Release to the Detroit Dam and to Dam Passage}

Travel times varied by species, season, and location in Detroit Reservoir. During the spring study period, Chinook salmon traveled faster than steelhead between the release sites in the tributaries to the reservoir; the median travel time was $2.4 \mathrm{~d}$ for Chinook salmon and $41.2 \mathrm{~d}$ for steelhead (fig. 15). The percentage detected after release is represented in the minimum y-axis values in the "Release to Detroit Reservoir" graph in figure 15. During the spring study period, the travel time from first detection in the reservoir to detection at the log boom (array 6) was shorter for steelhead than for Chinook salmon (median $4.4 \mathrm{~d}$ versus $10.0 \mathrm{~d}$ ), and the time from the log boom to dam passage also was shorter for steelhead than for Chinook salmon (median $5.2 \mathrm{~d}$ versus $13.0 \mathrm{~d}$ ). During the fall study period, the travel time distributions of Chinook salmon from release to first detection in the reservoir (median $1.3 \mathrm{~d}$ ) and from first detection in the reservoir to detection at the log boom (median $8.6 \mathrm{~d}$ ) were similar to those of Chinook salmon during the spring study period. However, during the fall study period fewer Chinook salmon passed the dam than during the spring study period and those that did took longer to do so. 


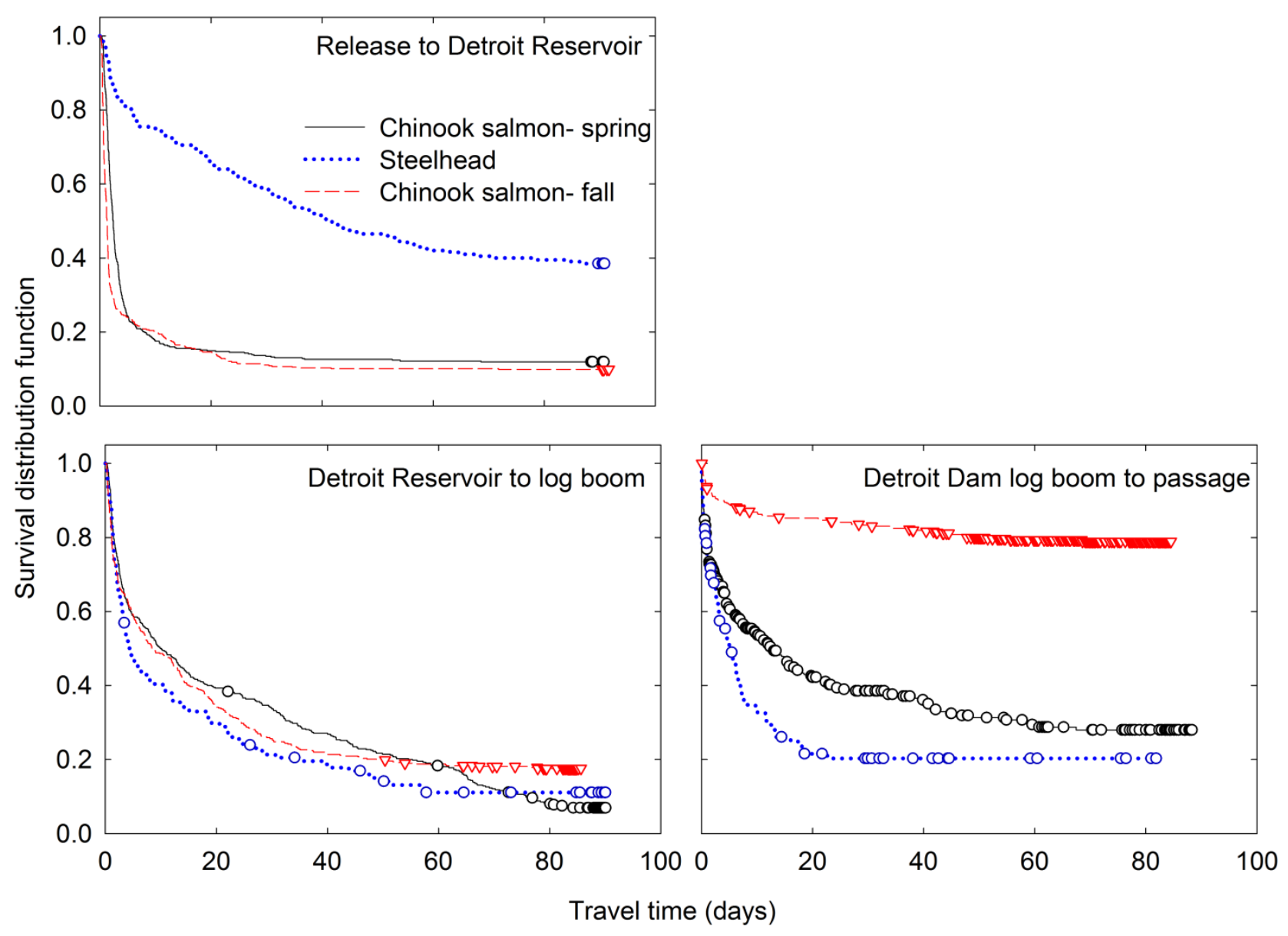

Figure 15. Survival distribution plots of travel times (days) at Detroit Dam and Reservoir, Oregon, during the 2012 spring and fall study periods. Observations are right-censored (open circles and open triangles) at the 90th percentile of tag life if no event occurred or at the last detection at the log boom if the passage route was unknown.

\section{Probability of Presence near Detroit Dam}

The probabilities of presence at each array and at Detroit Dam were based on the estimates from a single, highly-supported model, or the model-averaged estimates of multiple models with considerable support from the data. Two models of presence probability for Chinook salmon and four models for steelhead were evaluated in the spring study period, and four models for Chinook salmon were evaluated in the fall study period. These included models that assumed differences in recapture (detection) probabilities among reservoir arrays and models that assumed a common detection probability for all arrays. The median $\hat{c}$ procedure did not converge, likely due to the detection probabilities near 1.0 , so a $\hat{c}$ value of 1.00 was applied to the data.

In the suite of models of detection probabilities that were examined, only the model that assumed differences in detection probabilities among arrays received substantial support based on model weights for Chinook salmon in the spring study period (table 5, model 1). However, for steelhead in the spring study period and Chinook salmon in the fall study period, models that assumed differences in detection probabilities among arrays and models that assumed a common detection probability for all 
arrays both received substantial support (table 5, models 3-6). The detection probabilities ranged from 0.983 (SE 0.007) to 1.000 (SE 0.000) for Chinook salmon and from 0.993 (SE 0.006) to 1.000 (SE 0.000) for steelhead during the spring period, and from 0.998 (SE 0.002) to 1.000 (SE 0.000) among arrays during the fall study period. Models of presence that assumed different presence probabilities among arrays and models that assumed a common presence probability for all arrays were paired with each of the detection models supported by the data for each species and study period (tables 6-8).

Models of presence that assumed equal presence probabilities among arrays received considerably less support in comparison to models that assumed differences in presence probabilities among arrays for Chinook salmon and steelhead in the spring study period and Chinook salmon in the fall study period (tables 6-8). Data from Chinook salmon in the spring study period supported one model of presence probability (model 1, table 6), whereas data from steelhead in the spring study period and Chinook salmon in the fall study period supported two models (models 1 and 2, tables 7 and 8). Because multiple models of presence probability were supported for steelhead in the spring study period (table 7) and Chinook salmon in the fall study period (table 8), the estimates from models in each of these model suites with delta AICc values less than 10 were model-averaged.

The cumulative probability of being present at an array decreased as the distance from the release site increased, and estimates were higher for Chinook salmon during the spring and fall study periods than for steelhead in the spring study period (fig. 16). Trends in the estimates of cumulative probability of presence were similar but generally slightly lower during the fall study period than during the spring study period for Chinook salmon. The estimated cumulative probability that a Chinook salmon and a steelhead were present at Detroit Dam at least once during the spring study period was 0.767 (SE 0.020) and 0.535 (SE 0.035), respectively (fig. 16). During the fall study period, the Chinook salmon cumulative probability of presence at the dam was 0.710 (SE 0.020, fig. 16). The lower probability of steelhead presence at Detroit Dam was largely a result of the low probability of being detected in the reservoir after release.

Table 5. Suite of models of detection probabilities for the analysis of presence probabilities of juvenile Chinook salmon and steelhead released into tributaries upstream of Detroit Reservoir, Oregon, during the 2012 spring and fall period.

[Models of detection probability (P) include array or a common value fitted to all arrays (.). All models shared a common presence probability with an array effect. AICc is Akaike Information Criterion with an adjustment for effects of sample size. Num par is number of parameters. A c value of 1.000 was applied to all models]

\begin{tabular}{|c|c|c|c|c|c|c|}
\hline Model & AICc & $\begin{array}{l}\text { Delta } \\
\text { AlCc }\end{array}$ & $\begin{array}{c}\text { AlCc } \\
\text { weights }\end{array}$ & $\begin{array}{c}\text { Model } \\
\text { likelihood }\end{array}$ & $\begin{array}{c}\text { Num } \\
\text { par }\end{array}$ & Deviance \\
\hline \multicolumn{7}{|c|}{ - Chinook salmon - spring - } \\
\hline $1 \mathrm{P}($ array) & 931.660 & 0.000 & 0.997 & 1.000 & 8 & 2.183 \\
\hline $2 \mathrm{P}()$. & 943.445 & 11.785 & 0.003 & 0.003 & 6 & 17.993 \\
\hline & & ---- Ste & ad - spring - & & & \\
\hline $3 \mathrm{P}()$. & 441.394 & 0.000 & 0.624 & 1.000 & 6 & 14.532 \\
\hline 4 P(array) & 442.409 & 1.014 & 0.376 & 0.602 & 8 & 11.466 \\
\hline 5 P(array) & 1099.818 & 0.000 & 0.812 & 1.000 & 6 & 0.356 \\
\hline $6 \mathrm{P}()$. & 1102.829 & 3.011 & 0.180 & 0.222 & 6 & 3.367 \\
\hline
\end{tabular}


Table 6. Suite of models used in estimation of presence probabilities of juvenile Chinook salmon released into tributaries upstream of Detroit Reservoir, Oregon, during the 2012 spring study period.

[Models of presence probability (M) include array or a common value fitted to all arrays (.). AICc is Akaike Information Criterion with an adjustment for effects of sample size. Num. par is number of parameters. A c value of 1.000 was applied to the data]

\begin{tabular}{llrrrrr}
\hline \multicolumn{1}{c}{ Model } & AICc & \multicolumn{1}{c}{$\begin{array}{c}\text { Delta } \\
\text { AlCc }\end{array}$} & $\begin{array}{c}\text { AlCc } \\
\text { weights }\end{array}$ & $\begin{array}{c}\text { Model } \\
\text { likelihood }\end{array}$ & \multicolumn{1}{c}{$\begin{array}{c}\text { Num } \\
\text { par }\end{array}$} & Deviance \\
\hline $1 \mathrm{M}($ array), $\mathrm{P}($ array) & 931.660 & 0.000 & 1.000 & 1.000 & 8 & 2.183 \\
$2 \mathrm{M}(),. \mathrm{P}$ (array) & 978.861 & 47.201 & 0.000 & 0.000 & 4 & 57.427 \\
\hline
\end{tabular}

Table 7. Suite of models used in estimation of presence probabilities of juvenile steelhead released into tributaries upstream of Detroit Reservoir, Oregon, during the 2012 spring study period.

[Models of presence probability (M) include array or a common value fitted to all arrays (.). AICc is Akaike Information Criterion with an adjustment for effects of sample size. Num. par is number of parameters. A $\hat{c}$ value of 1.000 was applied to the data]

\begin{tabular}{lllcrrr}
\hline \multicolumn{1}{c}{ Model } & AICc & \multicolumn{1}{c}{$\begin{array}{c}\text { Delta } \\
\text { AlCc }\end{array}$} & $\begin{array}{c}\text { AlCc } \\
\text { weights }\end{array}$ & $\begin{array}{c}\text { Model } \\
\text { likelihood }\end{array}$ & $\begin{array}{c}\text { Num } \\
\text { par }\end{array}$ & Deviance \\
\hline $1 \mathrm{M}($ array), $\mathrm{P}()$. & 441.394 & 0.000 & 0.624 & 1.000 & 6 & 14.532 \\
$2 \mathrm{M}$ (array), P(array) & 442.409 & 1.014 & 0.376 & 0.602 & 8 & 11.466 \\
$3 \mathrm{M}(),. \mathrm{P}()$. & 575.050 & 133.655 & 0.000 & 0.000 & 2 & 156.283 \\
$4 \mathrm{M}(),. \mathrm{P}($ array $)$ & 575.427 & 134.033 & 0.000 & 0.000 & 4 & 152.624 \\
\hline
\end{tabular}

Table 8. Suite of models used in estimation of presence probabilities of juvenile Chinook salmon released into tributaries upstream of Detroit Reservoir, Oregon, during the 2012 fall study period.

[Models of presence probability (M) include array or a common value fitted to all arrays (.). AICc is Akaike Information Criterion with an adjustment for effects of sample size. Num. par is number of parameters. A $\hat{c}$ value of 1.000 was applied to the data]

\begin{tabular}{lccccrr}
\hline \multicolumn{1}{c}{ Model } & AICc & \multicolumn{1}{c}{$\begin{array}{c}\text { Delta } \\
\text { AlCc }\end{array}$} & $\begin{array}{c}\text { AlCc } \\
\text { weights }\end{array}$ & $\begin{array}{c}\text { Model } \\
\text { likelihood }\end{array}$ & $\begin{array}{c}\text { Num } \\
\text { par }\end{array}$ & Deviance \\
\hline $1 \mathrm{M}$ (array), $\mathrm{P}($ array) & 1099.818 & 0.000 & 0.812 & 1.000 & 6 & 0.356 \\
$2 \mathrm{M}$ (array), P(.) & 1102.829 & 3.011 & 0.180 & 0.222 & 6 & 3.367 \\
$3 \mathrm{M}(),. \mathrm{P}($ array) & 1109.429 & 9.611 & 0.007 & 0.008 & 2 & 17.995 \\
$4 \mathrm{M}(),. \mathrm{P}()$. & 1112.509 & 12.691 & 0.001 & 0.002 & 2 & 21.075 \\
\hline
\end{tabular}



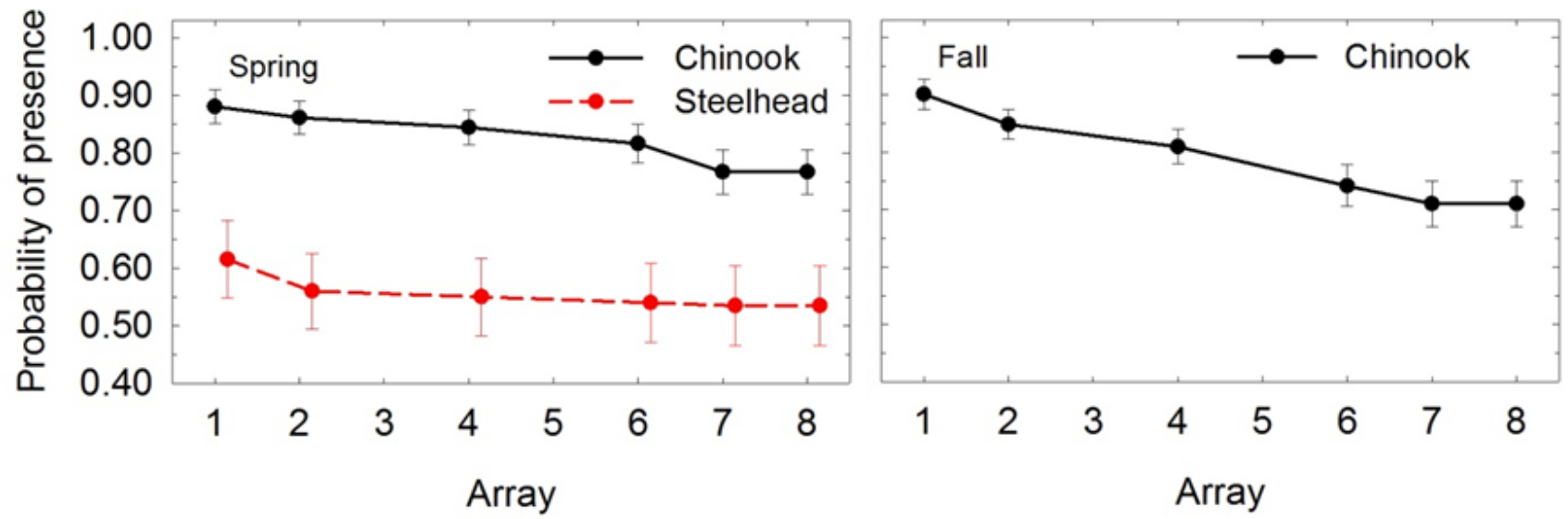

Figure 16. Graphs showing cumulative probabilities ( \pm 95 -percent confidence interval) of being present at least once at reservoir arrays 1, 2, 4, 6 (forebay line), and arrays 7 and 8 at Detroit Dam for fish released into tributaries upstream of Detroit Reservoir, Oregon, during the 2012 spring and fall study periods. Array 3 in the Blowout Creek arm and array 5 in the Kinney Creek arm were not used because fish can migrate to the dam without entering these areas.

\section{Movement Probabilities within the Reservoir}

Results of analyses of movement probabilities for Chinook salmon and steelhead between arrays in the reservoir indicated fish movements usually were directionally persistent (figs. 17 and 18; appendix tables A1 and A2). This means that fish moving upstream tended to continue in that direction until they reached the head of the reservoir and fish moving downstream tended to continue in that direction until they reached the dam. Movement probabilities of Chinook salmon and steelhead were estimated for 14 combinations of movements between adjacent reservoir arrays during the spring study period, and for 44 combinations of movements of Chinook salmon during the fall study period. Movements from Detroit Reservoir into the Blowout Creek and Kinney Creek arms were included in the fall study period, but not in the spring study period because these arrays were not present for much of the spring study period. Models of two-step Markov chains were supported over models of one-step Markov chains in 6 out 6 possible cases based on data from the spring study period and in 10 of the 12 possible cases based on data from the fall study period (appendix tables A3 and A4). A specific example of this directional movement from the spring study period is demonstrated by the higher probability that both Chinook salmon and steelhead moved downstream of array 2 to array 4 and then to array $6(0.62$ and 0.72 ), compared to the probability that these same fish moved downstream of array 2 to array 4 and then swam back upstream to array 2 (0.38 and 0.28; fig. 16; appendix table A1). 

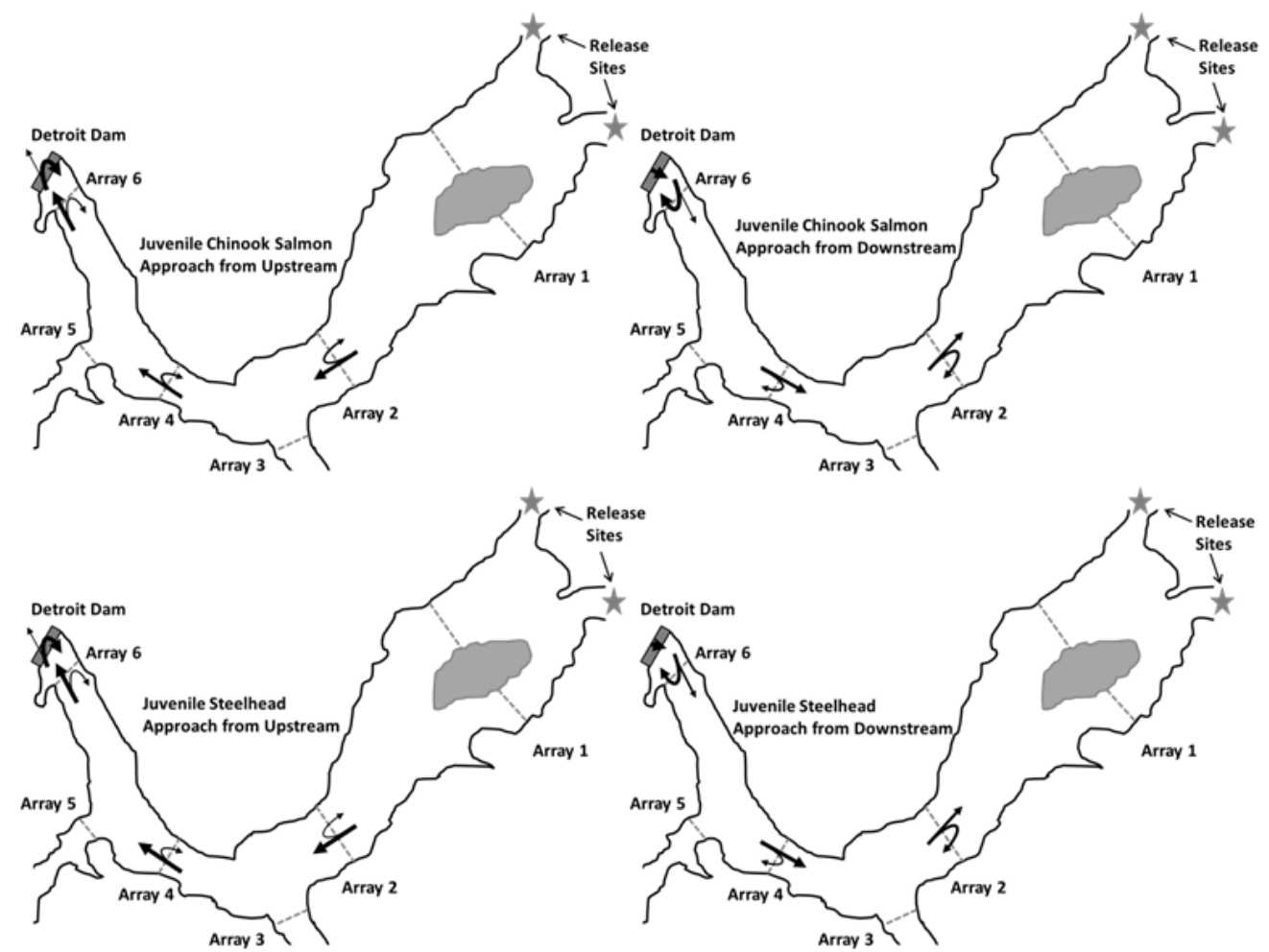

Figure 17. Movement probabilities of juvenile Chinook salmon and juvenile steelhead in Detroit Reservoir, Oregon, during the 2012 spring study period. Relative width of arrows indicates probabilities of moving from one array to an adjacent array based on the previous movement (wider is greater probability; see appendix table A1 for probabilities). Arrays 3 and 5 were not present for the entire season and were excluded from analysis.
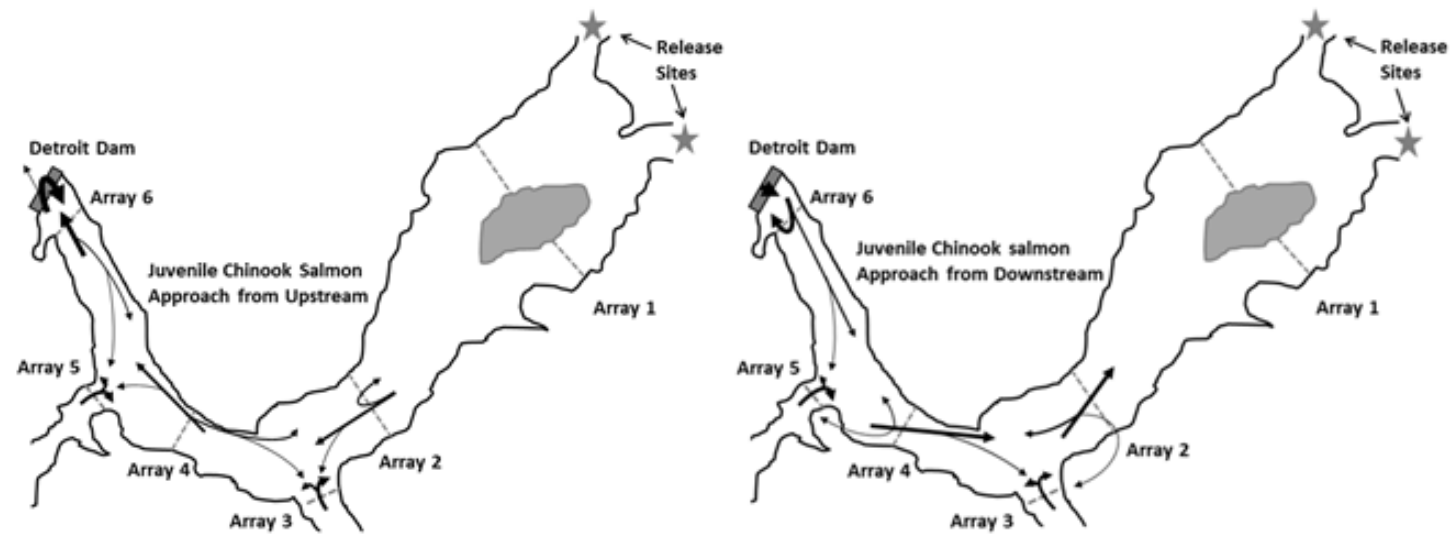

Figure 18. Movement probabilities of juvenile Chinook salmon in Detroit Reservoir, Oregon, during the 2012 fall study period. Relative width of arrows indicates probabilities of moving from one array to an adjacent array based on the previous movement (wider is greater probability; see appendix table A2 for probabilities). 
Exceptions to the prevalent upstream or downstream directional movements occurred near the dam during the spring study period and at the Kinney Creek arm (array 5) during the fall study period. During the spring study period, fish of each species near the forebay boundary (array 6) were more likely to move downstream to the dam irrespective of their previous locations (Chinook salmon, 0.720.77; steelhead, $0.62-0.72$ ). During the fall study period, Chinook salmon near the forebay boundary also were more likely to move downstream to the dam than upstream, but fish approaching the forebay boundary (log boom) that had previously been upstream near array 4 or the Kinney Creek arm (array 5) were more likely to do so than fish that had just come from the dam ( $0.74-0.81$ versus 0.69$)$. During the spring study period, out of the 1,453 Chinook salmon and 381 steelhead movements from the forebay boundary to the dam, the probability of a fish passing the dam during one of these events was 0.21 and 0.23 , respectively. In the fall study period, out of 3,367 Chinook salmon movements from the forebay boundary to the dam, the probability of a fish passing the dam was 0.03 . Chinook salmon leaving the Kinney Creek arm were more likely to move upstream to array $4(0.59)$ than downstream to the forebay boundary (0.41), and fish near the forebay boundary were unlikely to enter the Kinney Creek Arm (less than 0.04). In general, the probability that Chinook salmon moved into either the Blowout Creek or Kinney Creek arm during the fall study period was low (Blowout Creek: 0.10-0.24, Kinney Creek: 0.03-0.22), but over the entire fall period, 65.8 percent of the fish that entered the reservoir were detected in the Blowout Creek arm and 53.9 percent were detected in the Kinney Creek arm at least once.

\section{Behavior of Fish near the Dam}

Tagged fish commonly were detected throughout the area monitored within $105 \mathrm{~m}$ of the dam and made more trips into the area during the fall study period than during the spring study period. Migration behavior often was persistent in the downstream direction as fish approached the dam and variable when fish were near the dam, where they repeatedly traveled along the face of the dam prior to returning upstream. The positions of individual fish in figures 19-21 are all locations of the selected fish within the monitored area during the conditions shown. During the spring study period, most of the fish shown made several trips to the dam, but during the fall study period, they made as many as 22 trips, suggesting that they were less able to locate a route downstream. 


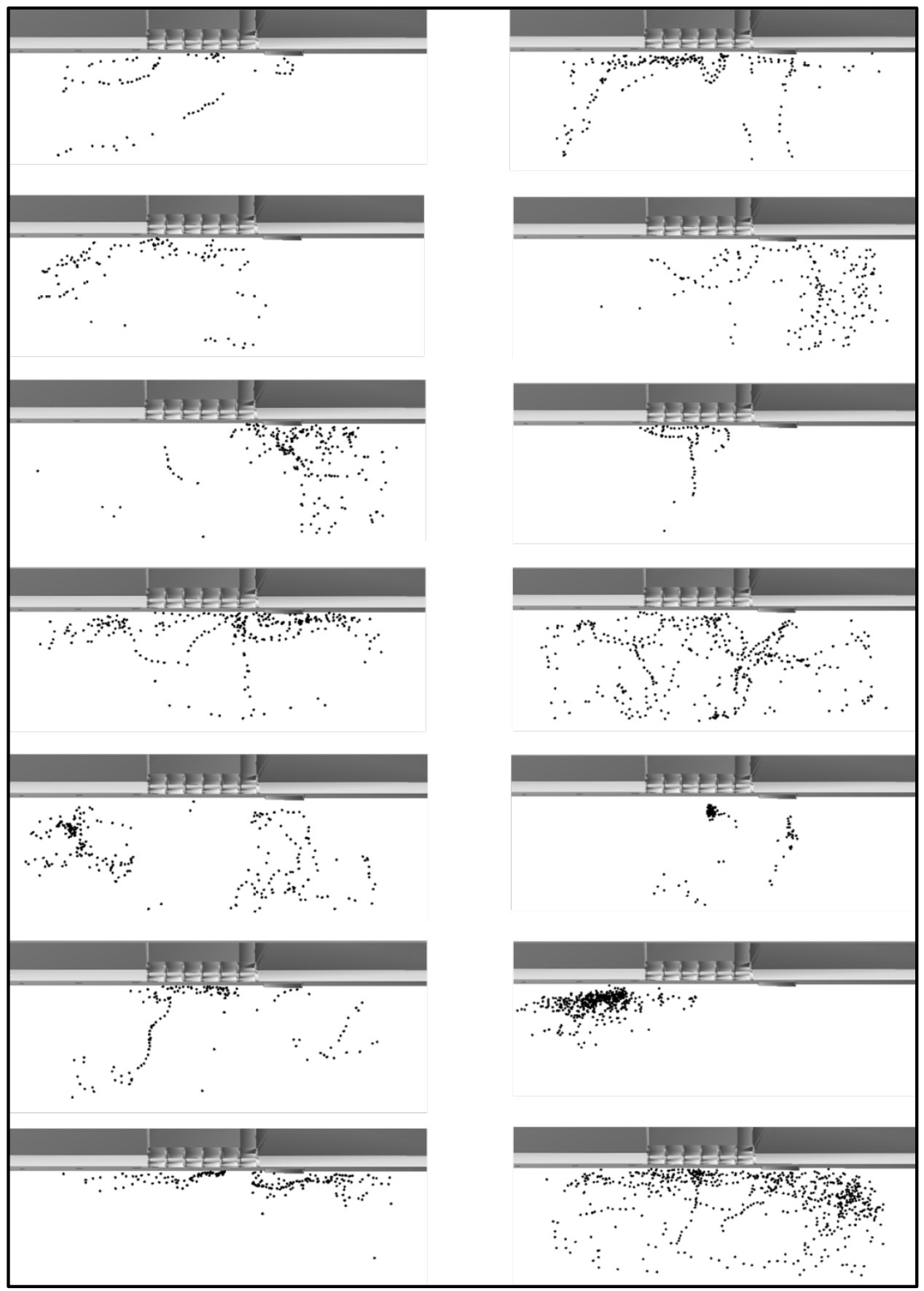

Figure 19. Position estimates of randomly selected juvenile Chinook salmon within 105 meters of Detroit Dam, Oregon, during the 2012 spring study period. Plots on the left show fish positions during the spillway only condition, and plots on the right show fish positions during the spillway plus powerhouse condition. Data are from tag codes (top down) G7203AF1B, G72046D03, G7205C1CB, G72082A8B, G72089BE7, G720A2CC7, and G7205AEEF on the left, and G720358EC, G7203B61A, G72056E25, G72065BF1, G720A2F25, G720C3E4C, and G72097256 on the right. 


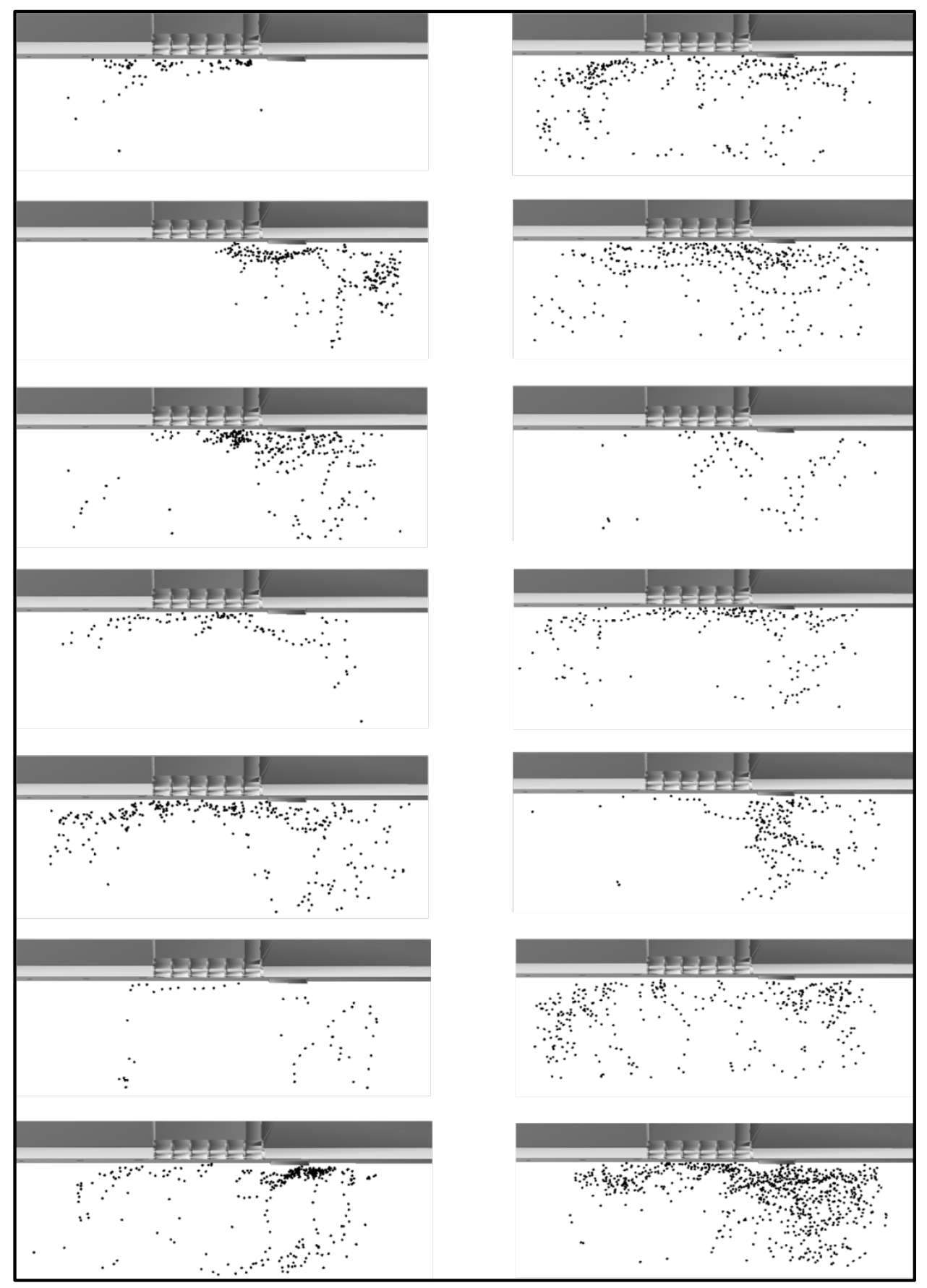

Figure 20. Position estimates of randomly selected of juvenile steelhead within 105 meters of Detroit Dam, Oregon, during the 2012 spring study period. Plots on the left show fish positions during the spillway only condition, and plots on the right show fish positions during the spillway plus powerhouse condition. Data are from tag codes (top down) G7204FA91, G7207975C, G7205E66B, G720AEFEF, G72056C99, G72079F9E, and G72083557 in the right and G720275F6, G72046C5D, G72056B1A, G7206358B, G7206E25F, G7209FF27, and G720A9E49 on the left. 


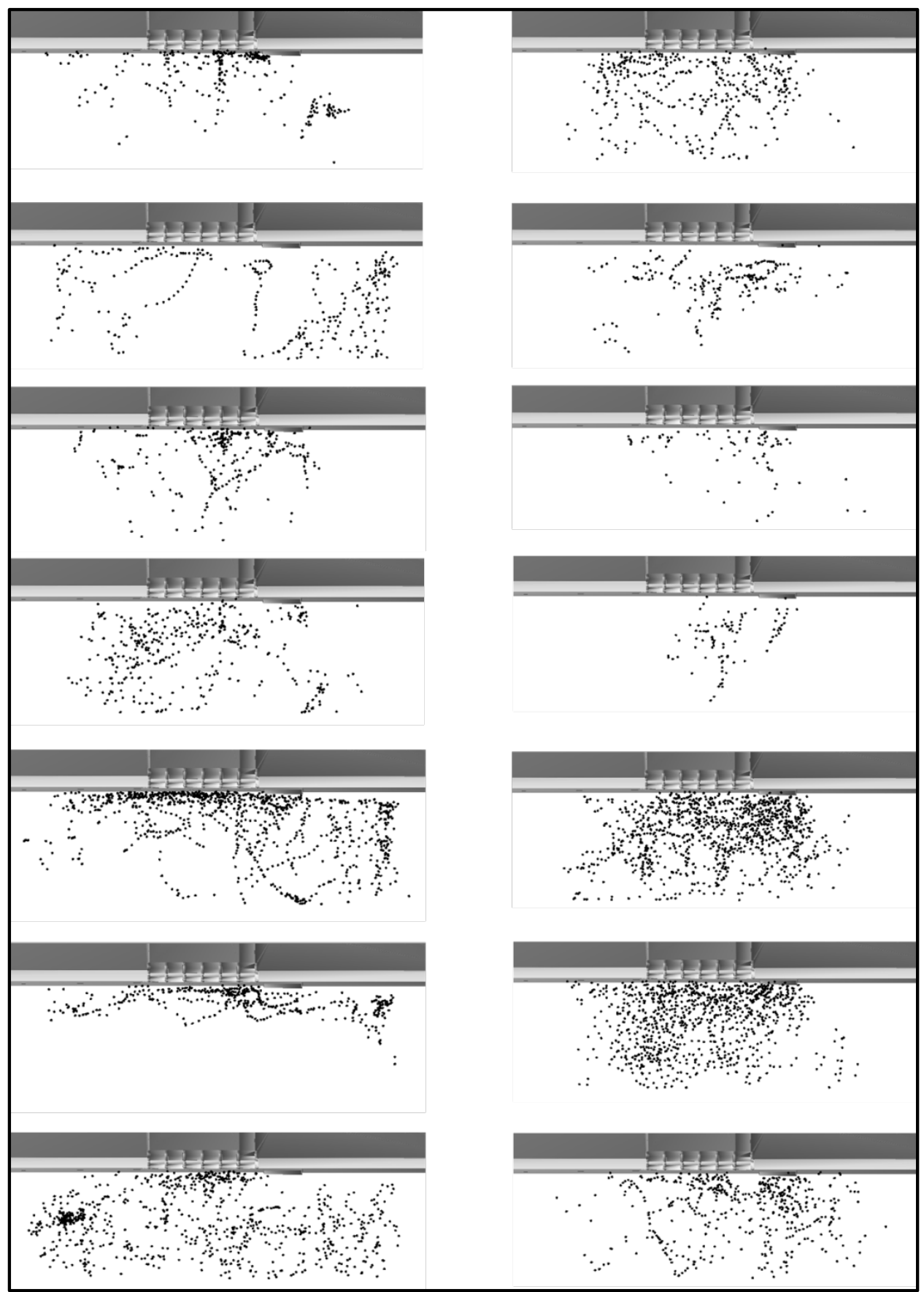

Figure 21. Position estimates of randomly selected juvenile Chinook salmon within 105 meters of Detroit Dam, Oregon, during the 2012 fall study period when the pool elevation was less than 1,525 ft. Plots on the left show fish positions during the powerhouse only condition, and plots on the right show fish positions during the spill (regulating outlet) plus powerhouse condition. Data are from tag codes (top down) G721958E7, G7277A4B6, G72063C17, G723EDE19, G727CODA6, G72447499 and G72444427 on the left, and G727983CA, G7279B5A9, G724430BE, G720FD973, G7232E628, G7263935C, and G7277FF4D on the right. 
The distribution of tagged fish within $105 \mathrm{~m}$ from the dam during the spring study period varied with distance from the dam, species, and dam operating conditions. During the spring study period, both species were more concentrated near the dam during the spillway only operation than they were during the spillway plus powerhouse operation (fig. 22). The areas of peak presence generally were similar between species and included areas near the dam upstream of the spillway and powerhouse penstocks. Tagged fish were present to a greater extent farther upstream of the powerhouse when it was operated than when the spillway was the only route operated. Steelhead were at shallower depths than Chinook salmon, but depths of both species varied enough that the difference is not obvious in the percent presence data (fig. 23).

\section{Juvenile Chinook}
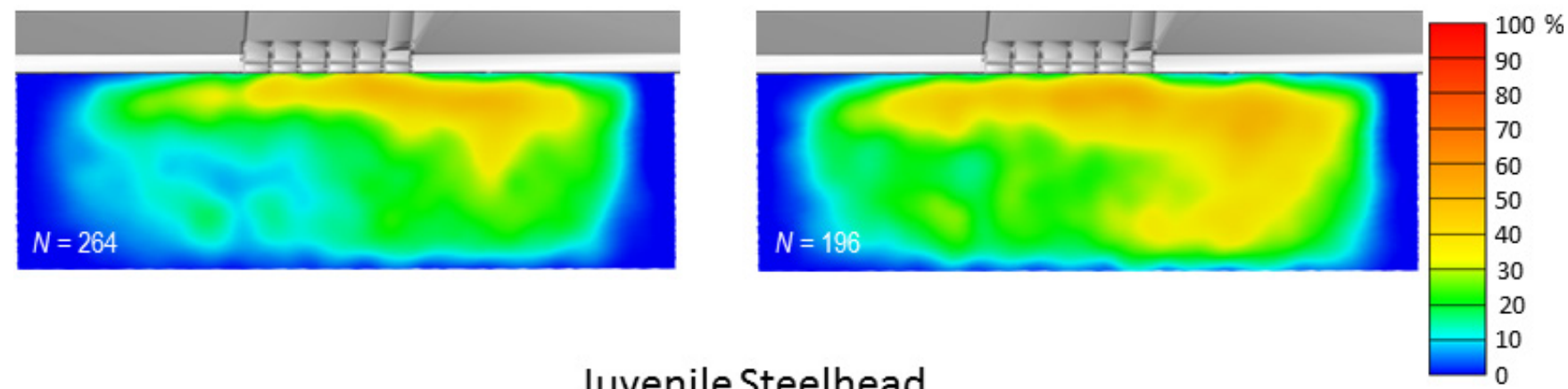

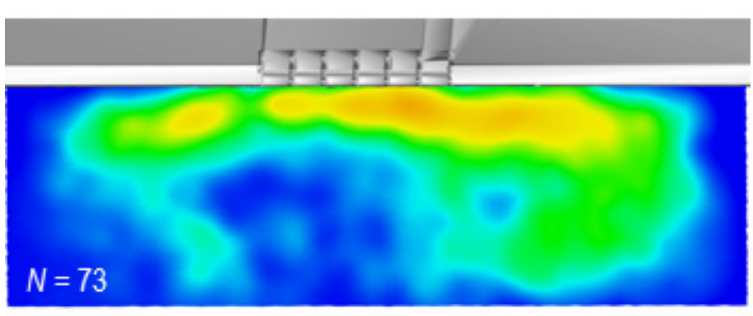

Spill only operation
Juvenile Steelhead

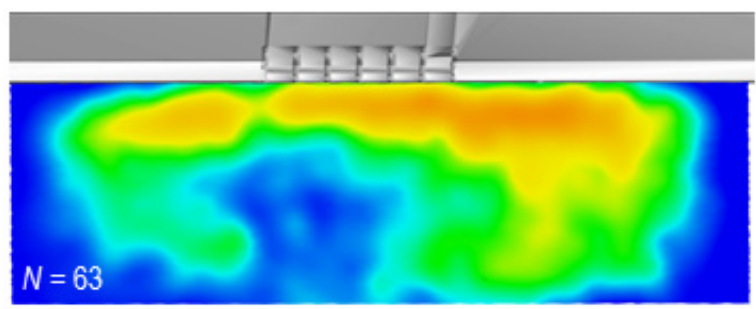

Spill plus powerhouse operation

Figure 22. Distributions of the percent presence of juvenile Chinook salmon and juvenile steelhead in $10 \times 10$ meter cells along the $x-y$ plane within 105 meters of Detroit Dam, Oregon, during the 2012 spring study period. Spill indicates water passed over the spillway. Sample sizes $(N)$ are numbers of fish represented. 

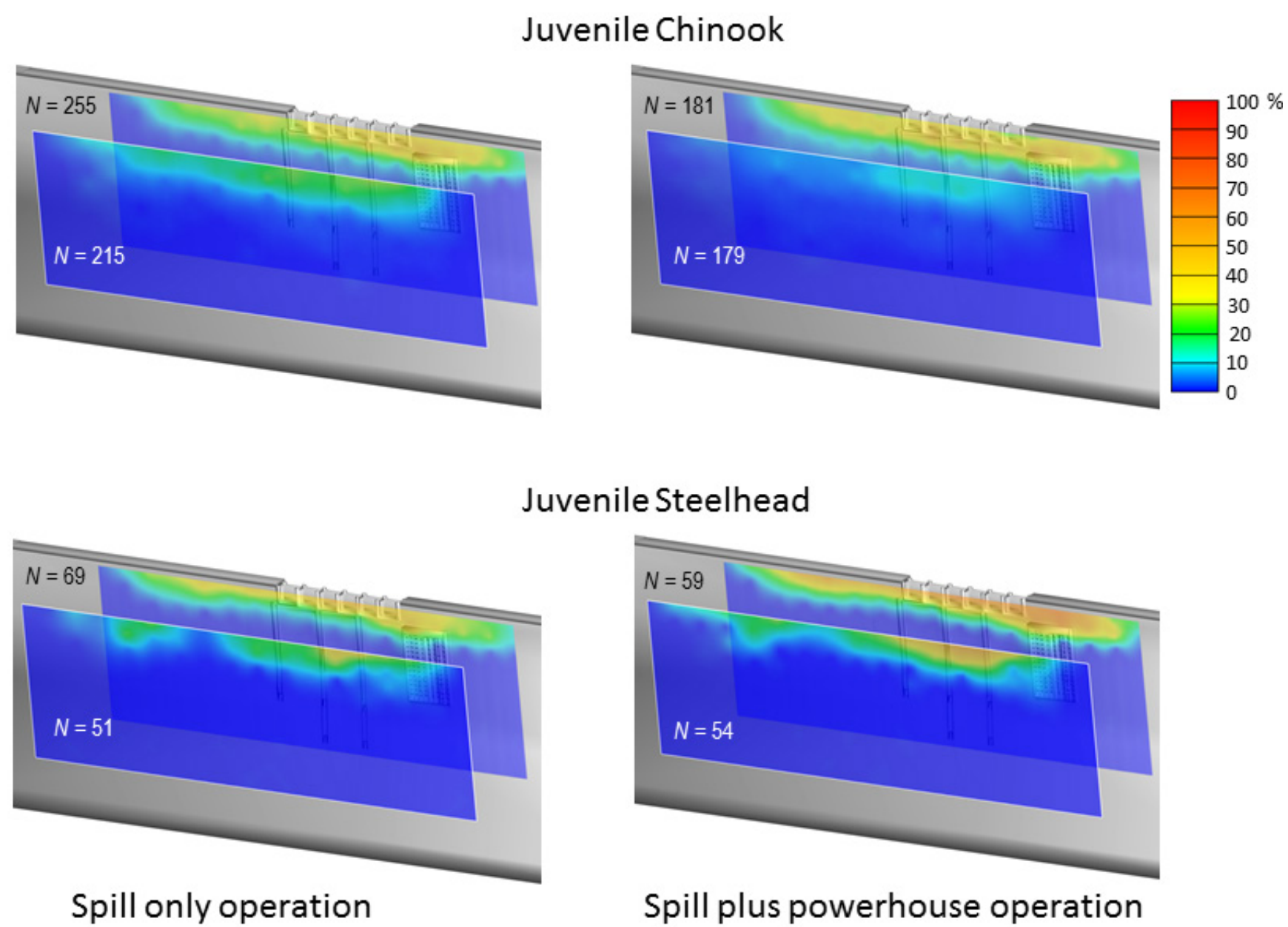

Figure 23. Distributions of the percent presence of juvenile Chinook salmon and juvenile steelhead in $20 \times 10$ meter cells along the $x-z$ plane at Detroit Dam, Oregon, during the 2012 spring study period. Distributions of fish in the 0-20 and 80-100 meter distance ranges from Detroit Dam are shown. Sample sizes $(N)$ are numbers of fish represented. 
The horizontal distributions of the tagged fish during the fall study period varied with the operating conditions and reservoir elevation. The few tagged fish present when the reservoir was nearly full were most concentrated in the horizontal plane near the routes in operation, and the peak percent presence was near the dam during both the spill only and spill plus powerhouse operating conditions (fig. 24A). When the reservoir elevation was about midway between the maximum and minimum conservation pool, the tagged fish were most concentrated during the spill plus powerhouse operation and often were present throughout much of the monitored area (fig. 24B). At the minimum conservation pool elevation, the tagged fish present during the spill only operation (regulating outlet) were most concentrated slightly upstream of the dam, whereas the tagged fish present during the spill plus powerhouse operation were concentrated throughout the monitored area upstream of the spillway and powerhouse (fig. 24C). The vertical distributions of the tagged fish during the fall study period varied with the forebay elevation and generally were similar between operating conditions (fig. 25).

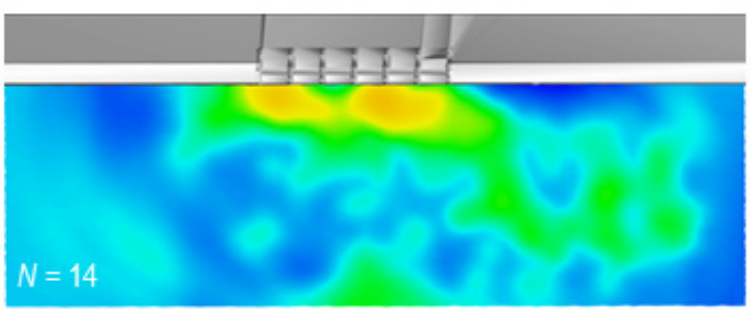

A
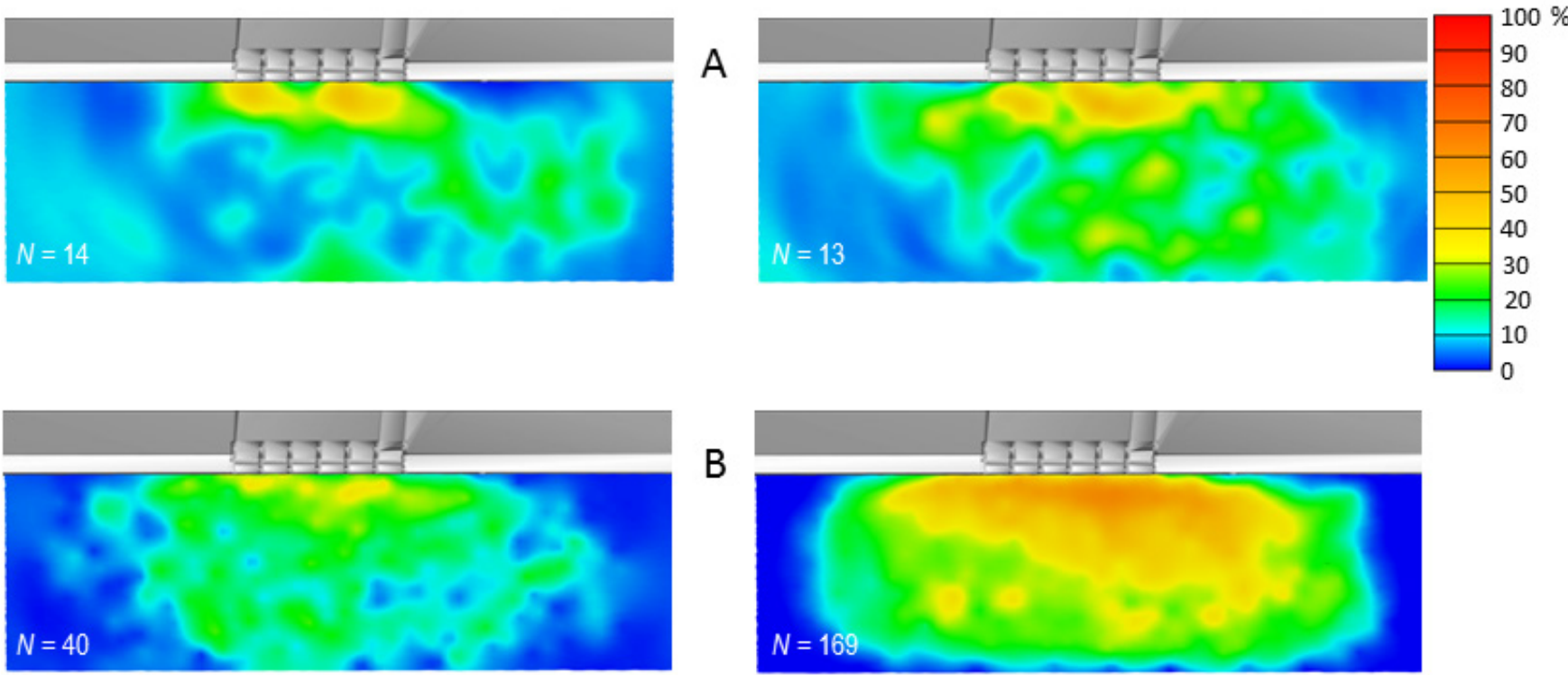

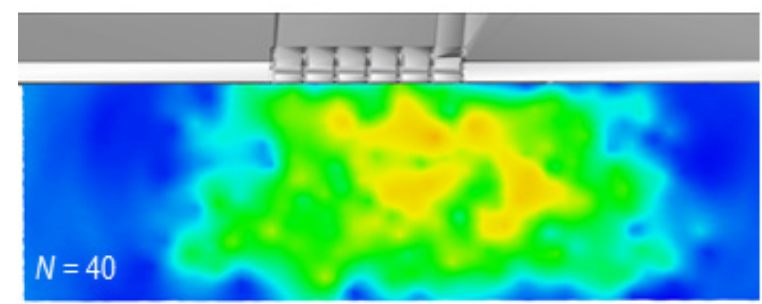

Spill only operation

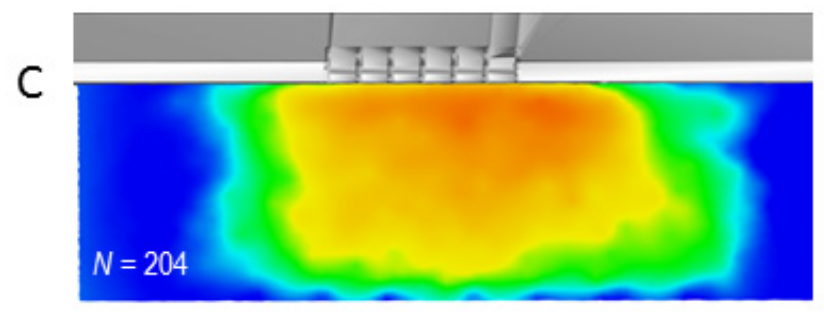

Spill plus powerhouse operation

Figure 24. Distributions of the percent presence of juvenile Chinook salmon and juvenile steelhead in $10 \times 10$ meter cells along the $x-y$ plane within 105 meters of Detroit Dam, Oregon, during the 2012 fall study period. Data from forebay elevations of 1,565 feet (A), 1,509 feet (B), and 1,450 feet (C) are shown. Spill was through the spillway in $(A)$ and the regulating outlet in $(B)$ and $(C)$. Sample sizes $(N)$ are numbers of fish represented. 

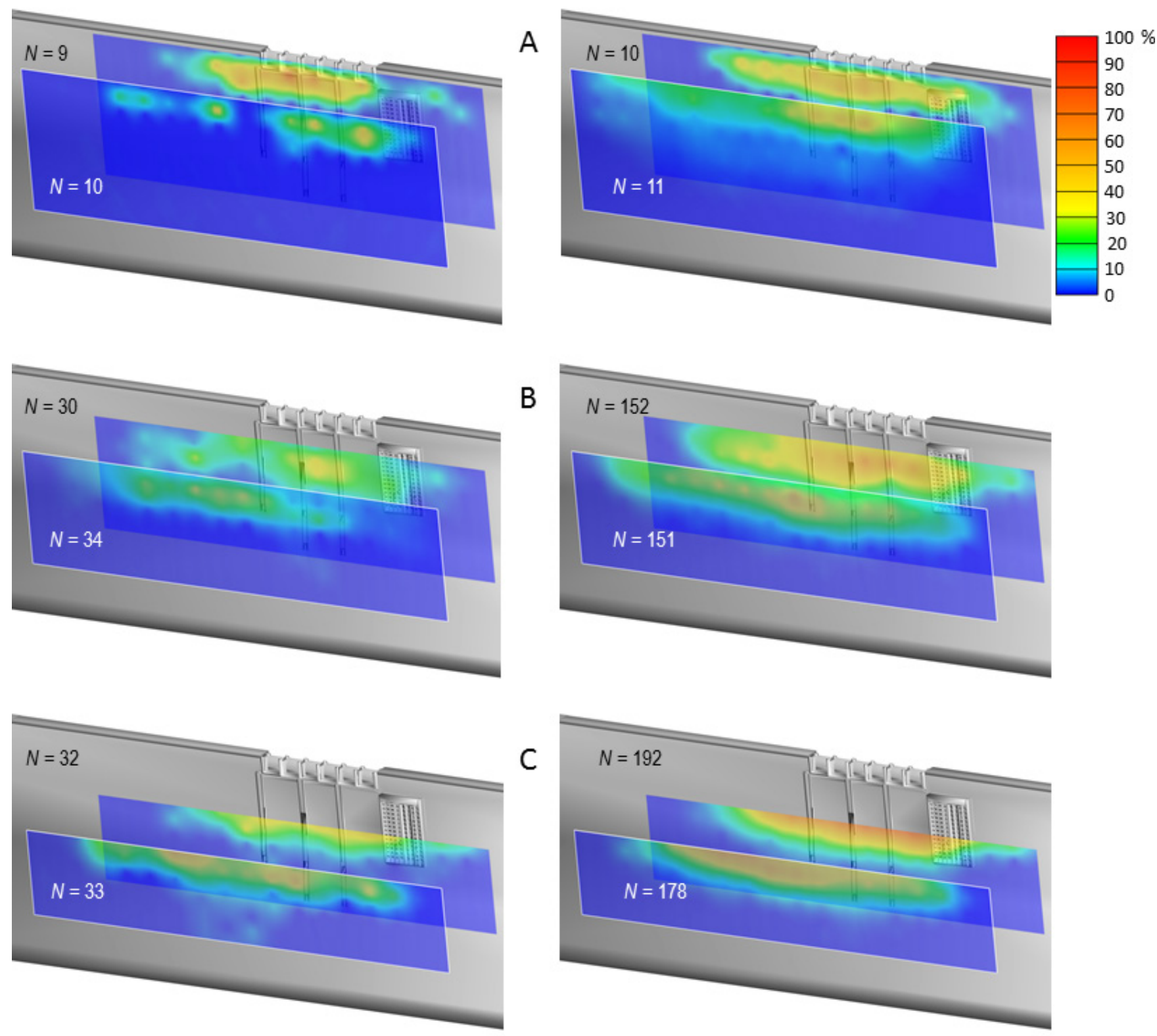

Spill only operation

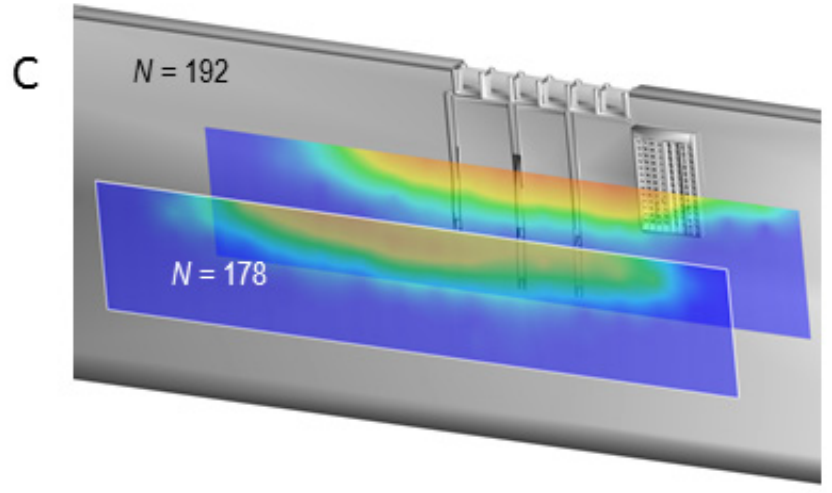

Spill plus powerhouse operation

Figure 25. Distributions of the percent presence of juvenile Chinook salmon and juvenile steelhead in $20 \times 10$ meter cells along the $x-z$ plane at Detroit Dam, Oregon, during the 2012 fall study period. Distributions of fish in the 0-20 and 80-100 meter distance ranges from Detroit Dam during forebay elevations of 1,565 feet (A), 1,509 feet $(B)$, and 1,450 feet $(C)$ are shown. Spill was through the spillway in $(A)$ and the regulating outlet in $(B)$ and $(C)$. Sample sizes $(N)$ are numbers of fish represented. 
Depths of tagged fish within $25 \mathrm{~m}$ of the dam varied between species, reservoir elevation, and diel period (fig. 26). When the reservoir elevation was greater than the spillway ogee of $1,541 \mathrm{ft}$ during the spring study period, the mean hourly depths of Chinook salmon ranged from 10.4 to $29.1 \mathrm{ft}$, were slightly deeper during the day than during the night, and were highly variable (table 9). When the reservoir elevation was less than $1,541 \mathrm{ft}$ during the spring study period, which occurred as the reservoir was filling in March and April, Chinook salmon showed a large diel difference in hourly depths; however, only eight tagged fish were present during that condition. Their individual mean hourly depths ranged from 16.0 to $139.0 \mathrm{ft}$, with mean values of $104.5 \mathrm{ft}$ during the day and $28.5 \mathrm{ft}$ during the night. Five of the eight fish present during that condition were much deeper during the day than during the night, two showed little or no diel change in depth, and two had insufficient data to make a determination.

Depths of steelhead were shallower and less variable than those of Chinook salmon during the spring study period (fig. 26). Steelhead were only present within $25 \mathrm{~m}$ of the dam when the reservoir elevation was greater than $1,541 \mathrm{ft}$. Their mean hourly estimated depths ranged from -0.3 to $7.1 \mathrm{ft}$ and were similar during the day and night for both elevation bins available.

There are position estimates of Chinook salmon over a wide range of reservoir elevations during the fall study period, but most fish were present only when the elevation was less than 1,525 ft. Their depths during the day were deeper than at night, but were highly variable (fig. 27, table 9). Their mean hourly depths ranged from 2.8 to $61.7 \mathrm{ft}$ when the reservoir elevation was at least $1,450 \mathrm{ft}$, and from 0 to $87.8 \mathrm{ft}$ when the elevation was less than $1,450 \mathrm{ft}$, however, the results for the latter condition were based on no more than 10 fish. 

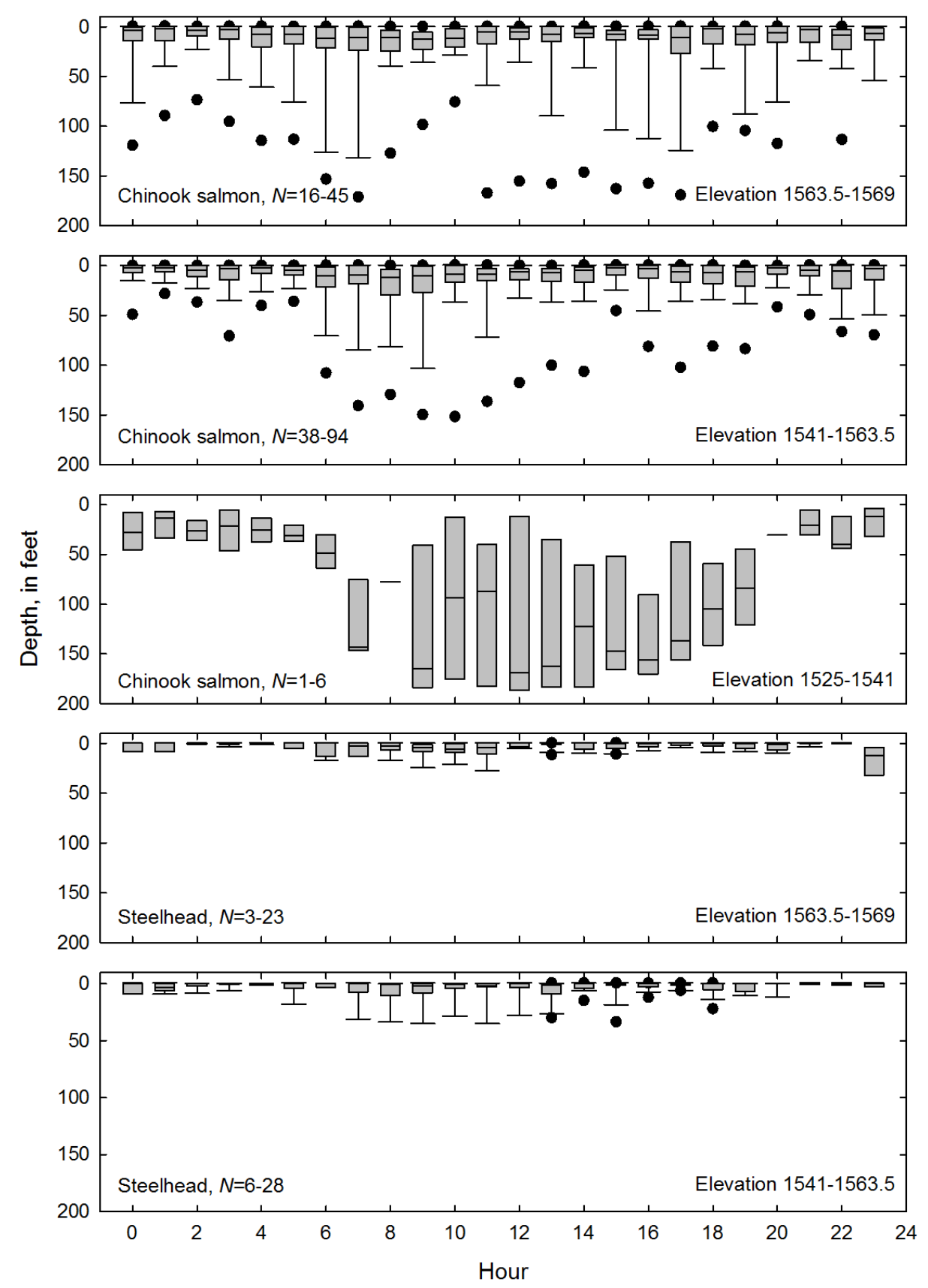

Figure 26. Boxplots of the hourly depths in feet of juvenile Chinook salmon and juvenile steelhead with position estimates within 25 meters of Detroit Dam, Oregon, during the 2012 spring study period. Data summarized are the median hourly depths of each fish present at the elevation ranges indicated. Boxes range from the 25th to the 75th percentiles with a line indicating the median, whiskers represent the 10th and 90th percentiles, and dots represent the 5th and 95th percentiles. Boxes without whiskers or dots contained insufficient data for them to be estimated. Sample sizes represent the number of fish $(N)$ in the hourly boxes. 
Table 9. Summary of the mean of the mean hourly depths of each fish with position estimates within 25 meters of Detroit Dam, Oregon, during the 2012 spring and fall study periods.

[Reservoir elevations are expressed in feet, $\geq$, greater than or equal to; < less than; sample size, the number of fish from which the depths were estimated; SE, standard error. Elevation bins without data are not shown]

\begin{tabular}{|c|c|c|c|c|c|c|}
\hline \multirow[b]{2}{*}{ Study season } & \multirow[b]{2}{*}{ Species } & \multirow[b]{2}{*}{ Reservoir elevation bin } & \multirow{2}{*}{$\begin{array}{c}\text { Diel } \\
\text { period }\end{array}$} & \multirow{2}{*}{$\begin{array}{l}\text { Sample } \\
\text { size }\end{array}$} & \multicolumn{2}{|c|}{ Depth } \\
\hline & & & & & Mean & SE \\
\hline \multirow[t]{6}{*}{ Spring } & Chinook & $\geq 1,563.5$ & Day & 120 & 15.2 & 26.7 \\
\hline & salmon & & Night & 94 & 9.0 & 18.6 \\
\hline & & 1,541 to $<1,563.5$ & Day & 195 & 18.5 & 33.4 \\
\hline & & & Night & 169 & 10.1 & 17.6 \\
\hline & & $<1,541$ & Day & 7 & 104.5 & 63.3 \\
\hline & & & Night & 8 & 28.5 & 11.7 \\
\hline \multirow[t]{4}{*}{ Spring } & Steelhead & $\geq 1,563.5$ & Day & 50 & 1.9 & 4.2 \\
\hline & & & Night & 33 & 0.6 & 3.1 \\
\hline & & 1,541 to $<1,563.5$ & Day & 60 & 3.0 & 7.3 \\
\hline & & & Night & 37 & 0.4 & 1.6 \\
\hline \multirow[t]{10}{*}{ Fall } & Chinook & 1,541 to $<, 1,563.5$ & Day & 11 & 31.7 & 22.2 \\
\hline & salmon & & Night & 15 & 17.3 & 15.5 \\
\hline & & 1,525 to $<1,541$ & Day & 47 & 44.4 & 23.9 \\
\hline & & & Night & 57 & 17.1 & 13.7 \\
\hline & & 1,500 to $<1,525$ & Day & 138 & 41.7 & 24.1 \\
\hline & & & Night & 151 & 10.0 & 14.4 \\
\hline & & 1,450 to $<1,500$ & Day & 177 & 31.8 & 20.6 \\
\hline & & & Night & 233 & 15.7 & 13.1 \\
\hline & & $<1,450$ & Day & 4 & 34.6 & 18.6 \\
\hline & & & Night & 6 & 12.9 & 9.6 \\
\hline
\end{tabular}



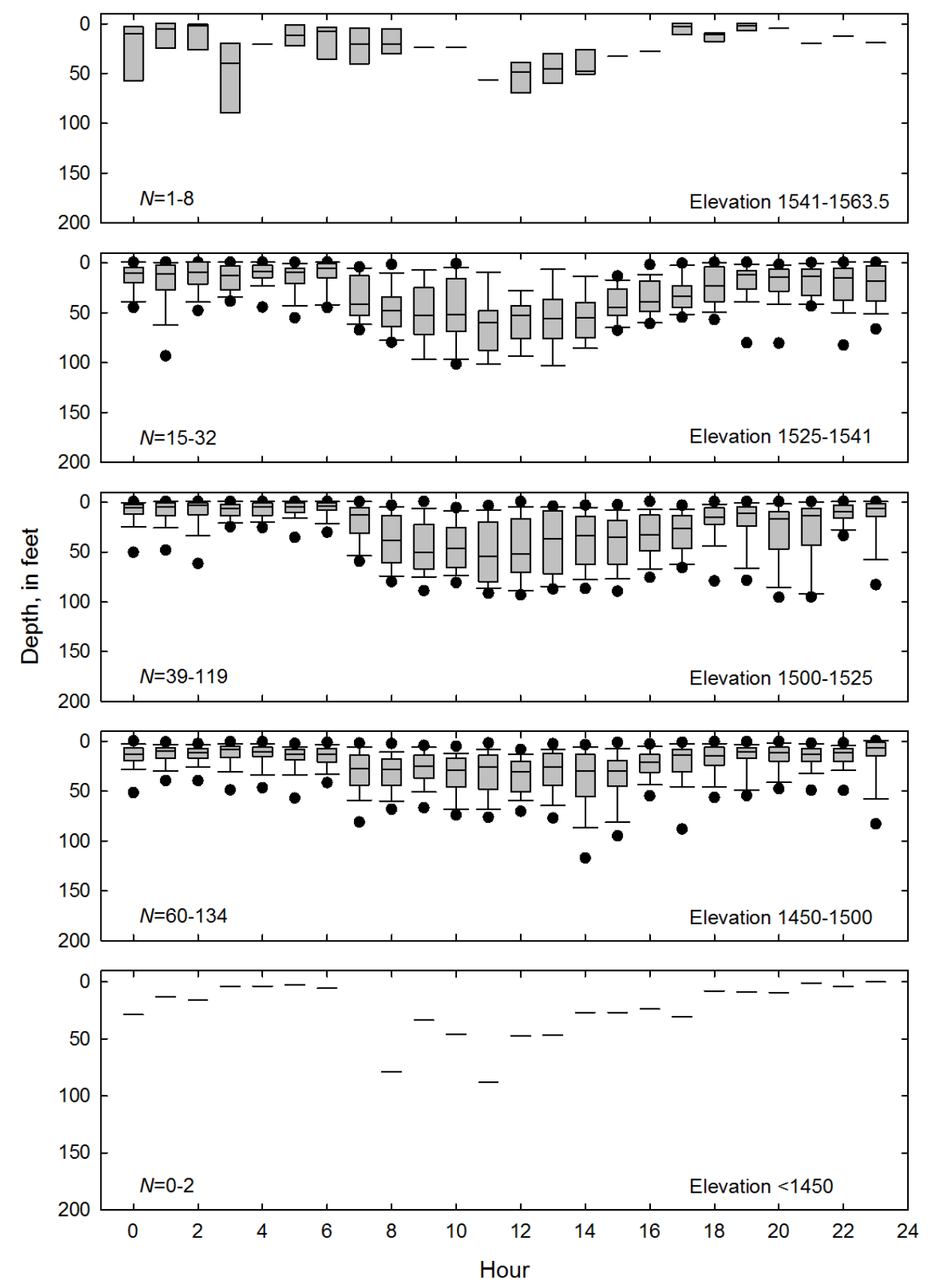

Figure 27. Boxplots of the hourly depths in feet of juvenile Chinook salmon with position estimates within 25 meters of Detroit Dam, Oregon, during the 2012 fall study period. Data summarized are the median hourly depths of each fish present at the elevation ranges indicated. Boxes range from the 25th to the 75th percentiles with a line indicating the median, whiskers represent the 10th and 90th percentiles, and dots represent the 5th and 95th percentiles. Incomplete boxes contained insufficient data. Sample sizes represent the number of fish $(N)$ in the hourly boxes. 


\section{Dam Passage}

Dam passage occurred primarily during periods of elevated discharge, and was most pronounced during the spring study period when spill occurred. Dates of dam passage ranged from March 20 to July 7, 2012, for Chinook salmon released in the spring; from April 25 to July 18, 2012, for steelhead released in the spring; and from September 14, 2012, to January 29, 2013, for Chinook salmon released in the fall. There were two peaks of Chinook salmon dam passage during the spring: between April 12 and 29, 2012, and between May 22 and June 16, 2012. Steelhead passed between April 25 and July 18, 2012. Most dam passage during the fall study period occurred from October 27 to December 20, 2012.

Of the fish released in the spring, 22 Chinook salmon and 6 steelhead were detected at downstream PIT tag interrogation sites at Willamette Falls in Oregon City or the trawl near the Columbia River estuary. Only one fish released in the fall was detected on a PIT tag interrogation site downstream. That Chinook salmon, released on September 13, 2012, was detected passing Detroit Dam within the life of the JSATS tag and was detected in the estuary trawl on March 13, 2013, $181 \mathrm{~d}$ after release.

Timing of assigned dam passage events varied by species. In the spring, 38 percent of the Chinook salmon passage events occurred during the day, but steelhead passage events occurred nearly equally in the day and night (51 and 49 percent, respectively; fig. 28). We do not know the time of passage for 81 Chinook salmon and 11 steelhead that passed the dam by an unknown passage route. All these fish were detected at the downriver detection array at Big Cliff Dam. Of these fish, 64 Chinook salmon and 7 steelhead were last detected in Detroit Reservoir during a power outage in early June that followed a fire at Detroit Dam; the detection equipment used to assign dam passage functioned intermittently during the power outage. The remaining 21 fish assigned an unknown passage route were last detected in the reservoir nearest to a route that was not operating based on the hourly operations data.

A total of 309 Chinook salmon and 88 steelhead were assigned passage during the spring study period. An additional five Chinook salmon passed the dam after the tag life cutoff (past the 90th percentile of expected tag life). We estimated that all fish passed the dam within $96.7 \mathrm{~d}$ after release. Therefore, during the spring period, 67.1 percent (314 of 468) of the Chinook salmon released were assigned dam passage, and 44.0 percent ( 88 of 200) of the steelhead released were assigned dam passage. Moreover, 64.9 percent (148 of 228) of the Chinook salmon and 51.4 percent (38 of the 78) of the steelhead tagged in the spring had passage events through known routes during the night.

Most tagged fish passed through the spillway during the spring study period and through the powerhouse during the fall study period. Dam passage of Chinook salmon detected at the log boom during the spring study period included 58.8 percent $(N=224)$ passing through spillway, 1.0 percent $(N$ $=4)$ passing through the powerhouse, and 21.3 percent $(N=81)$ passing through an undetermined route. Passage through undetermined routes was verified by detection downstream at Big Cliff Dam. Of the steelhead that were detected at the log boom, 72.9 percent $(N=78)$ passed through the spillway and 9.3 percent $(N=10)$ passed through undetermined routes. During the fall study period 19.2 percent $(N=73)$ of the Chinook salmon detected at the log boom passed through the powerhouse, 1.1 percent $(N=4)$ passed through the spillway, 0.3 percent $(N=1)$ passed through the regulating outlet, and 0.8 percent $(N=3)$ passed without an assigned route.

There were a total of 81 Chinook salmon passage events during the fall study period. Two more fish passed the dam after the tag life cutoff, 88 and $90 \mathrm{~d}$ after release. Therefore, during the fall study period, a total of 83 of the 514 Chinook salmon had passage events (16.1 percent). A total of 62 of 78 known passage events (79.5 percent) were at night during the fall study period. 

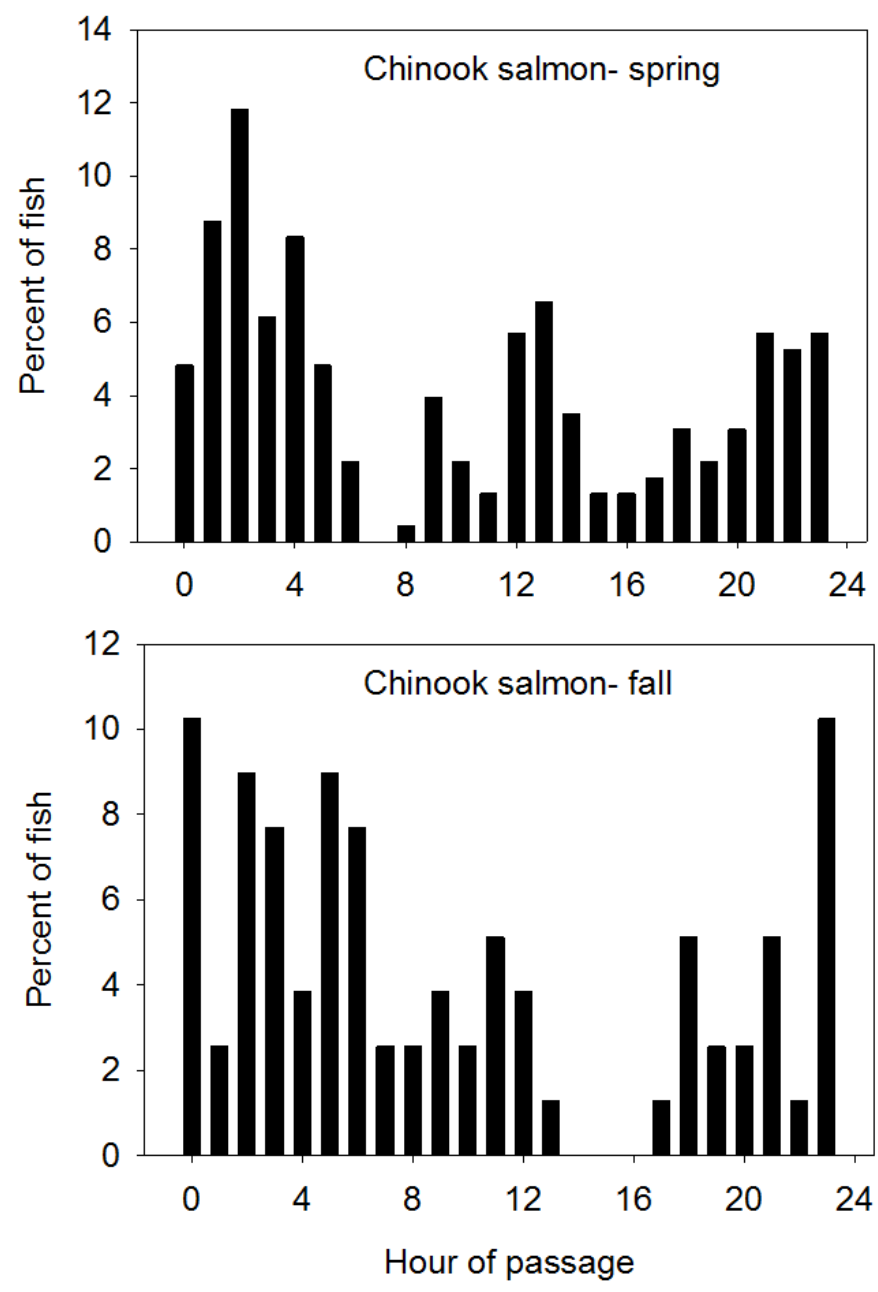

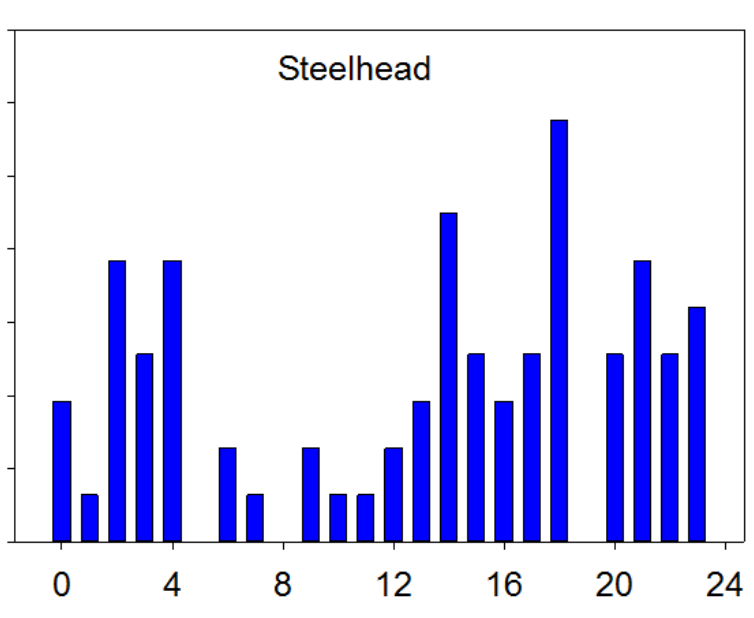

Hour of passage

Figure 28. Percentage of fish passing by hour at Detroit Dam, Oregon, during the 2012 spring and fall study periods.

\section{Reservoir and Dam Passage Efficiencies}

The primary difference between the season-wide behaviors of Chinook salmon and steelhead during the spring study period was the stream passage efficiency. A greater proportion of Chinook salmon than steelhead was detected in the reservoir following release. The estimated stream passage efficiencies were 0.880 for Chinook salmon and 0.615 for steelhead (table 10). The reservoir passage efficiencies were high during the spring study period $(0.870$ for steelhead and 0.925 for Chinook salmon). Dam passage efficiency was slightly higher than 0.800 for both species. Because of the preponderance of spillway passage during the spring study period, the spillway passage efficiencies and fish passage efficiencies for both species were 0.982 or greater. Route effectiveness was about 1.7 percent of fish per percent of water through the spillway and close to 0 percent of fish per percent of water through the powerhouse. During the fall study period, the stream passage efficiency of Chinook salmon was similar to that of Chinook salmon during the spring period, but most other estimated 
efficiencies were lower. The powerhouse was the most common route of passage during the fall study period because of the short period in which the reservoir elevation was high enough to enable use of the spillway. The dam passage efficiency during the fall study period $(0.213)$ was much lower than in the spring study period and the turbine passage efficiency (0.936) was much higher than in the spring study period. Season-wide passage efficiencies are representative of the suite of dam operations for which the data were collected, and varied with the various combinations of route operation. Spill effectiveness was 1.227 percent of fish per percent of water through the powerhouse, regulating outlet effectiveness was 0.059 , and turbine effectiveness was 1.263.

Table 10. Seasonal passage metric estimates, standard errors, and lower and upper 95-percent confidence intervals from the study of acoustic-tagged juvenile salmonids at Detroit Dam, Oregon, 2012.

[Sample size, number of tagged fish in the denominator of the estimate; SE, standard error; LCl, lower 95-percent confidence interval; UCl, upper 95-percent confidence interval; STRE, stream passage efficiency; RPE, reservoir passage efficiency; DPE, dam passage efficiency; FPE, fish passage efficiency; SPE, spillway passage efficiency; TURE, turbine passage efficiency]

\begin{tabular}{|c|c|c|c|c|c|c|c|c|}
\hline $\begin{array}{l}\text { Study } \\
\text { period }\end{array}$ & Species & Metric & $\begin{array}{c}\text { Sample } \\
\text { size }\end{array}$ & Estimate & SE & $\mathrm{LCl}$ & $\mathrm{UCl}$ & $\begin{array}{c}\text { Route } \\
\text { effectiveness }\end{array}$ \\
\hline \multirow[t]{12}{*}{ Spring } & Chinook & STRE & 468 & 0.880 & 0.015 & 0.848 & 0.907 & \\
\hline & salmon & RPE & 412 & 0.925 & 0.013 & 0.895 & 0.947 & \\
\hline & & DPE & 381 & 0.811 & 0.020 & 0.769 & 0.847 & \\
\hline & & FPE & 228 & 0.982 & 0.009 & 0.956 & 0.993 & \\
\hline & & SPE & 228 & 0.982 & 0.009 & 0.956 & 0.993 & 1.704 \\
\hline & & TURE & 228 & 0.018 & 0.009 & 0.007 & 0.044 & 0.041 \\
\hline & Steelhead & STRE & 200 & 0.615 & 0.034 & 0.548 & 0.682 & \\
\hline & & RPE & 123 & 0.870 & 0.030 & 0.799 & 0.918 & \\
\hline & & DPE & 107 & 0.822 & 0.037 & 0.739 & 0.883 & \\
\hline & & FPE & 78 & 1.000 & 0.000 & 0.953 & 1.000 & \\
\hline & & SPE & 78 & 1.000 & 0.000 & 0.953 & 1.000 & 1.734 \\
\hline & & TURE & 78 & 0.000 & 0.000 & 0.000 & 0.047 & 0.000 \\
\hline \multirow[t]{7}{*}{ Fall } & Chinook & STRE & 514 & 0.901 & 0.013 & 0.892 & 0.924 & \\
\hline & salmon & RPE & 463 & 0.821 & 0.018 & 0.783 & 0.853 & \\
\hline & & DPE & 380 & 0.213 & 0.021 & 0.175 & 0.257 & \\
\hline & & FPE & 78 & 0.064 & 0.028 & 0.028 & 0.141 & \\
\hline & & SPE & 78 & 0.051 & 0.025 & 0.020 & 0.125 & 1.227 \\
\hline & & ROE & 78 & 0.013 & 0.013 & 0.002 & 0.069 & 0.059 \\
\hline & & TURE & 78 & 0.936 & 0.028 & 0.859 & 0.972 & 1.263 \\
\hline
\end{tabular}


The dam passage efficiency (DPE) varied between spring and fall study periods when grouped by reservoir elevation. The spring study period only includes the three highest reservoir elevation groupings, but few fish passed in the lowest elevation range (1,541-1,525 ft; table 11). The lowest elevation range constituted only 10 percent of the spring study. The spring DPE estimates were near 0.6 for steelhead at both elevation ranges and near 0.7 for the highest elevation range for Chinook salmon and the highest elevation group for Chinook salmon. Steelhead were not present in the reservoir until April 23 and then readily passed through the spillway. Passage rates were lower in the fall study period, largely because of the short time the spillway was available. The highest DPE estimate was 0.240 in the less than 1,500-1,450 ft range, but represented four times as much time as any of the other elevation groups. No tagged fish passed the dam when the elevation was below $1,450 \mathrm{ft}$.

Table 11. Dam passage efficiency estimates, standard errors, and lower and upper 95-percent confidence intervals, by pool elevation, from the study of acoustic-tagged juvenile salmonids at Detroit Dam, Oregon, 2012.

[The dam passage efficiency metrics are not adjusted for the length of time each condition was present. Total time is limited to periods when tagged fish were present in the forebay. sample size, number of tagged fish in the denominator of the estimate; SE, standard error; LCl, lower 95-percent confidence interval; UCl, upper 95-percent confidence interval]

\begin{tabular}{ccccccccc}
\hline $\begin{array}{c}\text { Study } \\
\text { period }\end{array}$ & Species & $\begin{array}{c}\text { Reservoir elevation } \\
\text { bin }\end{array}$ & $\begin{array}{c}\text { Total time } \\
\text { (days) }\end{array}$ & Sample size & Estimate & SE & LCl & UCl \\
\hline Spring & Chinook & $<1,569$ to $1,563.5$ & 49.2 & 248 & 0.734 & 0.028 & 0.676 & 0.785 \\
& salmon & $<1,563.5$ to 1,541 & 95.4 & 295 & 0.420 & 0.029 & 0.365 & 0.477 \\
& & $<1,541$ to 1,525 & 14.3 & 11 & 0.273 & 0.134 & 0.098 & 0.566 \\
& & & & & & & & \\
& \multirow{3}{*}{ Steelhead } & $<1,569$ to $1,563.5$ & 49.2 & 72 & 0.611 & 0.058 & 0.496 & 0.715 \\
& & $<1,563.5$ to 1,541 & 95.4 & 70 & 0.629 & 0.058 & 0.512 & 0.732 \\
Fall & & & & & & & \\
& \multirow{4}{*}{ Chinook } & $<1,563.5$ to 1,541 & 12.8 & 35 & 0.171 & 0.064 & 0.081 & 0.327 \\
& salmon & $<1,541$ to 1,525 & 16.5 & 66 & 0.000 & 0.000 & 0.000 & 0.055 \\
& & $<1,525$ to 1,500 & 23.5 & 182 & 0.038 & 0.014 & 0.019 & 0.077 \\
& & $<1,500$ to 1,450 & 98.0 & 283 & 0.240 & 0.025 & 0.194 & 0.293 \\
\hline
\end{tabular}

\section{Effects of Selected Variables on Dam Passage Rates}

\section{Spring Study Period}

The effects of several factors on dam passage rates were assessed for the operating conditions with adequate numbers of fish passage events. In most of these analyses, the dependent variable was the rate of dam passage through all routes combined (spillway, powerhouse, or regulating outlet), whereas in the next section, factors affecting passage rates through only the spillway route are described. Passage rates through the powerhouse are also examined for data from the fall study period.

The first condition with suitable sample sizes for analysis was the weir spill condition occurring during part of April (table 12). Apart from that condition, the most common operating conditions during the spring study period were discharge through the powerhouse only, the spillway only, or the powerhouse plus spillway; the regulating outlet rarely was used. Of these conditions, only two had 
enough fish passage events to warrant analysis: the spillway only and powerhouse plus spillway conditions. Few tagged fish $(N=8)$ passed the dam during the powerhouse only condition, despite the condition occurring nearly 25 percent of the time.

Tagged Chinook salmon and steelhead were present in the area monitored near the dam at different times, so the analyses were divided accordingly. Chinook salmon were first detected within 25 $\mathrm{m}$ of the dam on March 20, 2012, at 11:42:46 p.m., and were last detected in that area on August 22, 2012, at 5:08:00 a.m. . Steelhead were first detected within $25 \mathrm{~m}$ of the dam on April 25, 2012 at 11:01:42 a.m., and were last detected in that area on July 24, 2012 at 2:37:00 a.m. The analyses, therefore, were based on data from (1) Chinook salmon during the weir spill condition and the 2 weeks that followed, (2) Chinook salmon over the entire season apart from the weir spill condition, and (3) Chinook salmon and steelhead when both species were present.

Table 12. Summary of the frequency of use of various operating conditions and the numbers of tagged fish with three-dimensional position estimates within 25 meters of the dam passing during each condition at Detroit Dam, Oregon, during the 2012 spring and fall study periods.

[Routes include powerhouse (PH), regulating outlet (RO), and spillway (SP) used together, singly, or not at all (All off)]

\begin{tabular}{|c|c|c|c|c|c|}
\hline \multirow[b]{3}{*}{ Route in use } & \multicolumn{3}{|c|}{ Spring study period } & \multicolumn{2}{|c|}{ Fall study period } \\
\hline & \multirow{2}{*}{$\begin{array}{l}\text { Percent of } \\
\text { total time }\end{array}$} & \multicolumn{2}{|c|}{ Passage events } & \multirow{2}{*}{$\begin{array}{l}\text { Percent of } \\
\text { total time }\end{array}$} & \multirow{2}{*}{$\begin{array}{c}\begin{array}{c}\text { Passage } \\
\text { events }\end{array} \\
\text { Chinook }\end{array}$} \\
\hline & & Chinook & Steelhead & & \\
\hline \multicolumn{6}{|c|}{ - } \\
\hline PH,SP,RO & 0.4 & 0 & na & 0.0 & 0 \\
\hline $\mathrm{PH}, \mathrm{SP}$ & 56.9 & 9 & na & 100.0 & 0 \\
\hline $\mathrm{PH}, \mathrm{RO}$ & 0.0 & 0 & na & 0.0 & 0 \\
\hline SP,RO & 1.5 & 0 & na & 0.0 & 0 \\
\hline $\mathrm{PH}$ & 0.0 & 0 & na & 0.0 & 0 \\
\hline SP & 41.3 & 17 & na & 0.0 & 0 \\
\hline RO & 0.0 & 0 & na & 0.0 & 0 \\
\hline All off & 0.0 & 0 & na & 0.0 & 0 \\
\hline Total & 100.0 & 26 & na & 100.0 & 0 \\
\hline \multicolumn{6}{|c|}{--.--- Condition-Not weir spill -.---.-- } \\
\hline PH,SP,RO & 0.0 & 0 & 0 & 0.0 & 0 \\
\hline $\mathrm{PH}, \mathrm{SP}$ & 20.6 & 43 & 24 & 3.6 & 0 \\
\hline $\mathrm{PH}, \mathrm{RO}$ & 0.0 & 0 & 0 & 40.6 & 55 \\
\hline SP,RO & 0.0 & 0 & 0 & 0.0 & 0 \\
\hline PH & 24.6 & 6 & 2 & 46.2 & 5 \\
\hline SP & 42.4 & 146 & 43 & 2.1 & 3 \\
\hline RO & 0.0 & 0 & 0 & 2.6 & 0 \\
\hline All off & 12.5 & 0 & 0 & 4.8 & 0 \\
\hline Total & 100.0 & 195 & 69 & 100.0 & 63 \\
\hline
\end{tabular}




\section{Weir Spill Condition}

The passage rate during the 2-week weir spill condition was compared to the rate during the following 2 weeks of the normal spill condition (April 20-May 4, 2012). There were 1 day and 25 night passage events during the weir spill condition and 4 day and 21 night passage events during the normal spill condition used for comparison. The full model included diel period, spill discharge, the spill type (weir or normal), and several 2-way interactions. The final model indicated that when spill discharge is controlled for, the passage rate during the weir condition was 3.114 times greater than the rate during the normal spill condition (table 13). Controlling for spillway discharge was important to adjust for differences in spillway discharge during the two conditions (weir spill mean 2,287 $\mathrm{ft}^{3} / \mathrm{s}$, range $1,225-$ $7,183 \mathrm{ft}^{3} / \mathrm{s}$; normal spill mean $3,102 \mathrm{ft}^{3} / \mathrm{s}$, range $915-5,702 \mathrm{ft}^{3} / \mathrm{s}$ ). Both conditions shared a common effect of diel period, with estimated passage rates at night being 4.330 times greater than those during the day. Note that the passage rate is the instantaneous rate of fish passage relative to the fish available to pass (those within $25 \mathrm{~m}$ of the dam at the time), which separates this method from many others. The interaction term of spill type and spill discharge indicated a moderate increase in passage rate with additional spill discharge during the normal spill condition (4.330 percent per $\left.100 \mathrm{ft}^{3} / \mathrm{s}\right)$, but no significant effect during the weir spill condition. All passage was through the spillway during each condition, but the spillway discharge was a greater percentage of the project discharge during the normal condition (mean 79.9 percent, range 34-100 percent) than during the weir condition (mean 70.9 percent, range 38-100 percent). The route effectiveness at the mean percent spill, therefore, was slightly greater during the weir spill condition (1.41) than during the normal spill condition (1.25).

Dam passage rates of Chinook salmon after the weir spill condition varied with the passage routes in operation. Dam operations during this condition included powerhouse and spillway together, powerhouse only, spillway only, and all routes off (table 12). All but 8 of the 264 passage events occurred when the powerhouse and spillway were operated together or when the spillway was operated singly, so the analyses were grouped into those two categories.

Table 13. Regression coefficients from analyses of the effects of selected variables on the rate of spillway passage of juvenile Chinook salmon within 25 meters of the upstream face of the area monitored at Detroit Dam, Oregon, during and 2-weeks after the weir spill condition in 2012 spring study period.

[Results are based on analysis of three-dimensional position estimates of tagged fish. DF, degrees of freedom; Parm= parameter; $\operatorname{Pr}>$ ChiSq, probability of a larger Chi-Square value under the hypotheses that the parameter estimate equals 0 ; $<$, less than. Results are based on a significance threshold of alpha $=0.10$. Significant variables include spillway discharge in 100 cubic feet per second increments (Spill.100cfs), Diel period $(1=$ day, $2=$ night $)$, type of spill $($ normal $=0$, weir $=1)$, and an interaction between type of spill and Spill.100cfs (Type*spill)]

\begin{tabular}{ccccrrrrr} 
Variable & DF & Parm. & $\begin{array}{c}\text { Standard } \\
\text { error }\end{array}$ & Chi-square & Pr $>$ ChiSq & Hazard ratio & $\begin{array}{r}\text { 95-percent hazard } \\
\text { ratio confidence limits }\end{array}$ \\
\hline Spill.100cfs & 1 & 0.042 & 0.015 & 7.887 & 0.0050 & 1.043 & 1.013 & 1.074 \\
Diel period & 1 & 1.465 & 0.375 & 15.289 & $<0.0001$ & 4.330 & 2.077 & 9.026 \\
Type of spill & 1 & 1.136 & 0.686 & 2.742 & 0.0978 & 3.114 & 0.812 & 11.947 \\
Type*spill & 1 & -0.040 & 0.020 & 3.772 & 0.0521 & 0.961 & 0.923 & 1.000 \\
\hline
\end{tabular}




\section{Powerhouse and Spillway Condition}

When the powerhouse and spillway were used together, passage rates of Chinook salmon during the spring study period were influenced by fish length, diel period, and spillway discharge. There were 191 tagged Chinook salmon with position estimates within $25 \mathrm{~m}$ of the dam during this condition. Spillway discharge was a supported factor but project discharge was not, a result likely owing to the small variation in powerhouse discharge relative to spillway discharge. The final model indicated that passage rates were greatest for large fish, at night, and at greater spillway discharges. The specific estimated effects for Chinook salmon within $25 \mathrm{~m}$ from the dam were a 39.5 percent increase in passage rate for each $10 \mathrm{~mm}$ increase in fork length, 6.561 times greater passage rate at night than during the day, and an increase in passage rate of 7.2 percent for each $100 \mathrm{ft}^{3} / \mathrm{s}$ increase in spillway discharge (table 14).

Results from analyses based on time periods when both Chinook salmon and steelhead were present in the monitored area were similar to those from Chinook salmon over the entire season. There were 155 tagged Chinook salmon and 64 tagged steelhead with position estimates within $25 \mathrm{~m}$ of the dam during this condition between April 25, 2012, and July 24, 2012. The data and models supported effects of fish length, diel period, project discharge, and spill discharge (table 14). The data and models did not support species-specific effects of fish size, diel period, or discharge. The estimated dam passage rates of each species increased by 26.9 percent for each $10 \mathrm{~mm}$ increase in fork length, were 7.893 times greater at night than during the day, and were 2.9 percent greater for each $100 \mathrm{ft}^{3} / \mathrm{s}$ increase in project

Table 14. Regression coefficients from analyses of the effects of selected variables on the rate of dam passage of juvenile Chinook salmon and juvenile steelhead within 25 meters of the upstream face of Detroit Dam, Oregon, when the powerhouse and spillway were operated together during the 2012 spring study period.

[Results are based on analysis of three-dimensional position estimates of tagged fish within 25 meters from the dam. DF, degrees of freedom; Parm= parameter; $\mathrm{Pr}>$ ChiSq, probability of a larger Chi-Square value under the hypotheses that the parameter estimate equals $0 ;<$, less than. Results are based on a significance threshold of alpha $=0.10$. Significant variables include project discharge in 100 cubic feet per second $\left(\mathrm{ft}^{3} / \mathrm{s}\right.$ ) increments (Proj.100cfs), spill discharge in $100 \mathrm{ft}^{3} / \mathrm{s}$ increments (Spill.100cfs), and fork length in 10-millimeter increments (Fl.10)]

\begin{tabular}{rlrrrrrrrr} 
Species & Variable & DF & Parm. & $\begin{array}{c}\text { Standard } \\
\text { error }\end{array}$ & $\begin{array}{c}\text { Chi- } \\
\text { square }\end{array}$ & Pr > ChiSq & $\begin{array}{c}\text { Hazard } \\
\text { ratio }\end{array}$ & $\begin{array}{c}\text { 95-percent hazard ratio } \\
\text { confidence limits }\end{array}$ \\
\hline Chinook & Fl.10mm & 1 & 0.333 & 0.122 & 7.436 & 0.0064 & 1.395 & 1.098 & 1.773 \\
& Diel period & 1 & 1.881 & 0.328 & 32.859 & $<0.0001$ & 6.561 & 3.448 & 12.482 \\
& Spill.100cfs & 1 & 0.070 & 0.018 & 14.533 & 0.0001 & 1.072 & 1.034 & 1.111 \\
& & & & & & & & & \\
Both $^{1}$ & Fl.10mm & 1 & 0.238 & 0.080 & 8.842 & 0.0029 & 1.269 & 1.085 & 1.485 \\
& Diel period & 1 & 2.066 & 0.265 & 60.731 & $<0.0001$ & 7.893 & 4.694 & 13.271 \\
& Proj.100cfs & 1 & 0.028 & 0.016 & 2.974 & 0.0846 & 1.029 & 0.996 & 1.062 \\
& & & & & & & & & \\
Both $^{1}$ & Fl.10mm & 1 & 0.237 & 0.078 & 9.208 & 0.0024 & 1.268 & 1.088 & 1.478 \\
& Diel period & 1 & 1.901 & 0.269 & 49.977 & $<0.0001$ & 6.693 & 3.951 & 11.339 \\
& Spill.100cfs & 1 & 0.063 & 0.019 & 10.556 & 0.0012 & 1.065 & 1.025 & 1.106 \\
\hline
\end{tabular}

${ }^{\mathrm{T}}$ Competing models restricted to date ranges when both species were present. 
discharge. An alternate model including spillway discharge in place of project discharge indicated that the passage rate increased by 6.5 percent for each $100 \mathrm{ft}^{3} / \mathrm{s}$ increase in spillway discharge, but was otherwise similar to the previous model. The model with spillway discharge was moderately more supported by the data than the model with project discharge, as indicated by the 4.6-unit difference in the AIC (not shown).

\section{Spillway Only Condition without Weir Spill}

Chinook salmon were present during the entire spring study period, but steelhead did not arrive near the dam until April 25, 2012. There were 252 tagged Chinook salmon with position estimates within $25 \mathrm{~m}$ of the dam during this condition over the entire spring study period. When both species were present during this condition, there were 217 tagged Chinook salmon and 74 tagged steelhead within $25 \mathrm{~m}$ of the dam.

Diel period and spill discharge were supported factors affecting dam passage rate of Chinook salmon within $25 \mathrm{~m}$ from the dam during this condition based on data from the entire study period. The passage rate at night was 3.818 times greater than during the day (table 15). The effect of a $100 \mathrm{ft}^{3} / \mathrm{s}$ increase in spill discharge was a 4.5 percent increase in dam passage.

Table 15. Regression coefficients from analyses of the effects of selected variables on the rate of dam passage of fish within 25 meters of the upstream face of the area monitored at Detroit Dam, Oregon, during the 2012 spring study period during the powerhouse off, spillway on condition without weir spill.

[Results are based on analysis of three-dimensional position estimates of tagged fish within estimated distances from the dam. DF, degrees of freedom; Parm., parameter; Pr $>$ ChiSq, probability of a larger Chi-Square value under the hypotheses that the parameter estimate equals $0 ;<$, less than. Results are based on a significance threshold of alpha $=0.10$. Significant variables include diel period $(1=$ day, $2=$ night), spill discharge in 100 cubic feet per second increments (Spill.100cfs), fork length in 10 millimeter increments $(\mathrm{Fl} .10)$, Species $($ Chinook $=1$, steelhead $=2)$, and various interactions $($ denoted by a $*$ in the variable name).]

\begin{tabular}{rlrccccccr} 
Species & Variable & DF & Parm. & $\begin{array}{c}\text { Standard } \\
\text { error }\end{array}$ & $\begin{array}{c}\text { Chi- } \\
\text { square }\end{array}$ & Pr $>$ ChiSq & $\begin{array}{c}\text { Hazard } \\
\text { ratio }\end{array}$ & $\begin{array}{c}\text { 95-percent hazard ratio } \\
\text { confidence limits }\end{array}$ \\
\hline Chinook & Diel period & 1 & 1.340 & 0.171 & 61.568 & $<0.0001$ & 3.818 & 2.732 & 5.336 \\
& Spill.100cfs & 1 & 0.044 & 0.009 & 23.957 & $<0.0001$ & 1.045 & 1.027 & 1.064 \\
& & & & & & & & & \\
Both $^{1}$ & Species & 1 & 1.207 & 0.558 & 4.676 & 0.0306 & 3.343 & 1.120 & 9.982 \\
& Diel period & 1 & 2.031 & 0.461 & 19.424 & $<0.0001$ & 7.625 & 3.090 & 18.818 \\
& Spill.100cfs & 1 & 0.039 & 0.008 & 23.388 & $<0.0001$ & 1.040 & 1.024 & 1.057 \\
& Species*diel & 1 & -0.697 & 0.352 & 3.917 & 0.0478 & 0.498 & 0.250 & 0.993 \\
\hline
\end{tabular}

${ }^{\mathrm{T}}$ Models restricted to a date range when both species were present. 
Diel period and spillway discharge were supported as factors affecting dam passage during the spillway only condition when both species were present. An interaction between species and diel period also was supported, indicating a difference in the effects of diel period for each species (table 15). The model indicated that the passage rate of steelhead was 3.343 times greater than the passage rate of Chinook salmon, and the passage rate of both species increased 4.0 percent for each $100 \mathrm{ft}^{3} / \mathrm{s}$ increase in spillway discharge. The interaction between species and diel period indicates a greater difference between day and night passage rates of Chinook salmon than of steelhead. The model predicted that the passage rate of Chinook salmon was 3.8 (95-percent confidence interval of 2.7-5.3) times greater at night than during the day, and that the rate of steelhead passage was 1.9 (95-percent confidence interval of 3.5-4.3) times greater at night than during the day.

\section{Fall Study Period}

The most common dam operating conditions during the fall study period were powerhouse only and powerhouse and regulating outlet operated together; these two conditions composed nearly 87 percent of the fall study period (table 12). As in the spring study period, few (5) tagged fish passed the dam during the powerhouse only condition, despite the common occurrence of the condition (46.2 percent of the study period). No tagged fish passed during the weir spill condition, which occurred for 2 $\mathrm{d}$ during the fall study period. Thus, analysis of factors affecting dam passage rates only was completed for the condition of the powerhouse and regulating outlet operating together, which occurred during 40.6 percent of the fall study period. A total of 282 Chinook salmon were positioned within $25 \mathrm{~m}$ from the dam beginning on October 19, 2012, at 8:00:00 a.m., and ending on February 3, 2013, at 5:00:00 p.m., during this condition.

\section{Powerhouse and Regulating Outlet Condition}

When the powerhouse and regulating outlet were used together during the fall study period, the passage rate of Chinook salmon was influenced by project discharge and forebay elevation, and their interaction term (table 16). Diel period was not supported as a factor of passage rate, although 45 of the 55 passage events during this condition occurred at night. The lack of support of the diel period variable is owing to the larger number of tagged fish near the dam at night than during the day, which resulted in a similar passage rate (number passing divided by number available) during day and night. The resulting model indicates that the passage rate during this condition is positively related to project discharge at high forebay elevations, but project discharge has little measurable effect on passage rates at low forebay elevations. For example, the predicted effect of a $100 \mathrm{ft}^{3} / \mathrm{s}$ increase in project discharge at a forebay elevation of 1,502 $\mathrm{ft}$ (the 90th percentile during this condition) is a 9.6-percent increase in passage rate (95-percent confidence interval of $1.4-19.3$ percent, $\left.P>\chi^{2}=0.0222\right)$, and at a forebay elevation of $1,452 \mathrm{ft}$ (the 10th percentile during this condition) is a statistically insignificant change of 1.1 percent (95-percent confidence interval of -5.2 to +3.1 percent, $P>\chi^{2}=0.5974$ ). This result suggests that as the forebay elevation is reduced, the passage rate becomes less affected by the project discharge. However, the passage rate increases as reservoir elevation decreases and the estimated passage rate at an elevation of 1,452 ft was 16.4 percent (95-percent confidence interval of 2.9-31.6 percent, $P>\chi^{2}=0.0158$ ) greater than the rate at the 1,502 -ft elevation.

We also examined the effects of route-specific and project discharges on passage rates through the powerhouse during this condition. Most passage events (53 of 55) were assigned a powerhouse route during this condition. One event was assigned to the regulating outlet, and we were unable to assign a route to the other. Powerhouse discharge was not a supported factor $(P=0.5417)$, but project discharge and regulating outlet discharge were supported (table 16). Models with project or regulating outlet 
discharges received similar support from the data, as indicated by AIC values within one unit (not shown). This result is due to the high correlation between project discharge and regulating outlet discharge (Pearson's $r=0.99, P<0.0001$ ). Total discharge and powerhouse discharge are weakly correlated in these data (Pearson's $r=0.14, P<0.0001$ ) because there is little variation in powerhouse discharge compared to regulating outlet discharge. The model with project discharge is similar to the model describing passage through any route, but the model based on regulating outlet discharge differs substantially from the others. The regulating outlet model predicts that the effect of increases in regulating outlet discharge, which increase powerhouse passage, are greatest when the elevation is high and diminish as the elevation decreases. Specifically, the model predicts a 9.8 percent increase (95percent confidence interval of $1.5-18.8$ percent, $P>\chi 2=0.0194)$ in powerhouse passage for every 100 $\mathrm{ft}^{3} / \mathrm{s}$ increase in regulating outlet discharge at an elevation of $1,502 \mathrm{ft}$, and no significant change in powerhouse passage at an elevation of $1,452 \mathrm{ft}(0.5$ percent change, 95 -percent confidence interval of 4.6 to 3.8 percent, $P>\chi 2=0.8057$ ). One explanation for this effect is that, at higher elevations, the regulating outlet discharge attracts fish to greater depths and they then pass through the powerhouse intakes prior to reaching the regulating outlet.

Table 16. Regression coefficients from analyses of the effects of selected variables on the rate of dam passage of juvenile Chinook salmon within 25 meters of the upstream face of the area monitored at Detroit Dam, Oregon, when the regulating outlet and powerhouse were operated together during the 2012 fall study period.

[Results are based on analysis of three-dimensional position estimates of tagged fish within estimated distances from the dam. DF, degrees of freedom; Parm., parameter; Pr $>$ ChiSq, probability of a larger Chi-Square value under the hypotheses that the parameter estimate equals $0 ;<$, less than. Results are based on a significance threshold of alpha $=0.10$. Significant variables include total project discharge in 100 cubic feet per second $\left(\mathrm{ft}^{3} / \mathrm{s}\right)$ increments (Proj.100cfs), regulating outlet discharge in $100 \mathrm{ft}^{3} / \mathrm{s}$ increments (Ro.100cfs), powerhouse discharge in $100 \mathrm{ft}^{3} / \mathrm{s}$ increments (Ph.100cfs), forebay elevation in 10 foot increments (fbelev.10), and various interactions (denoted by a * in the variable name)]

\begin{tabular}{|c|c|c|c|c|c|c|c|c|c|}
\hline \multirow{2}{*}{$\begin{array}{l}\text { Route } \\
\text { Either }\end{array}$} & \multirow{2}{*}{$\begin{array}{r}\text { Variable } \\
\text { Proj.100cfs }\end{array}$} & \multirow{2}{*}{$\frac{\mathrm{DF}}{1}$} & \multirow{2}{*}{$\begin{array}{l}\text { Parm. } \\
-3.092\end{array}$} & \multirow{2}{*}{$\begin{array}{c}\begin{array}{c}\text { Standard } \\
\text { error }\end{array} \\
1.608\end{array}$} & \multirow{2}{*}{$\begin{array}{c}\text { Chi-square } \\
3.696\end{array}$} & \multirow{2}{*}{$\frac{\mathrm{Pr}>\mathrm{ChiSq}}{0.0545}$} & \multirow{2}{*}{$\begin{array}{c}\begin{array}{c}\text { Hazard } \\
\text { ratio }\end{array} \\
0.045\end{array}$} & \multicolumn{2}{|c|}{$\begin{array}{l}\text { 95-percent hazard ratic } \\
\text { confidence limits }\end{array}$} \\
\hline & & & & & & & & 0.002 & 1.062 \\
\hline & Fbelev.10 & 1 & -1.329 & 0.567 & 5.486 & 0.0192 & 0.265 & 0.087 & 0.805 \\
\hline & Proj*fb & 1 & 0.021 & 0.011 & 3.743 & 0.0530 & 1.021 & 1.000 & 1.044 \\
\hline \multirow[t]{3}{*}{ Powerhouse $^{1}$} & Proj.100cfs & 1 & -2.930 & 1.610 & 3.312 & 0.0688 & 0.053 & 0.002 & 1.253 \\
\hline & Fbelev.10 & 1 & -1.250 & 0.568 & 4.851 & 0.0276 & 0.286 & 0.094 & 0.871 \\
\hline & Proj*fb & 1 & 0.020 & 0.011 & 3.361 & 0.0667 & 1.020 & 0.999 & 1.043 \\
\hline \multirow[t]{2}{*}{ Powerhouse $^{1}$} & Ph.100cfs & 1 & -0.103 & 0.169 & 0.372 & $0.5417^{2}$ & 0.902 & 0.647 & 1.257 \\
\hline & Fbelev.10 & 1 & -0.305 & 0.123 & 6.097 & 0.0135 & 0.737 & 0.579 & 0.939 \\
\hline \multirow[t]{3}{*}{ Powerhouse ${ }^{1}$} & Ro.100cfs & 1 & -2.875 & 1.546 & 3.457 & 0.0630 & 0.056 & 0.003 & 1.168 \\
\hline & Fbelev.10 & 1 & -0.795 & 0.313 & 6.436 & 0.0112 & 0.452 & 0.244 & 0.835 \\
\hline & $\mathrm{Ro} * \mathrm{fb}$ & 1 & 0.020 & 0.011 & 3.515 & 0.0608 & 1.020 & 0.999 & 1.041 \\
\hline
\end{tabular}

${ }^{\mathrm{T}}$ Alternative models.

${ }^{2} \mathrm{~A}$ non-significant effect. 
These results, in combination with the infrequent passage of tagged fish when the powerhouse was the only operating route, suggest that higher, or perhaps more variable, discharge than is provided by operation of the powerhouse alone was responsible for much of the dam passage of Chinook salmon during the fall study period. Only 5 of 58 powerhouse passage events occurred at project discharges of $2,579 \mathrm{ft}^{3} / \mathrm{s}$ or less, which was the maximum discharge passed through the powerhouse during the fall study period, despite that discharge range occurring for 56 percent of the period.

\section{Effects of Selected Variables on Spillway Passage Rates}

The rate of spillway passage was examined to determine how various factors affected it given the high percentage of dam passage through this route during the spring study period. The analysis was restricted to Chinook salmon because no steelhead were present within $25 \mathrm{~m}$ of the dam until April 25, 2012, which was after the weir spill condition. The spillway passage rate of Chinook salmon within 25 $\mathrm{m}$ of the dam was positively related to diel period (5.103 times higher at night than during the day), negatively related to forebay elevation, and positively related to spillway discharge, although an interaction between forebay elevation and spillway discharge also was supported $(P=0.0033$; table 17). The interaction indicates the predicted effect of spillway discharge increases with forebay elevation. For example, at an elevation of $1,545.0 \mathrm{ft}$, equal to $4 \mathrm{ft}$ above the spillway ogee crest, the effect of a $100 \mathrm{ft}^{3} / \mathrm{s}$ increase in spillway discharge is statistically non-significant ( 0.9 percent increase in spillway passage rate, 95-percent confidence interval of -0.02 to +0.03 percent, $P>\chi 2=0.4570$ ), but at the full conservation pool elevation of $1,563.5 \mathrm{ft}$, the rate increases by a statistically significant 6.4 percent (95percent confidence interval of 4.3-8.4 percent, $\left.P>\chi^{2}<0.0001\right)$. The model also predicts that, at the median spillway discharge of $1,485 \mathrm{ft}^{3} / \mathrm{s}$, the rate of spillway passage at a forebay elevation of $1,545.0 \mathrm{ft}$ is 1.6 times greater than the rate at an elevation of $1,563.5 \mathrm{ft}$.

Table 17. Regression coefficients from analyses of the effects of selected variables on the rate of spillway passage of juvenile Chinook salmon within 25 meters of the upstream face of the area monitored at Detroit Dam, Oregon, during the 2012 spring study period.

[Results are based on analysis of three-dimensional position estimates of tagged fish. DF, degrees of freedom; Parm., parameter; $\operatorname{Pr}>$ ChiSq, probability of a larger Chi-Square value under the hypotheses that the parameter estimate equals 0 ; < less than. Results are based on a significance threshold of alpha $=0.10$. Significant variables include Diel period $(1=$ day, 2 = night), spillway discharge in 100 cubic feet per second increments (Spill.100cfs), forebay elevation in 10-feet increments (Fbelev.10), and an interaction between Fbelev.10 and Spill.100cfs (Fb*spill)]

\begin{tabular}{llrrrrrrr}
\multicolumn{1}{c}{ Variable } & DF & Parm. & $\begin{array}{c}\text { Standard } \\
\text { error }\end{array}$ & Chi-square & Pr $>$ ChiSq & Hazard ratio & $\begin{array}{c}\text { 95-percent hazard ratio } \\
\text { confidence limits }\end{array}$ \\
\hline Diel period & 1 & 1.630 & 0.154 & 111.506 & $<0.0001$ & 5.103 & 3.771 & 6.905 \\
Fbelev.10 & 1 & -0.663 & 0.246 & 7.248 & 0.0071 & 0.515 & 0.318 & 0.835 \\
Spill.100cfs & 1 & -4.352 & 1.494 & 8.490 & 0.0036 & 0.013 & 0.001 & 0.241 \\
Fb*spill & 1 & 0.028 & 0.010 & 8.649 & 0.0033 & 1.029 & 1.009 & 1.048 \\
\hline
\end{tabular}




\section{Discussion}

Dam passage rates of the tagged Chinook salmon and steelhead at Detroit Dam during the spring and fall study periods were affected by dam operating condition, including which routes were used to pass water, as well as diel period, species, fish size, and dam discharge rate. Few tagged fish passed the dam when the powerhouse was the only route in operation, despite this condition occurring during nearly 25 percent of the spring study period and 46 percent of the fall study period. It is possible that the project discharge during this condition was too low to attract many Chinook salmon or steelhead into the penstock openings. The data and models supported a positive effect of discharge on dam passage rates, but few tagged fish passed the dam during project discharges less than the maximum observed powerhouse discharge of $2,198 \mathrm{ft}^{3} / \mathrm{s}$.

Most tagged fish passed the dam during the spillway only or spillway plus powerhouse condition during the spring study period and during the regulating outlet plus powerhouse condition during the fall study period. The most common route of passage was the spillway during the spring study period and the powerhouse during the fall study period when the spillway was rarely available. Numbers of tagged fish passing through the regulating outlet were not sufficient to enable evaluation of the factors affecting passage rates through that route. The highest passage rates during the spring study period were when the spillway was operating and the forebay elevation was close to the spillway ogee elevation of $1,541 \mathrm{ft}$ during the weir spill condition, followed by when the spillway was operated with discharge constrained by the Tainter gates in the typical manner. Spillway passage rates decreased as the forebay elevation increased and were estimated to be 1.6 times higher at a forebay elevation of 1,545.0 $\mathrm{ft}$ than at 1,563.5 $\mathrm{ft}$ (the full conservation pool elevation) at the median spillway discharge rate. Once the forebay elevation became lower than the spillway ogee during the fall study period, the passage rates decreased and the most common route of passage was the powerhouse. Passage rates during the fall study period were related to forebay elevation and both the regulating outlet discharge and total project discharge (which were highly correlated), but were statistically unrelated to the discharge through the powerhouse. This likely is a result of the small variation in powerhouse discharge relative to regulating outlet discharge. The estimated passage rate was 16 percent greater at an elevation of $1,452 \mathrm{ft}$ than at 1,502 ft, the 10th and 90th percentiles, respectively, of forebay elevation during the fall study period. Together with the relatively low effectiveness of the regulating outlet, these findings indicate that increasing discharge through the regulating outlet when the turbines are operating can increase passage through the powerhouse. This is consistent with the results of Khan and others (2012), who used fixed-location hydroacoustics to monitor fish distribution and passage at Detroit Dam over a year-long period beginning in February 2011. They estimated the efficiency of the regulating outlet to be 0.33 when it was operated together with the powerhouse and the spillway was not operating, indicating that about one-third of the fish passage occurred through the regulating outlet and two-thirds occurred through the powerhouse. The difference in locations of the openings to the two routes likely affected this outcome. The upper regulating outlet intakes are $63.6 \mathrm{ft}$ lower than the top of the penstock and at least $130 \mathrm{ft}$ away horizontally. In addition to the percentage of fish that pass, this effect has implications in terms of fish passage survival because the estimated direct survival of turbine passage was lower than the direct survival through the regulating outlets (Normandeau and Associates, Incorporated, 2010). 
There were several differences between the behavior and dam passage of Chinook salmon and steelhead. A lower percentage of steelhead were detected in the reservoir following release, and they took considerably longer to reach the reservoir than Chinook salmon. The fate of the fish that were never detected in the reservoir is unknown because no attempt was made to detect tagged fish in the tributaries. The undetected fish may have died, remained alive in the tributaries, or never migrated downstream to the most upstream detection array near Piety Island prior to the end of the transmitter life. The estimated detection probabilities of the equipment deployed in the reservoir were at or near 1.0, so it is unlikely that the fish migrated through the reservoir without being detected. Once in the reservoir, compared to Chinook salmon, steelhead made fewer trips throughout the reservoir, traveled faster from Piety Island to the log boom and from there to the dam, and had more direct paths near the dam. Steelhead showed little diel difference in depth when near the dam and were present at shallower depths than Chinook salmon. The dam passage rate of steelhead was estimated to be 3.343 times that of Chinook salmon when considering fish within $25 \mathrm{~m}$ of the dam when the spillway and powerhouse were operated together. This likely is related to differences in the depths of the two species.

The high passage rates of Chinook salmon during the weir spill condition suggest that a properly designed surface outlet could be a successful means of downstream passage of juvenile salmonids at Detroit Dam. We estimated Chinook salmon passage rates during the weir spill condition to be 3.1 times greater than during the conventional spill condition. This trend is consistent with results of studies of weir spill at other locations (Weiland and others, 2009; Beeman and others, 2010; Adams and others 2014). The route effectiveness during the weir spill condition (1.41) was lower than at sites with developed surface passage routes, which are commonly 5 or greater (Sweeney and others, 2007). The low effectiveness during the weir spill at Detroit Dam likely is affected by the high percentage of project discharge passing the weir spill route (mean 70.9 percent) compared to other sites $(9.8$ percent at Little Goose Dam in 2009; Beeman and others, 2010). Surface routes often pass a high percentage of fish at low discharge percentages, resulting in high effectiveness values.

Fish densities within $25 \mathrm{~m}$ of the dam were most concentrated near the dam during the spring study period when the spillway was operating, and were least concentrated near the dam in the fall study period when the spillway was not operating. When the reservoir elevation was sufficient to enable use of the spillway, the ogee of the spillway was much nearer to the depths of the tagged fish than the powerhouse, and most passage was through the spillway (the regulating outlet and spillway are not normally operated at the same time due to project guidelines). The spillway ogee is about $21 \mathrm{ft}$ deeper than the mean depths of steelhead during the day and night, and about 7 and $14 \mathrm{ft}$ shallower than the mean depths of Chinook salmon during the day and night, respectively, when the reservoir is at the full conservation pool $(1,563.5 \mathrm{ft})$. However, estimated fish depths were highly variable and the fish positions commonly were near the elevation of the spillway ogee. Among the keys to the successes of surface passage structures are the similarities in depths of the passage route and the fish, and the gradual acceleration to fish entrainment velocities (Haro and others, 1998; Sweeney and others, 2007). 
One useful diagnostic method for evaluating fish passage is to divide the fish passage process into a series of zones culminating with entrance and passage through the desired route (Castro-Santos and Haro, 2010). Sweeney and others (2007) generally described the zones upstream of the entrances of most surface fish passes in the Pacific Northwest as (1) Approach (330-33,000 ft), (2) Discovery (33$330 \mathrm{ft}$ ), and (3) Decision (0-33 ft). Our estimates of reservoir passage efficiencies and probabilities of presence suggest that Approach and Discovery were present for most tagged fish. It is also possible that the high probability of presence at the dam for fish that were within $200 \mathrm{ft}$ of it was a result of general milling behavior, and not due to a notable cue at the passage routes. The high degree of turning evident in the fish tracks and the low values of the percentages of fish concentrations near the dam suggest there was a lack of a Decision cue when the spillway was not operating and perhaps when it was operated together with the powerhouse. However, the success of the spillway in general as a passage route during the spring study period further supports the premise that a properly designed surface collector could work at Detroit Dam. Analysis of fish passage rates at the spillway indicated that the rate of passage was inversely related to the depth of water over the ogee, suggesting a shallow opening to a surface fish pass may be beneficial.

Our results and those of another evaluation of fish passage and distribution at Detroit Dam differ in several aspects. Based on fixed-location hydroacoustics, Khan and others (2012) noted that large proportions of juvenile-salmonid-sized fish were near the dam at depths of greater than $197 \mathrm{ft}$, peak passage occurred in winter, spillway passage abundance peaked in mid-morning and early afternoon, and the vertical distribution of fish near the dam was similar during the day and night. We detected very few tagged fish at depths greater than $197 \mathrm{ft}$ (one in particular that was assumed to be in a predator), which suggests that some of the targets they reported may not have been Chinook salmon. We also found diel differences in the depths of Chinook salmon and that passage rates of Chinook salmon and steelhead at night were several times higher than passage rates during the day. Khan and others (2012) hypothesized that their results may have been influenced by the presence of juvenile kokanee salmon (Oncorhynchus nerka) stocked in the reservoir for a sport fishery and suggested further study of the topic. We agree that their data may be from more than one species and that their results do not necessarily represent juvenile Chinook salmon. There were no juvenile steelhead in Detroit Reservoir during their study, although rainbow trout (Oncorhynchus mykiss) had been stocked in the reservoir for a sport fishery. The relative passage percentages through the various routes are not comparable between the two studies because the dam operating conditions differed greatly between studies. For example, the spillway was used for nearly the entire spring study period in this study, and it was used infrequently during the study of Khan and others (2012). One of the primary advantages of the hydroacoustic method over the individual animal telemetry method we used is the difference in sample sizes. Our data were limited to several hundred known individuals, whereas Khan and others (2012) estimated they detected dam passage of more than 210,000 fish.

This report describes fish released during the first of 2 years to study the movements and dam passage of acoustic-tagged juvenile salmonids at Detroit Reservoir and Dam. The second year of data collection was complete at the time of this report. The goal of the study is to provide information to inform decisions about the design of future downstream passage alternatives and how various operating conditions affect the downstream passage of juvenile salmonids given the existing dam configuration. The available data support the premise that a properly designed surface outlet could be a viable passage route for Chinook salmon and steelhead at Detroit Dam. Fish passage rates with the existing dam configuration were greatest when the spillway was operating and were lowest when the powerhouse was the only route operated; the latter result may be related to the relatively low magnitude and variability in discharge during that condition. 


\section{Acknowledgments}

This study was completed with assistance from many people and organizations. The Oregon Department of Fish and Wildlife, and staff at the Willamette Hatchery and Oregon State University and cooperators on the Wild Fish Surrogate Study provided the study fish. Staff at Marion Forks Hatchery provided space and facilities for us to hold and tag the fish. U.S Army Corps of Engineers staff at Detroit and Big Cliff dams were instrumental in coordinating our activities to install equipment and monitor the tagged fish near the dams, as were Scott Fielding, David Griffith, and Bob Wertheimer at the Portland District office. The U.S. Forest Service at Detroit Lake provided boat storage and moorage space. Our administrative and science colleagues at the Columbia River Research Laboratory (particularly Noah Adams, Scott Brewer, Brian Ekstrom, Theresa Liedtke, Gary Rutz, Matt Sholtis, and Nick Swyers) contributed greatly to this study. The report benefited from reviews by Chris Holbrook, Fred Monzyk, and Mike Parsley. This study was funded by the U.S. Army Corps of Engineers under contract W66QKZ13045978.

\section{References Cited}

Adams, N.S., Plumb, J.M. , Perry, R.W. , and Rondorf, D.W., 2014, Performance of a surface bypass structure to enhance juvenile steelhead passage and survival at Lower Granite Dam, Washington: North American Journal of Fisheries Management, v. 34, p. 576-594.

Allison, P.D., 1995, Survival analysis using SAS $®$ : A practical guide: Cary, North Carolina, SAS Institute Inc., 292 p.

Bainbridge, R., 1960, Speed and stamina of three fish: Journal of Experimental Biology, v. 37, p. 129153.

Beeman, J.W., Braatz, A.C., Hansel, H.C., Fielding, S.D., Haner, P.V., Hansen, G.S., Shurtleff, D.J., Sprando, J.M., and Rondorf, D.W., 2010, Approach, passage, and survival of juvenile salmonids at Little Goose Dam, Washington: Post-construction evaluation of a temporary spillway weir, 2009: U.S. Geological Survey Open-File Report 2010-1224, 101 p., http://pubs.usgs.gov/of/2010/1224/.] Beeman, J.W., Hansel, H.C., Hansen, A.C., Haner, P.V., Sprando, J.M., Smith, C.D., and Evans, S.D., 2013, Behavior and dam passage of juvenile Chinook salmon at Cougar Reservoir and Dam, Oregon, March 2011-February 2012: U.S. Geological Survey Open-File Report 2013-1079, 48 p.

Bhat, U.N., and Miller, G.K., 2002, Elements of applied stochastic processes: Hoboken, New Jersey, Wiley, $461 \mathrm{p}$.

Burnham, K.P., and Anderson, D.R., 2002, Model selection and multimodel inference-A practical information-theoretic approach: New York, Springer-Verlag, 488 p.

Castro-Santos, T., and Haro, A., 2003, Quantifying migratory delay-A new application of survival analysis methods: Canadian Journal of Fisheries and Aquatic Sciences, v. 60, p. 986-996.

Castro-Santos, T., and Haro, A., 2010, Fish guidance and passage at barriers, in Domenici, P., and Kapoor, B.G., eds., Fish locomotion-An eco-ethological perspective: Enfield, New Hampshire, Science Publishers, p. 62-89.

Castro-Santos, T., and Perry, R., 2012, Time-to-event analysis as a framework for quantifying fish passage performance, in Adams, N.S., Beeman, J.W., and Eiler, J.H., eds., Telemetry Techniques-A user's guide for fisheries research: Bethesda, Maryland, American Fisheries Society, p. 427-452.

Cormack, R.M., 1964, Estimates of survival from the sighting of marked animals: Biometrika, v. 51, nos. 3-4, p. 429-438. 
Haro, A., Odeh, M., Noreika, J., and Castro-Santos, T., 1998, Effect of water acceleration on downstream migratory behavior of Atlantic salmon smolts and juvenile American shad at surface bypasses: Transactions of the American Fisheries Society, v. 127, p. 118-127.

Hosmer, D.W., and Lemeshow, S., 1999, Applied survival analysis-Regression modeling of time to event data: New York, Wiley, 386 p.

Johnson, G.E., Hedgepeth, J.B., Skalski, J.R., and Giorgi, A.E., 2004, A Markov chain analysis of fish movements to determine entrainment zones: Fisheries Research, v. 69, p. 349-358.

Jolly, G.M., 1965, Explicit estimates from capture-recapture data with both death and immigrationstochastic model: Biometrika, v. 52, nos. 1-2, p. 225-247.

Khan, F., Royer, I.M., Johnson, G.E., and Ham, K.D., 2012, Hydroacoustic evaluation of juvenile salmonid passage and distribution at Detroit Dam, 2011: Pacific Northwest National Laboratory report PNNL-21577, 76 p.

Klein, F.W., 1978, Hypocenter location program HYPOINVERSE, 1, User's guide to versions 1, 2, 3, 4: U.S. Geological Survey Open-File Report 78-694, 103 p.

Lee, W.H.K., and Stewart, S.W., 1981, Principles and applications of microearthquake networks: New York, Academic Press, 293 p.

Menke, W., 1989, Geophysical data analysis_-Discrete inverse theory: San Diego, Academic Press, 291 p.

Mesa, M., Phelps, J., and Weiland, L. K., 2008, Spring swimming performance of wild bull trout (Salvelinus confluentus): Northwest Science, v. 82, p. 1-6.

McMichael, G.A., Eppard, M.B., Carlson, T.J., Carter, J.A., Ebberts, B.D., Brown, R.S., Weiland, M., Ploskey, G.R., Harnish, R.A., and Deng, Z.D., 2010, The juvenile salmon acoustic telemetry system-A new tool: Fisheries, v. 35, no. 1, p. 9-22.

Moser, T.J., 1991, Shortest path calculation of seismic rays: Geophysics, v. 56, p. 59-67.

National Oceanic and Atmospheric Administration, 2008, Endangered Species Act section 7(a)(2) consultation biological opinion and Magnuson-Stevens Fishery Conservation and Management Act essential fish habitat consultation - Consultation on the Willamette River Basin Flood Control Project, National Oceanic and Atmospheric Administration Fisheries Log Number:

FINWR12000/02117, June 11, 2008. [Also available online at http://www.nwr.noaa.gov/SalmonHydropower/Willamette-Basin/Willamette-BO.cfm.]

Normandeau and Associates, Incorporated, 2010, Estimates of direct survival and injury of juvenile rainbow trout (Oncorhynchus mykiss) passing spillway, turbine, and regulating outlet at Detroit Dam, Oregon: Draft report of Normandeau and Associates, Incorporated, Drumore, Pennsylvania, to U.S. Army Corps of Engineers, contract W912EF-08-D-0005 task order DT01, $182 \mathrm{p}$.

Seber, G.A.F., 1965, A note on the multiple-recapture census: Biometrika, v. 52, nos. 1-2, p. 249-259.

Seber, G.A.F., 1982, The estimation of animal abundance and related parameters. New York, Macmillan, $654 \mathrm{p}$.

Speisberger, J.L., and Fristrup, K.M., 1990, Passive location of calling animals and sensing of their acoustic environment using acoustic tomography: American Naturalist, v. 135, p. 107-153.

Surgical Protocols Steering Committee, 2011, Surgical protocols for implanting JSATS transmitters into juvenile salmonids for studies conducted for the U.S. Army Corps of Engineers: Report prepared by Surgical Protocols Steering Committee for U.S. Army Corps of Engineers, Portland, Oregon.

Sweeney, C.E., Giorgi, A.E., Johnson, G.E., Hall, R., and Miller, M., 2007, Surface bypass program comprehensive review report: ENSR Corporation document number 09000-399-0409, 494 p. 
Taylor, E.B., and McPhail, J.D., 1985, Variation in burst and prolonged swimming performance among British Columbia populations of coho salmon, Oncorhynchus kisutch: Canadian Journal of Fisheries and Aquatic Sciences, v. 42, p. 2029-2033.

Titzler, P.S., McMichael, G.A., and Carter, J.A., 2010, Autonomous acoustic receiver deployment and mooring techniques for use in large rivers and estuaries: North American Journal of Fisheries Management, v. 30, p. 853-859.

Webb, P.A., 1978, Temperature effects on acceleration of rainbow trout (Salmo gairdneri): Journal of the Fisheries Research Board of Canada, v. 35, p. 1417-1422.

Weiland, M.A, Ploskey, G.R., Hughes, J.S., Deng, Z., Fu, T., Monter, T.J., Johnson, G.E., Khan, F., Wilberding, M.C., Cushing, A.W., Zimmerman, S.A., Faber, D.M., Durham, R.E., Townsend, R.L., Skalski, J.R., Kim, J., Fischer, E.S., and Meyer, M.M., 2009, Acoustic telemetry evaluation of juvenile salmonid passage and survival at John Day Dam with emphasis on the prototype surface flow outlet, 2008: Report PNNL-18890, Pacific Northwest National Laboratory, Richland, Washington, $259 \mathrm{p}$.

White, G.C., and Burnham, K.P., 1999, Program MARK-Survival estimation from populations of marked animals: Bird Study, v. 46 (supp.), p. 120-138. 


\section{Appendix A. Results of Analyses of Movement Probabilities from Fish Released into Tributaries of Detroit Reservoir, Oregon, 2012.}

Table A1. Movement probabilities of juvenile Chinook salmon and steelhead moving from one detection array to an adjacent detection array, given the previous array location within Detroit Reservoir, Oregon, during the 2012 spring study period.

\begin{tabular}{|c|c|c|c|c|c|c|c|c|c|c|}
\hline & & & \multicolumn{8}{|c|}{ Probability of moving from current array to adjacent array } \\
\hline \multirow{6}{*}{$\begin{array}{l}\text { 음 } \\
\text { 등 }\end{array}$} & \multirow{6}{*}{ 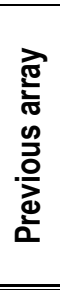 } & & 2 to 4 & 2 to 1 & 4 to 6 & 4 to 2 & 6 to 8 & 6 to 4 & 8 to 6 & 8 to Pass \\
\hline & & 1 & 0.63 & 0.37 & & & & & & \\
\hline & & 2 & & & 0.62 & 0.38 & & & & \\
\hline & & 4 & 0.50 & 0.50 & & & 0.72 & 0.28 & & \\
\hline & & 6 & & & 0.40 & 0.60 & & & 0.79 & 0.21 \\
\hline & & 8 & & & & & 0.77 & 0.23 & & \\
\hline \multirow{5}{*}{ 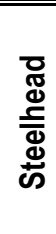 } & \multirow{5}{*}{ 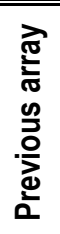 } & 1 & 0.76 & 0.24 & & & & & & \\
\hline & & 2 & & & 0.72 & 0.28 & & & & \\
\hline & & 4 & 0.50 & 0.50 & & & 0.72 & 0.28 & & \\
\hline & & 6 & & & 0.31 & 0.69 & & & 0.77 & 0.23 \\
\hline & & 8 & & & & & 0.62 & 0.38 & & \\
\hline
\end{tabular}

Table A2. Movement probabilities of juvenile Chinook salmon moving from one detection array to an adjacent detection array, given the previous array location within Detroit Reservoir, Oregon, during the 2012 fall study period.

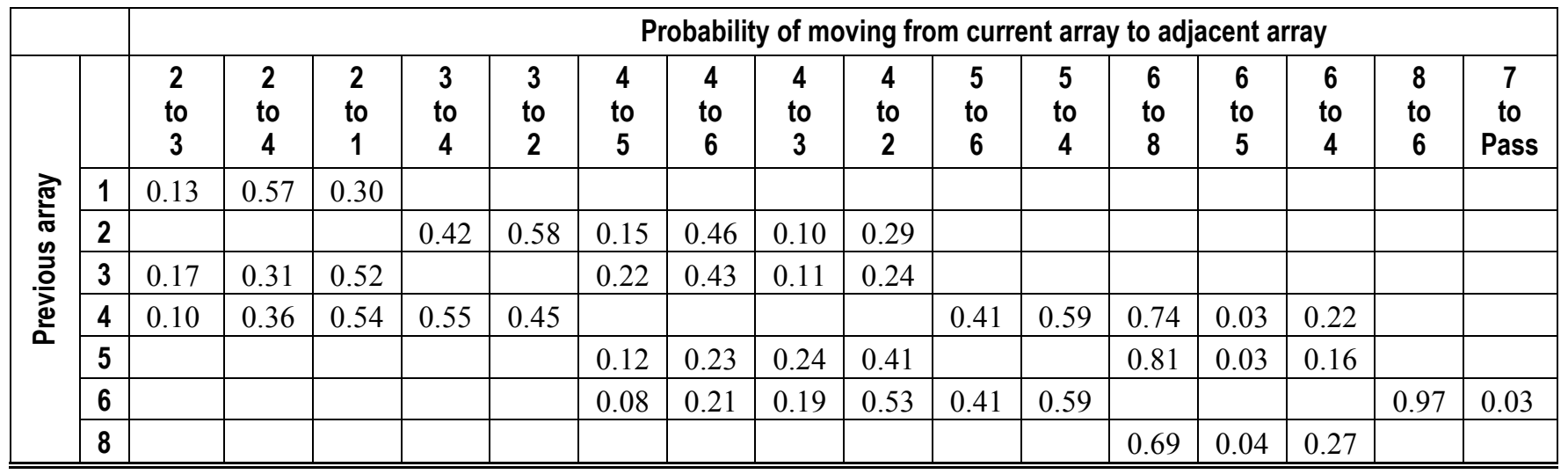


Table A3. Markov model comparisons for juvenile Chinook salmon and steelhead in Detroit Reservoir, Oregon during the 2012 spring study period.

[Models assuming a one-step Markov chain movement from one array to an adjacent array were compared to a full model that assumed a two-step Markov Chain. NS indicates no model support for the one-step model compared to the full two-step model, CS indicates considerable support]

\begin{tabular}{|c|c|c|c|c|c|c|}
\hline \multirow[b]{3}{*}{ Model } & \multicolumn{3}{|c|}{ Chinook salmon } & \multicolumn{3}{|c|}{ Steelhead } \\
\hline & & Ita & Model & & & Model \\
\hline & AIC & AIC & Support & AIC & AIC & Support \\
\hline Full model & 63.08 & 0.00 & & 54.90 & 0.00 & \\
\hline M124=M424; M421=M121 & 84.71 & 21.63 & NS & 86.48 & 31.58 & NS \\
\hline $\mathrm{M} 246=\mathrm{M} 646 ; \mathrm{M} 242=\mathrm{M} 642$ & 120.26 & 57.18 & NS & 127.71 & 72.81 & NS \\
\hline $\mathrm{M} 468=\mathrm{M} 868 ; \mathrm{M} 464=\mathrm{M} 864$ & 66.02 & 2.94 & $\mathrm{CS}$ & 59.24 & 4.34 & $\mathrm{CS}$ \\
\hline
\end{tabular}

Table A4. Markov model comparisons for juvenile Chinook salmon in Detroit Reservoir, Oregon, during the 2012 fall study period.

[Models assuming a one-step Markov chain movement from one array to an adjacent array were compared to a full model that assumed a two-step Markov Chain. NS indicates no model support for the one-step model compared to the full two-step model, and CS indicates considerable support, and SS indicates substantial support]

\begin{tabular}{lccc}
\multicolumn{1}{c}{ Model } & AlC & Delta & Model \\
& AlC & Support \\
\hline Full model & 244.242 & 0.000 & \\
M123=M323=M423 & 257.880 & 13.638 & NS \\
M124=M324=M424 & 419.014 & 174.772 & NS \\
M121=M321=M421 & 465.559 & 221.317 & NS \\
M234=M434, M232=M432 & 256.109 & 11.867 & NS \\
M245=M345=M545=M645 & 297.597 & 53.355 & $\mathrm{NS}$ \\
M246=M346=M546=M646 & 474.191 & 229.949 & $\mathrm{NS}$ \\
M243=M343=M543=M643 & 316.621 & 72.379 & $\mathrm{NS}$ \\
M242=M342=M542=M642 & 619.685 & 375.443 & $\mathrm{NS}$ \\
M456=M656, M454=M654 & 242.242 & -2.000 & $\mathrm{SS}$ \\
M468=M568=M868 & 267.243 & 23.181 & $\mathrm{NS}$ \\
M465=M565=M865 & 243.657 & -0.585 & $\mathrm{SS}$ \\
M464=M564=M864 & 263.984 & 19.742 & $\mathrm{NS}$ \\
\hline
\end{tabular}


Publishing support provided by the U.S. Geological Survey Publishing Network, Tacoma Publishing Service Center

For additional information contact:

Director, Western Fisheries Research Center

U.S. Geological Survey

6505 NE 65th Street

Seattle, Washington 98115

http://wfrc.usgs.gov/ 


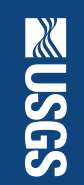

ס

(])

콕

옹

울

(1)

인

윽

总

뭉

흥.

里

윽.

름

망

I

$\frac{0}{9}$

귱

옹

$\stackrel{\vec{D}}{\vec{A}}$ 